$$
\begin{aligned}
& \text { AECEIVED A4CM-ZR-0012 } \\
& J_{N} 2.2 \text { 1099 } \\
& O_{S T}
\end{aligned}
$$

Rocketdyne Propulsion \&x Power DOE Operations

\title{
Annual Site
}

Environmental Report

1997

DISTRIBUTION OF THIS DOCUMENT IS UIULMTED

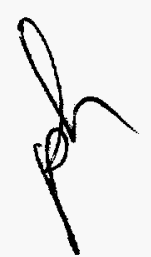

MASTER 



\section{DISCLAIMER}

This report was prepared as an account of work sponsored by an agency of the United States Government Neither the United States Government aor any agency thereof, nor any of their employees, makes any warranty, express or implied, or assumes any legal liability or responsibility for the accuracy, completeness, or usefulness of any information, apparatus, product, or process disclosed, or represents that its use would not infringe privately owned rights. Reference berein 10 any specific commercial product, process, or service by trade name. tradernark, manufacturer, or otherwise does not necessarily constitute or imply its endorsement. recommendation, or favoring by the United States Government or any ageacy thereof. The views and opinions of authors expressed hereio do not necessarily state or reflect those of the. United States Government or any agency thereof. 


\section{DISCLAIMER}

Portions of this document may be illegible in electronic image products. Images are produced from the best available original document. 
ROCKETDYNE PROPULSION \& POWER DOE OPERATIONS

ANNUAL SITE

ENVIRONMENTAL REPORT

1997

Prepared by the Staff of Rocketdyne Propulsion \& Power

Edited by K. S. Robinson

November 23, 1998 


\section{Site Environmental Report Reader Survey}

To Our Readers:

The 1996 Annual Site Environmental Report publishes the results of environmental monitoring in support of DOE-sponsored programs at Rocketdyne's Santa Susana Field Laboratory and DeSoto sites, and documents our compliance with federal, state, and local environmental regulations. In providing this information, our goal is to give our readership - regulators, scientists, and the public - a clear understanding of our environmental actividies, the methods we use, how we can be sare our results are accurate, the stanus of our programs, and significant issues affecting our programs.

It is important that the information we provide is easily understood, of interest, and communicates Rocketdyne's efforts to protect human heatth and minimize our impact on the environment. We would like to know from you whether we are successful in achieving these goals. Your comments are appreciated and will help us to improve our communications.

1. Is the writing

too concise?

D too concise?

too wordy?

$\square$ uneven?

Q just right?

2. Is the technical content

a yes

too wordy?

uneven?

D just right?

3. Is the text easy to understand?

$\square$ too technical $\square$ too detailed

other:

If you selected "no," is it:
4. Is the report comprehensive?

(please identify issues you believe are missing in the comments section)

5. Do the illustrations help you understand the text better?

Are the figures understandable?

Are there enough?

Toofew?

Too many?

6. Are the data tables of interest?

Would you prefer short summaries of data trends instead?

7. Is the background information sufficient?

Are the methodologies described reasonably understandable?

8. Are the glossaries and appendices useful?
Yes No

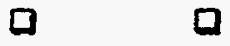

$\begin{array}{ll}a & \square \\ 0 & \square \\ 0 & a \\ \square & \square \\ \square & \square\end{array}$

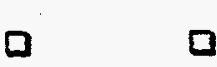

口 $\square$

$\square$

Other comments:

Please return this survey to Radiation Safety -M/S T487, Rocketdyne Propulsion \& Power, 6633 Canoga Avenue, Canoga Park, CA 91309

\section{OPTIONAL INFORMATION}

Name: Occupation:

Address: 



\section{CERTIFICATE OF ACCURACY}

I certify that I have personally examined and am familiar with the information submitted herein and, based on inquiry of those individuals immediately responsible for preparing this report, I believe that the submitted information is true, accurate, and complete.

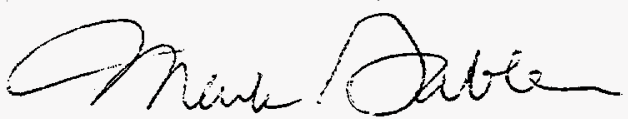

Mark J. Gabler, Director

Energy Technology Engineering Center

November 23, 1998 


\section{Department of Energy \\ Oakland Operations Office \\ 1301 Clay Street \\ Oakland, California 94612-5208 \\ OEC 1998}

Distribution:

SUBJECT: 1997 Site Environmental Report (SER) for the Energy Technology Engineering Center (ETEC)

This report, prepared by the Rocketdyne Division of Boeing North American, Inc. (RD) for the U.S. Department of Energy, Oakland Operations Office (DOE-OAK), provides a comprehensive summary of the DOE environmental protection activities at the Energy Technology Engineering Center (ETEC) for calendar year 1997. Site Environmental Reports (SERs) are prepared annually for all DOE sites with significant environmental activities, and distributed to relevant external regulatory agencies and other interested organizations and individuals.

To the best of my knowledge, this report accurately summarizes the results of the 1997 environmental monitoring and restoration program at ETEC for the DOE. This assurance can be made based on DOE-OAK and RD review of the SER, and quality assurance protocols applied to monitoring and data analyses at ETEC.

A reader survey form is provided with the SER to provide comments or suggestions for future versions of the report. Your response is appreciated. Questions or comments regarding this report may also be made directly to DOE-OAK, by contacting Steve Black of the Environment, Safety, and Health Division at (510) 637-1595, or by mail to the address above.

Sincerely,

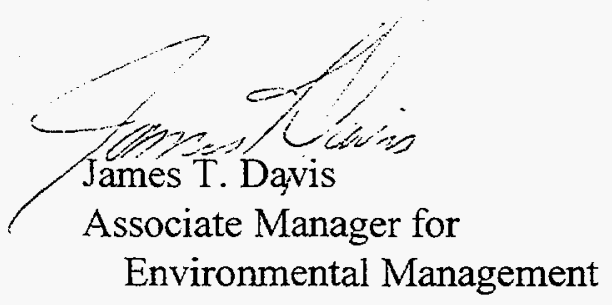




\section{CONTENTS}

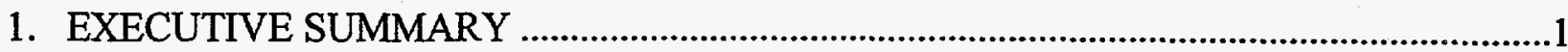

2. INTRODUCTION

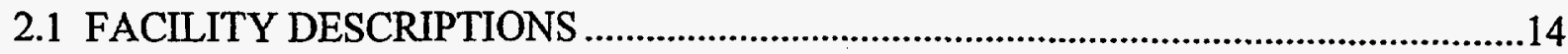

2.1.1 Santa Susana Field Laboratory Site ................................................................14

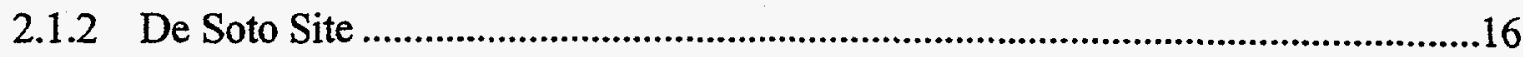

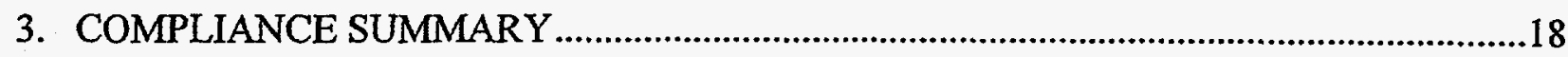

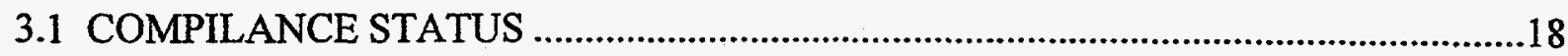

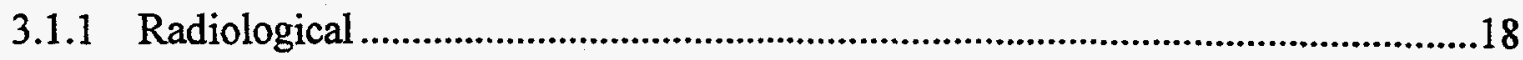

3.1.2 Comprehensive Environmental Response, Compensation, and Liability Act.......20

3.1.3 Resource Conservation and Recovery Act...........................................................21

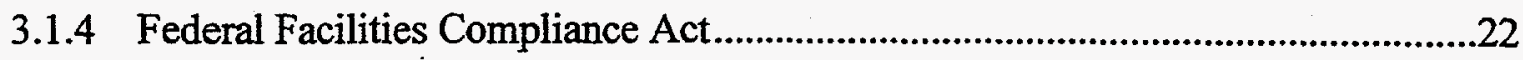

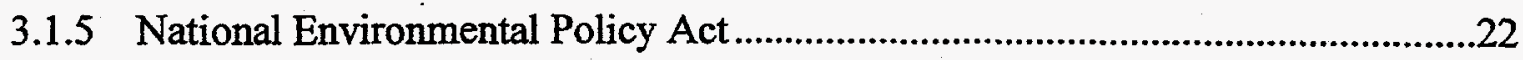

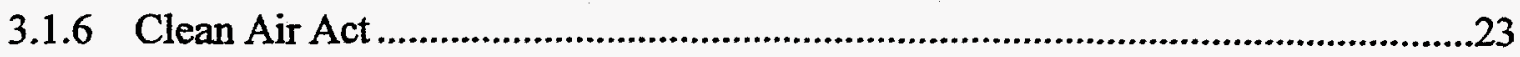

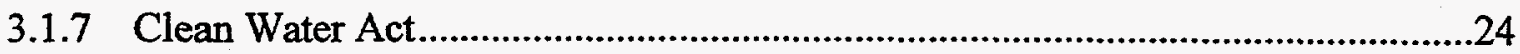

3.1.8 Former Sodium Disposal Facility Closure Order ………......................................26

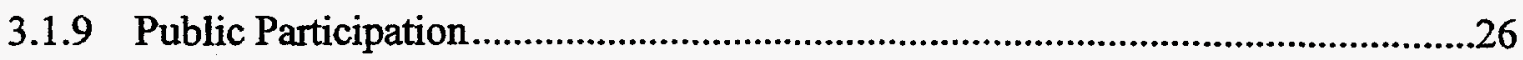

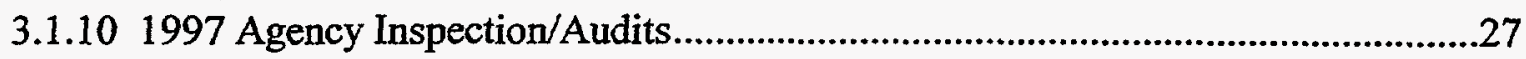

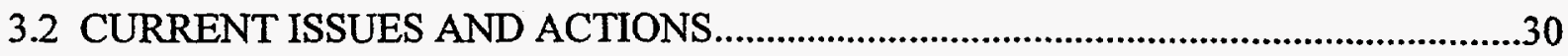

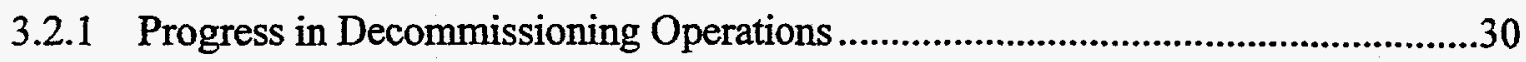

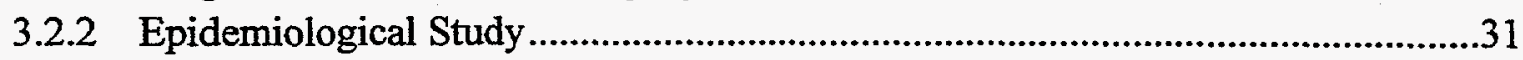

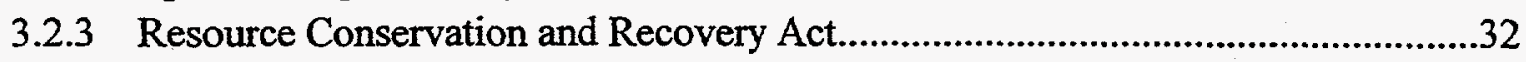

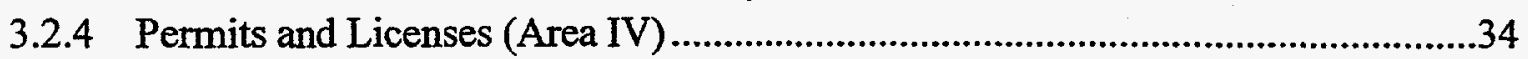

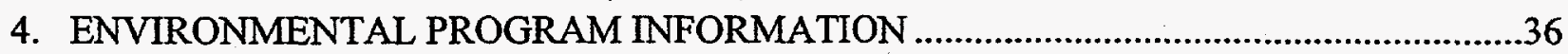

4.1 ROCKETDYNE ENVIRONMENTAL PROTECTION AND REMEDIATION.............36

4.2 ENVIRONMENTAL MONITORING PROGRAM …...............................................38

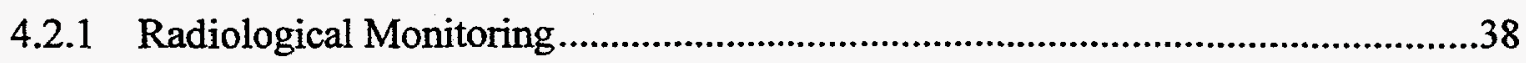

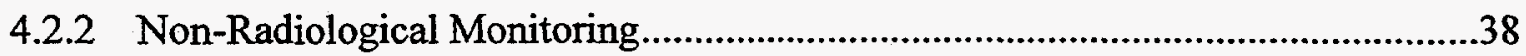

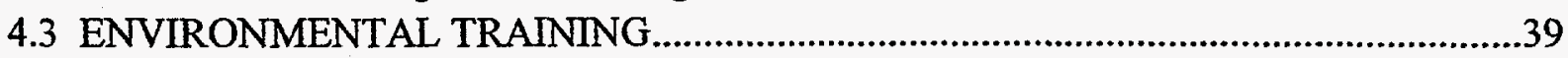

4.4 WASTE MNIMIZATION AND POLLUTION PREVENTION ...................................40

4.4.1 Program Planning and Development ...................................................................40

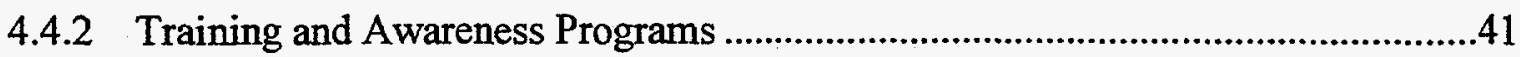

4.4.3 Waste minimization and Pollution Prevention Activities......................................42

4.4.4 Tracking and Reporting System..........................................................................43

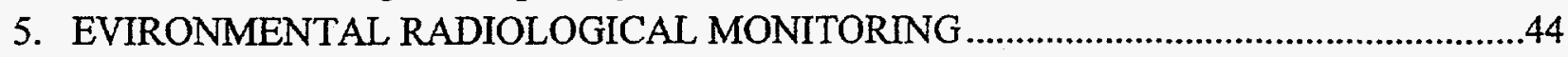

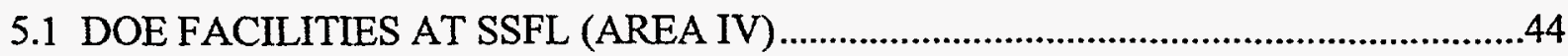

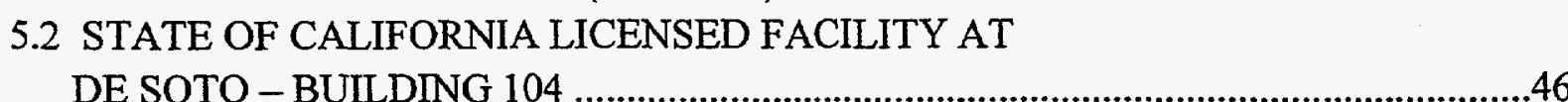

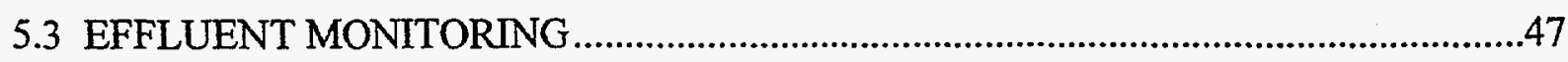

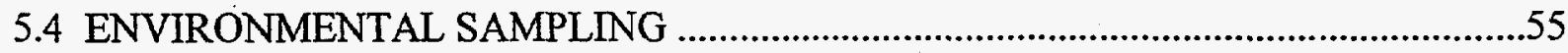

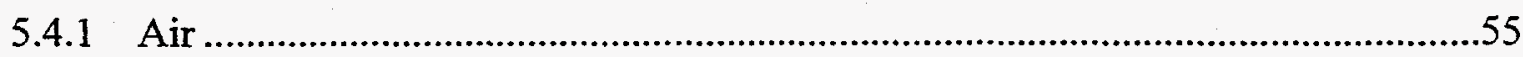


5.4.2. Groundwater

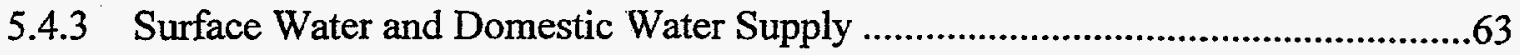

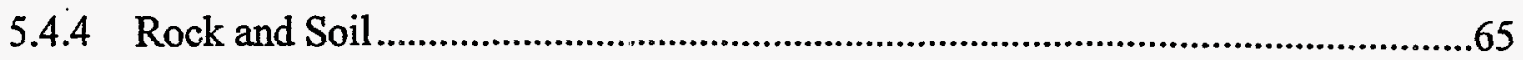

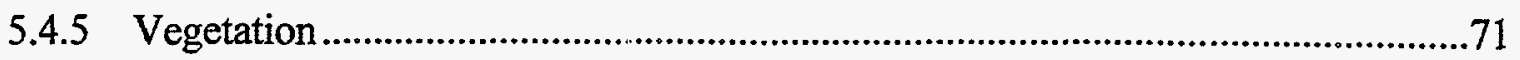

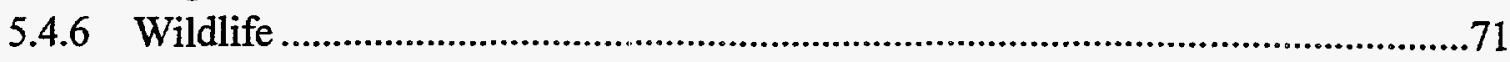

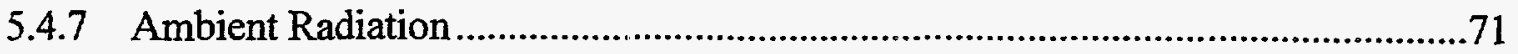

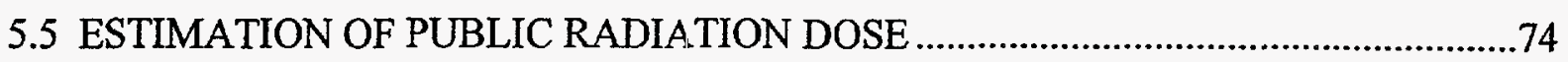

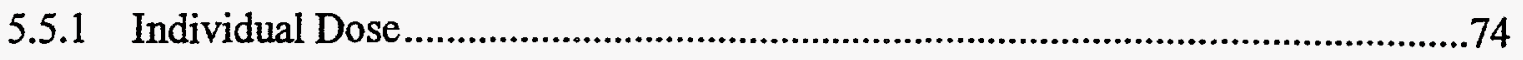

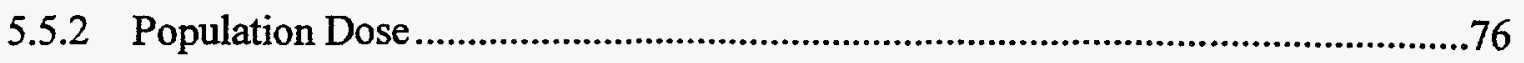

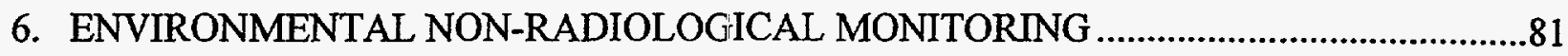

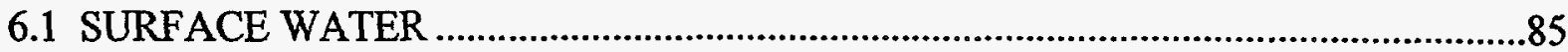

6.2 AIR

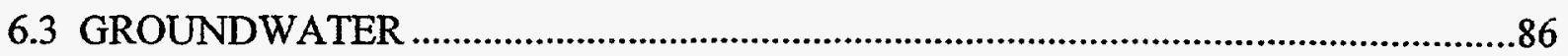

7. ENVIRONMENTAL MONITORING PROGRAM QUALITY CONTROL ........................90

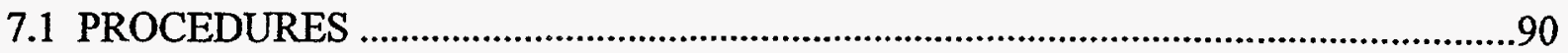

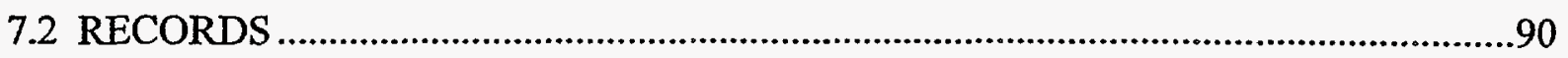

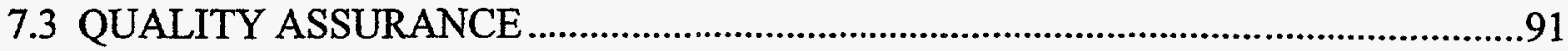

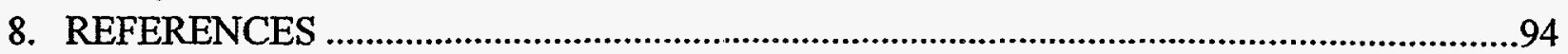

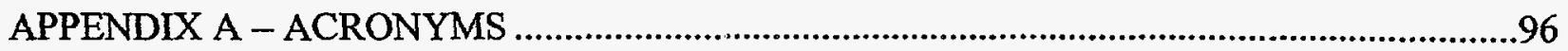

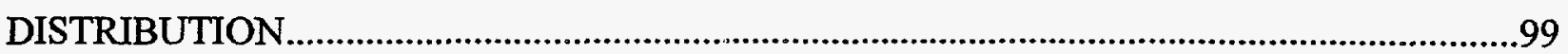


3-1. Summary of ETEC Compliance with EPCRA in 1997

3-2. 1997 Agency Inspection/Visits Related to Environmental Remediation

3-3. SSFL Area IV Current Underground Storage Tanks .........................................................35

5-1. Atmospheric Effluents to Uncontrolled Areas ..............................................................50

5-2. Filtered and Ambient Air Radioactivity Concentrations - 1997 ......................................54

5-3. Annual Average Radioactivity Concentrations of Atmospheric Effluents - 1997 ............55

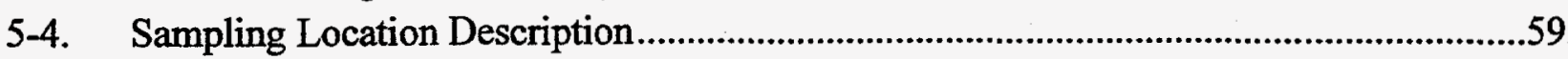

5-5. Ambient Air Radioactivity Data - 1997.....................................................................61

5-6. Radioactivity in Groundwater at SSFL - 1997 ...............................................................63

5-7. NPDES Discharge Radioactivity Data for Northwest Slope Monitoring - 1997 .............64

5-8. Domestic Water Supplies Radioactivity Data ...................................................................65

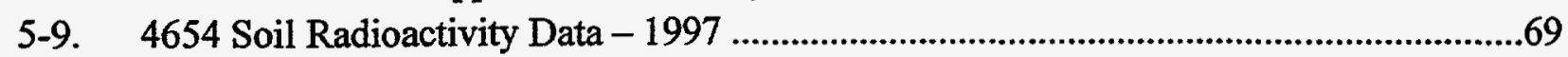

5-10. Hot Laboratory Soil Radioactivity Data -1997 .................................................................70

5-11. De Soto and SSFL Ambient Radiation Dosimetry Data - 1997 ......................................73

5-12. Public Exposure to Radiation and Radioactivity from DOE Operations at SSFL - 199775

5-13. Public Exposure to Radiation and Radioactivity from Licensed Operations at De Soto1997. 


\section{FIIGURES}

2-1. Santa Susana Field Laboratory Site Arrangement .....................................................5

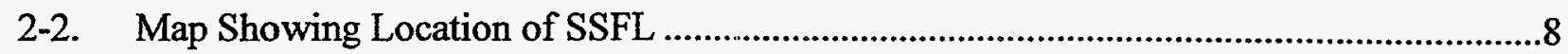

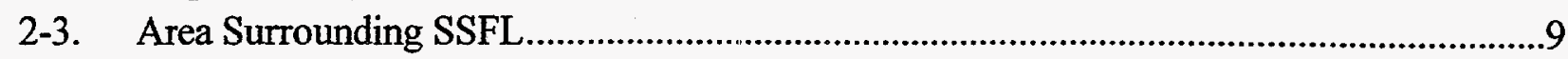

2-4. Rocketdyne Propulsion \& Power - Santa Susana Field Laboratory Site, Area IV ...........10

2-5. Map of Santa Susana Field Laboratory Area IV Facilities .............................................11

2-6. Rocketdyne Propulsion \& Power - De Soto Site...........................................................13

5-1. Map of De Soto Monitoring Stations...........................................................................57

5-2. Map of Santa Susana Field Laboratory Area IV Sampling Stations.................................58

5-3. Tritium Concentration in Water from Well RD-34A.................................................62

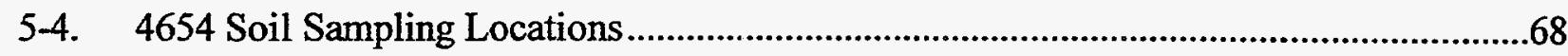

5-5. Probability Distribution of Cs-137 Activity in Soil Samples 4654 Soil Areas ................69

5-6. Probability Distribution of Cs-137 Activity in Soil Samples from the Hot Laboratory Soil Areas ...................................................................................................................70

5-7. Census Tract Boundaries (1990) within 10 miles of SSFL (individual tracts are identified

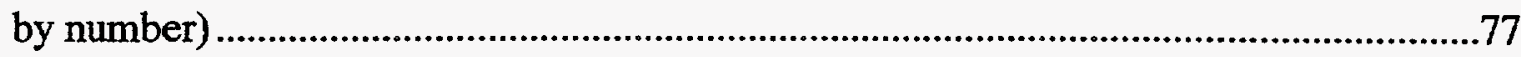

5-8. SSFL Site Centered Demography to $8 \mathrm{~km}$ (1990), Showing Number of Persons Living in Each Grid (daytime employment for SSFL) ................................................................78

5-9. SSFL Site Centered Demography to $16 \mathrm{~km}$ (1990), Showing Number of Persons Living in Each Grid ........................................................................................................79

5-10. SSFL Site-Centered Demography to $80 \mathrm{~km}$ (1990), Showing Number of Persons Living in Each Grid (heavily populated areas are shown by shading) .....................................80

6-1. Locations of Surface Water Runoff Collectors Along Northwest Boundary of SSFL, Area

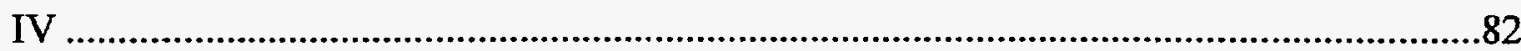

6-2. Locations of Wells Used in Groundwater Management Program ....................................84

6-3. TCE Occurrences in Groundwater at SSFL, Area IV .................................................88

7-1. Quality Assessment Program Results for QAP-XLVI and QAP-XLVII.......................92 


\section{EXECUTIVE SUMMARY}

This Annual Site Environmental Report for 1997 concentrates on the environmental conditions related to work performed for the Department of Energy (DOE) at Area IV of the Rocketdyne Santa Susana Field Laboratory (SSFL) and De Soto facilities. In the past, these operations included development, fabrication, and disassembly of nuclear reactors, reactor fuel, and other radioactive materials, under the Atomics International Division (AI). Other activities included the operation of large scale liquid metal facilities for the testing of liquid metal fast breeder components at the Energy Technology Engineering Center (ETEC), a government owned company operated, test facility within Area IV. AI was merged into Rocketdyne in 1984 and many of the AI functions were transferred to existing Rocketdyne departments. All nuclear work was terminated in 1988 , and subsequently, all radiological work has been directed toward decontamination and decommissioning (D\&D) of the previously used nuclear facilities and associated site areas. Large scale D\&D activities of the sodium test facilities began in 1996.

The results of the radiological monitoring program for the calendar year of 1997 continue to indicate that there are no significant releases of radioactive material from Rocketdyne sites. The atmospheric discharge of radioactive materials in ventilation exhausts, airborne dust from remediation activities, and direct radiation exposure are the only potential exposure pathways to the general public from the Rocketdyne radiological cleanup and waste packaging operations. All radioactive wastes are processed for disposal at DOE disposal sites and other sites licensed for radioactive waste. Liquid radioactive wastes are not released into the environment and do not constitute an exposure pathway. Groundwater and surface water in the environment are sampled and analyzed to ensure detection of any radioactivity. Neither groundwater nor surface water is used as a source of drinking water or agricultural irrigation. Except for low concentrations of tritium, well below Federal and State drinking water standards, in some of the groundwater wells and extracted from a soil sample, only naturally occurring radioactivity has been found in this water. The groundwater wells that show tritium, and the area where tritium was extracted from the soil, are associated with an excavated test reactor facility (Building 4010).

Radioactivity in the facility ventilation exhaust effluents, and in the ambient air, is analyzed to assess any impact of the remaining radiological operations on the public and the environment. Little radioactivity is dispersed by these operations and very little is released to the environment, because of highly efficient air filtration systems. Only small amounts of nonnatural radioactivity are found in the exhaust effluents. Except for localized areas of facility and soil contamination, only naturally occurring radioactivity can be detected in soil and vegetation samples. Some areas of soil contamination were exposed to the wind and potential airborne suspension has been estimated for these sources.

Calculated radiation doses to the public, due to airborne releases and direct radiation, are a factor of thousands to millions of times lower than the applicable limits as well as the naturally existing background levels. These hypothetical doses are too small to permit direct measurement. Conservative calculations provide upper-limit estimates of possible doses to the public. The radiation dose to a member of the public (maximally exposed individual) due to direct radiation is estimated to be less than $0.0002 \mathrm{mrem}$. This can be compared with the annual dose from natural sources of about 
300 mrem. The maximum public dose due to airborne radioactivity released from SSFL facilities is estimated to be less than $0.0000027 \mathrm{mrem}$. For the De Soto facility, the maximum public dose due to airborne radioactivity is $0.0000049 \mathrm{mrem}$ and from direct radiation, $0.054 \mathrm{mrem}$. Both these doses are far below the annual dose from natural airborme activity, about $200 \mathrm{mrem}$.

The non-radiological monitoring program has increased in recent years, with more extensive sampling of the groundwater at the Santa Susana Field Laboratory. Nine new wells were installed in Area IV during 1993 and 1994 to characterize the hydrogeology and water quality of known groundwater chemical contamination, horizontally and vertically, and in relation to the potential source areas. Three new wells were installed in Area IV in 1994 for extraction and treatment of degraded groundwater bringing the total to 45. No new wells were drilled between 1995 and 1997 . Two hundred twenty seven (227) onsite wells installed by Rocketdyne and 16 offsite private wells (including the 45 for Area IV) were included in the 1997 groundwater monitoring program for the entire SSFL to characterize the hydrogeology and water quality of known groundwater chemical contamination, horizontally and vertically, and in relation to the potential source areas. These water samples were analyzed for chemical and radiological constituents, as appropriate. Two interim groundwater remediation systems operated in Area IV during 1997, one at the Former Sodium Disposal Facility (FSDF) and the other at the Radioactive Material Handling Facility (RMHF).

Surface discharges of water, after use in rocket-engine testing and other industrial purposes, were analyzed at least monthly for 84 analytes and quarterly for 169 analytes per discharge location. Three existing trichloroethylene occurrences in the groundwater in the northwest part of Area IV were monitored in 1997. No new offsite plume of degraded groundwater was detected from these wells.

There are 7 monitoring wells in the vicinity of the De Soto facility, 1 up gradient and 6 down gradient from the facility. Monitoring of these wells since 1989 indicates that off site sources contribute to the volatile organic compounds found in the groundwater beneath the facility.

During 1997, 22 Area IV and 1 De Soto regulatory agency inspections, audits, and visits were conducted. One Notice of Violation (NOV) was issued during 1997 as a result of these inspections. This NOV was generated when Rocketdyne reported the inadvertent removal of a rolloff bin of demolition debris prior to notification to the state. These inspections were carried out by the California Department of Toxic Substances Control (DTSC) the California Department of Health Services Radiologic Health Branch (DHS-RHB), the Los Angeles Regional Water Quality Control Board (LARWQCB), the US Department of Energy (DOE), the US Environmental Protection Agency (EPA) an the Los Angeles City Fire Department (LAFD).

The results of an epidemiological study of current and former radiation workers at SSFL conducted by the University of California at Los Angeles (UCLA) were released in 1997. The study found when comparing the general U.S. population and Rocketdyne/AI workers monitored for external or internal radiation, Rocketdyne/AI workers experienced lower mortality rates from all causes, all cancers, and heart disease. Comparison of monitored Rocketdyne/AI workers with National Institute of Occupational Safety and Health (NIOSH)-cohort members of comparable pay type, showed lower mortality rates for all causes and heart disease, but similar rates for total cancers for the Rocketdyne/AI workers. 
The UCLA study alleged to have found a higher mortality rate from leukemias and increased risk of dying from cancers of the "upper-aerodigestive tract". Peer reviewers identified numerous methodological problems with the study, which call these findings into question.

In summary, this Annual Site Environmental Report provides information showing that there are no indications of any potential impacts on the health and safety of the public, near or distant, due to the operations conducted at the Santa Susana Field Laboratory and the De Soto site. All measures and calculations of offsite conditions demonstrate compliance with applicable regulations. These measurements confirm that the control of releases of hazardous substances from Rocketdyne operations is extremely effective.

At the end of 1996 (December 6), the merger with The Boeing Company with the aerospace and defense operations of Rockwell International, including the Rocketdyne Division and the DOE operations at the Santa Susana Field Laboratory, was completed. This report uses historically correct terms for the organizations involved in the environmental monitoring and protection during 1997.

3 


\section{INTRODUCTION}

This annual report discusses environmental monitoring at two manufacturing and test sites operated in the Los Angeles area by Rocketdyne Propulsion \& Power of Boeing North American, Inc. These are identified as Area IV of the SSFL and the De Soto site. These sites have been have been used for research and development (R\&D), engineering, and testing in a broad range of technical fields primarily in energy research and nuclear reactor technology. The De Soto site had research and development laboratories involved with nuclear research. This work was terminated in 1995 and only D\&D activities will have potential for impact on the environment. Area IV at SSFL, because of its large size (290 acres) and the nature of past operations, warrants comprehensive monitoring to ensure protection of the environment. Monitoring was also carried out at the De Soto facility.

The SSFL consists of four administrative areas used for research, development, and test operations as well as a buffer zone. The arrangement of these areas is shown in Figure 2-1. Approximately 90 acres of the 290 acres of Area IV is under the jurisdiction of the Department of Energy.

The primary purpose of this report is to present information on environmental and effluent monitoring of DOE-sponsored activities to the regulatory agencies responsible for oversight. Information presented here concentrates on Area IV at SSFL, which is the only area at SSFL where DOE operations were performed. In addition, this report attempts to communicate to our workers, neighbors, and customers, factual information regarding the condition of our environment. To assist us in this effort, a reader response survey form has been included in the front of this report. We would appreciate your comments.

Since 1956, Area IV has been used for work with nuclear materials, including fabricating nuclear reactor fuels, testing nuclear reactors, and dissembling used fuel elements. This work ended in 1988 and subsequent efforts have been directed toward decommissioning and decontamination of the former nuclear facilities.

Work in nuclear energy R\&D in what has become Rocketdyne Propulsion \& Power of Boeing North American began under North American Aviation, Inc. in 1946. During the evolution of these operations, small test and demonstration reactors and critical assemblies were built and operated, reactor fuel elements were fabricated, and used fuel elements were disassembled and declad. These projects have been completed and terminated in the course of the past 30 years. Most of this work was performed at Area IV of the SSFL and is described in detail in the Rocketdyne document "Nuclear 


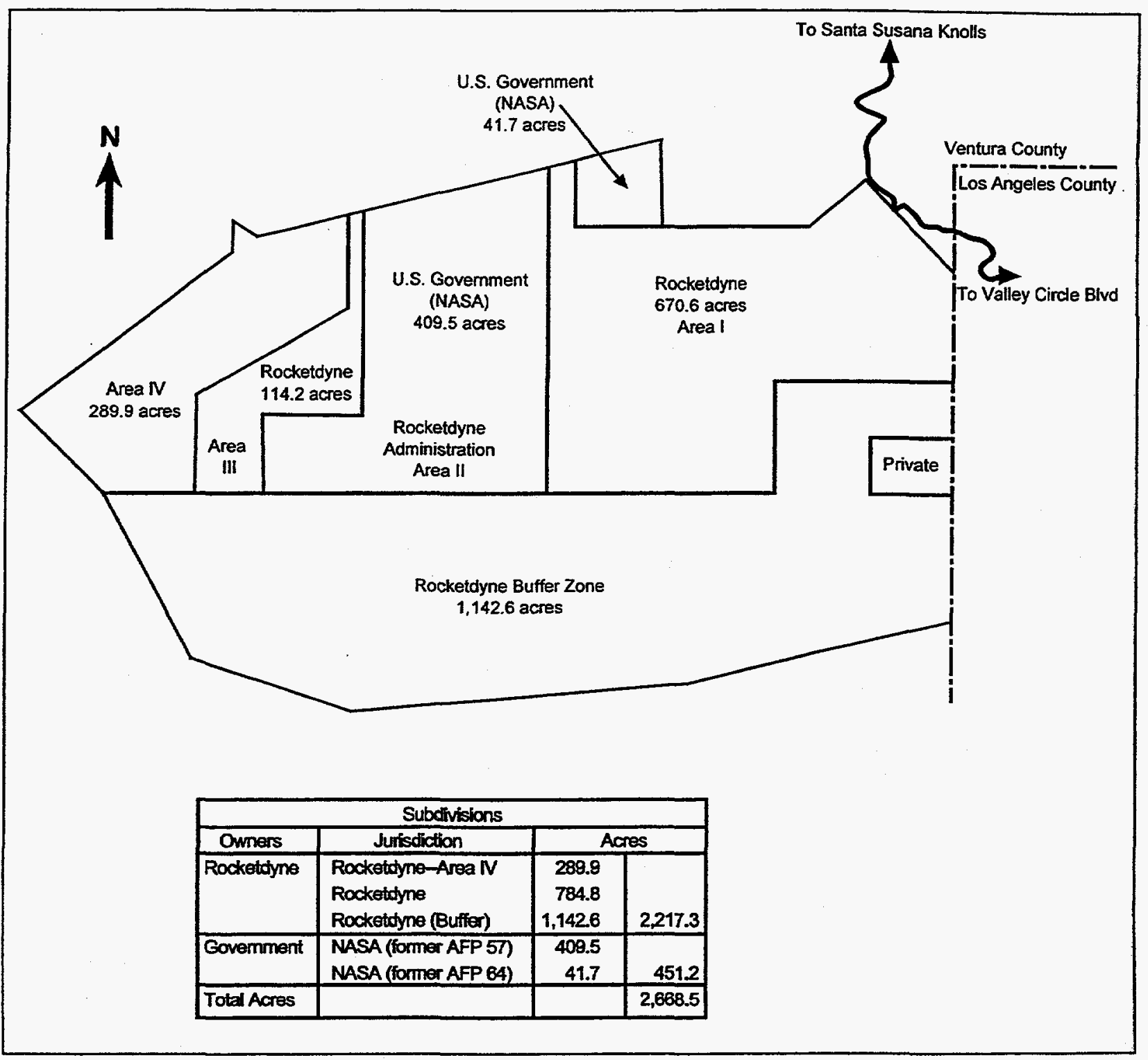

Figure 2-1. Santa Susana Field Laboratory Site Arrangement 
Operations at Rockwell's Santa Susana Field Laboratory - A Factual Perspective" (Ref. 1). No work with nuclear materials has been conducted at SSFL since 1988, and the only work related to these operations since that time and during 1997 was the ongoing cleanup and decontamination of the remaining inactive nuclear facilities, and the offsite disposal of radioactive waste.

The nuclear operations and the ensuing cleanups have been conducted under State and Federal licenses and under contract to DOE and its predecessors. In April 1990, the Nuclear Regulatory Commission (NRC) Special Nuclear Materials license was amended to permit only decommissioning operations. Following transfer of ownership of the Hot Laboratory (Hot Lab) from Rockwell International to the DOE, and reflecting the close involvement of DOE in the decommissioning operations, the NRC terminated the Special Nuclear Materials license in September 1996 and relinquished responsibility and jurisdiction over the Hot Lab to the DOE (See Section 2.1.1.1).The location of the SSFL site in relation to nearby communities is shown in Figures 2-2 and 2-3. Undeveloped land surrounds most of the SSFL site. There are occasionally cattle grazing on land near the southern portion of the site, and the Santa Monica Conservancy's Sage Ranch Park is at the northeastern boundary of SSFL. No significant agricultural land use exists within $30 \mathrm{~km}$ (19 miles) of the SSFL site. While the land immediately surrounding SSFL is undeveloped, at greater distances there are suburban residential areas. For example, 2.7 $\mathrm{km}$ (1.7 miles) northwest of Area IV is the closest residential portion of Simi Valley. The community of Santa Susana Knolls lies $4.8 \mathrm{~km}$ (3.0 miles) to the northeast, and a small truck farm exists approximately $7 \mathrm{~km}$ ( 4.4 miles) to the northeast. The Bell Canyon area begins approximately $2.3 \mathrm{~km}$ (1.4 miles) to the southeast, and the Brandeis-Bardin Institute is adjacent to the north. A sand and gravel quarry was operated approximately $2.4 \mathrm{~km}$ (1.5 miles) to the west but is now abandoned.

The Los Angeles basin is a semiarid region whose climate is controlled primarily by the semi-permanent Pacific high-pressure cell that extends from Hawaii to the Southern California coast. The seasonal changes in the position of this cell greatly influence the weather conditions in this area. During the summer months, the highpressure cell is displaced to the north. This results in mostly clear skies with little precipitation. During the winter, the cell moves sufficiently southward to allow some Pacific lows with their associated frontal systems to move into the area. This produces light to moderate precipitation with northerly and northwesterly winds.

During the summer, a shallow inversion layer generally exists in the Los Angeles area. The base and top of this inversion layer usually lie below the elevation of the SSFL site. Thus, any atmospheric release from the SSFL site during the summer would likely result in considerable atmospheric dispersion above the inversion layer prior to any diffusion through the inversion layer into the Simi or San Fernando Valleys. In the winter season, surface airflow is dominated by frontal activity moving easterly through the area. Storms passing through the area during the winter are generally accompanied by 
rainfall. Airborne mixing varies depending on the location of the weather front relative to the site. Generally, a light to moderate southwesterly wind precedes these storms, introducing a strong onshore flow of marine air and producing slightly unstable air. Wind speeds increase as the frontal systems approach, enhancing mixing and dispersion. Locally, average wind speeds range from 0 to $4.4 \mathrm{~m} / \mathrm{s}$ ( 0 to $9.8 \mathrm{mph}$ ), mostly from the north and northwest.

Except for the Pacific Ocean approximately $20 \mathrm{~km}$ (12 miles) south, no recreational body of water of noteworthy size is located in the surrounding area. Four major reservoirs providing domestic water to the greater Los Angeles area are located within 50 $\mathrm{km}$ (30 miles) of SSFL. However, the closest reservoir to SSFL (Bard Reservoir, near the west end of Simi Valley) is more than $10 \mathrm{~km}$ ( 6 miles) from Area IV. The nearest groundwater well that is used for a municipal water supply is more than $16 \mathrm{~km}$ (10 miles) from Area IV, north of Moorpark.

The SSFL site occupies 2,668 acres located in the Simi Hills of Ventura County, approximately $48 \mathrm{~km}$ (30 miles) northwest of downtown Los Angeles. The SSFL is situated on rugged terrain with elevations at the site varying from 500 to $700 \mathrm{~m}(1,650$ to $2,250 \mathrm{ft}$ ) above sea level (ALS). Rocketdyne and DOE owned facilities (Figures 2-4 and 2-5) share the Area IV portion of this site.

Within Area IV of the SSFL site is a 90-acre area where DOE contract activities are conducted. All the DOE work is now performed by the ETEC, operated by Rocketdyne. The major operational nuclear installation within the DOE area is the Radioactive Materials Handling Facility. This facility has been used for storage of sealed irradiated nuclear reactor fuel materials and for packaging radioactive wastes resulting from nuclear facility decommissioning operations. No nuclear fuel has been present at the RMHF since May of 1989 when the last packages of disassembled Fermi reactor fuel were shipped to another DOE site. Radioactively contaminated water produced in the decontamination operations is evaporated and the sludge is dried and disposed as packaged dry waste together with other dry wastes at a DOE disposal site.

The SSFL site also contains facilities in which operations with nuclear materials licensed by the NRC and radioactive materials licensed by the State of California were conducted, principally at the Hot Lab. The NRC Special Nuclear Materials license was terminated on September 9, 1996, and jurisdiction for the Hot Lab was transferred to the DOE. During 1997, activities were directed toward the final D\&D of the Hot Lab. This work was largely completed with the removal of the basement structure and the backfilling of the excavation. 


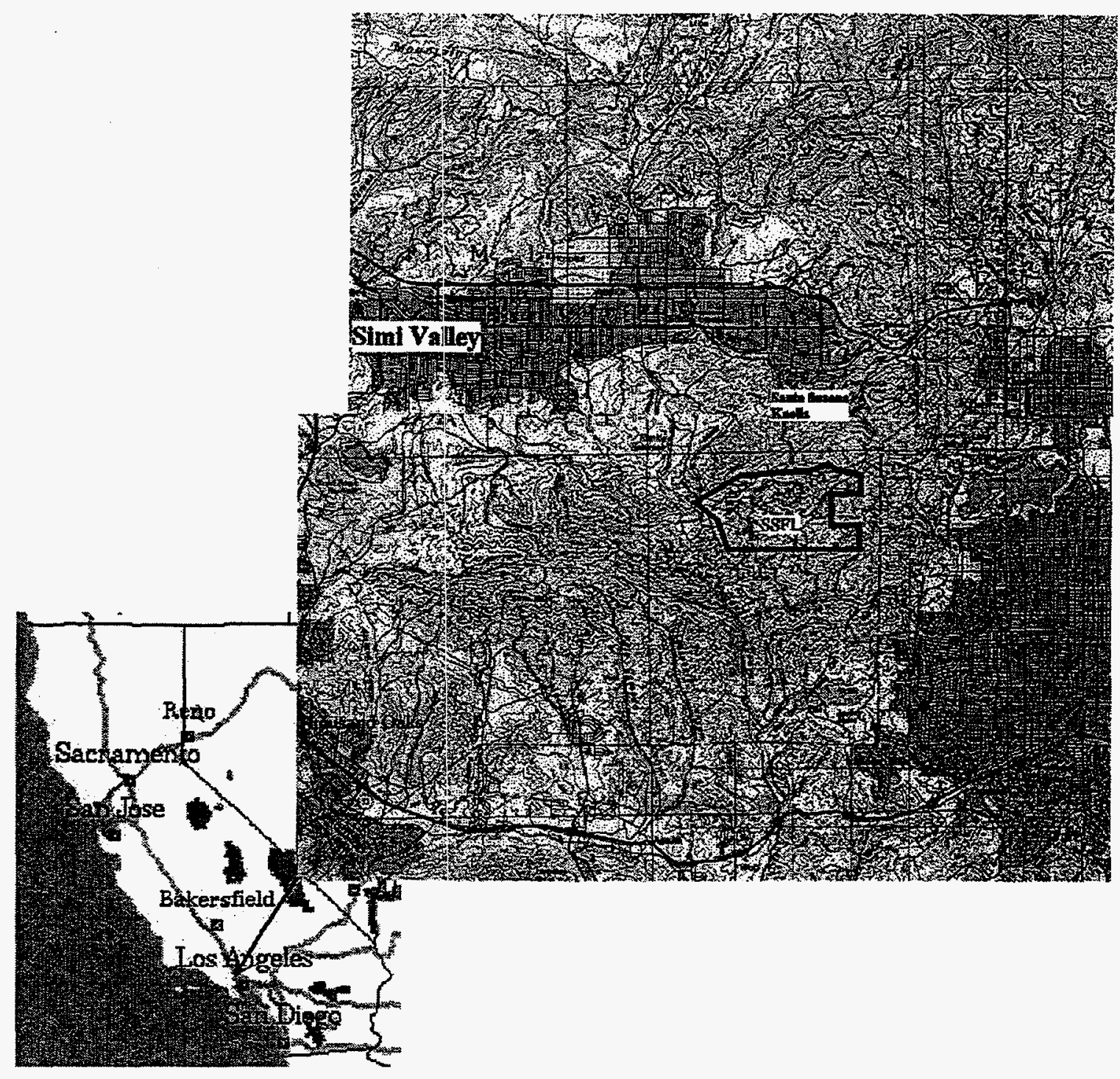

Figure 2-2. Map Showing Location of SSFL 


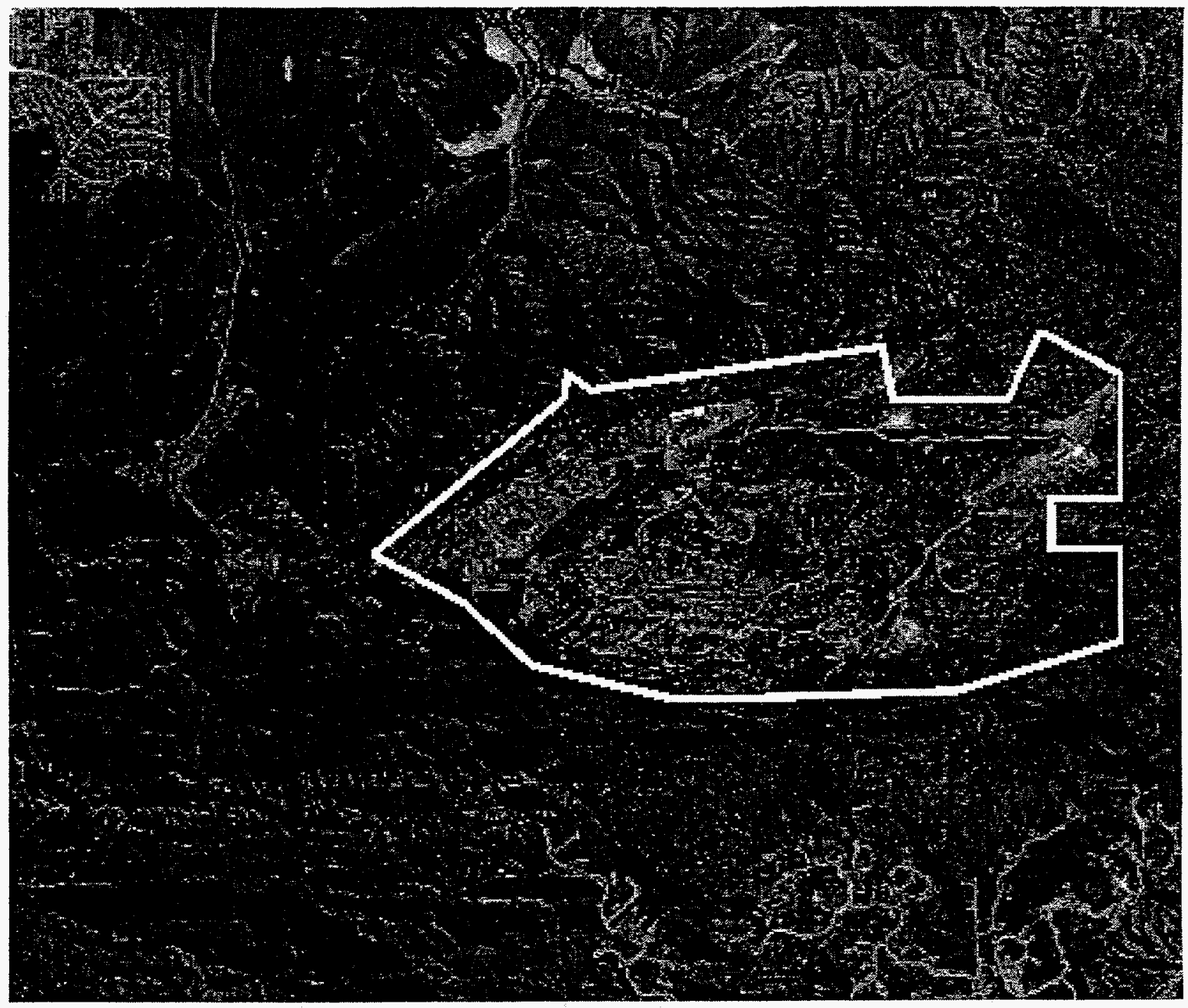

Figure 2-3. Area Surrounding SSFL 


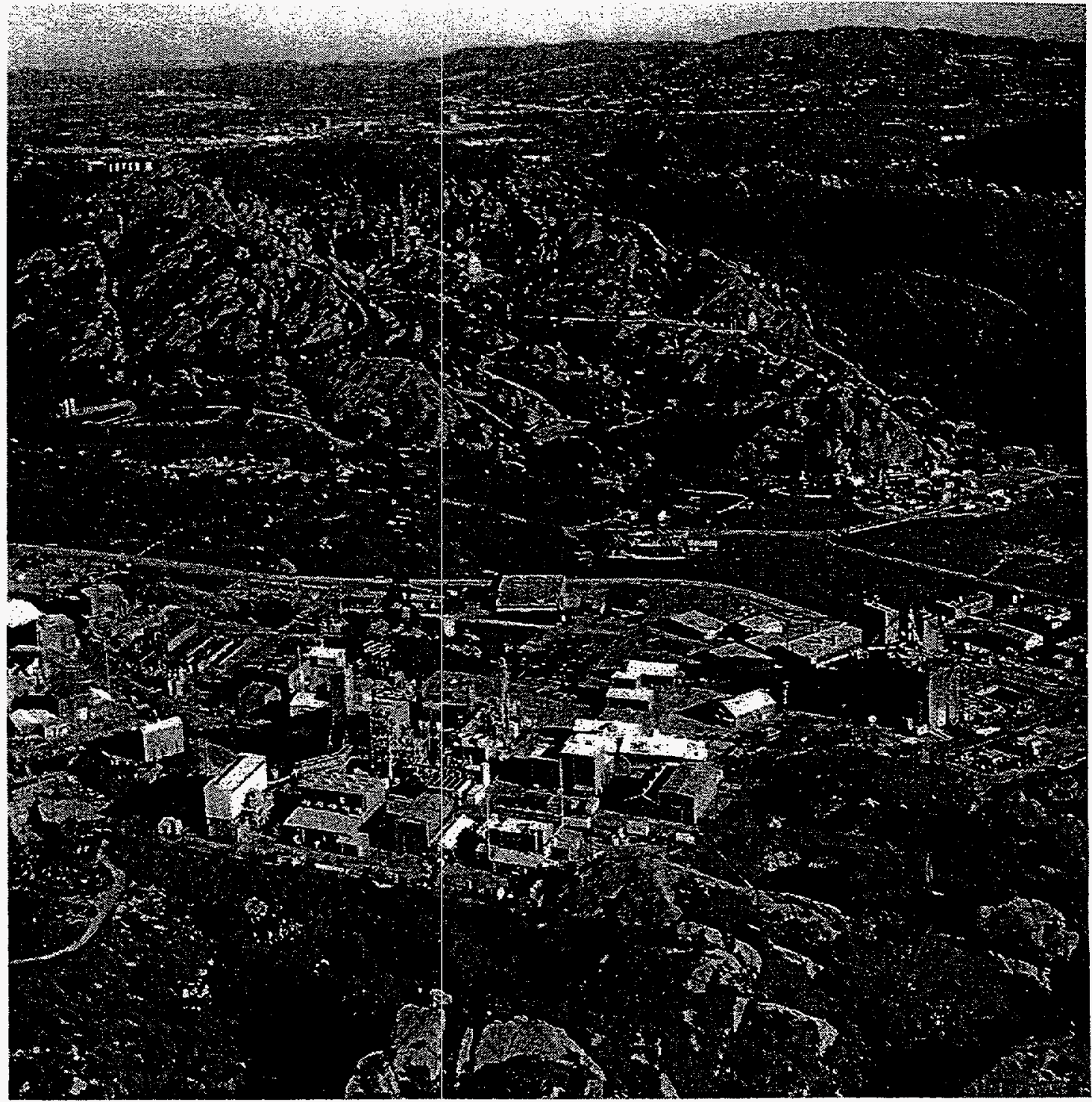

Figure 2-4. Rocketdyne Propulsion \& Power - Santa Susana Field Laboratory Sïte, Area IV 


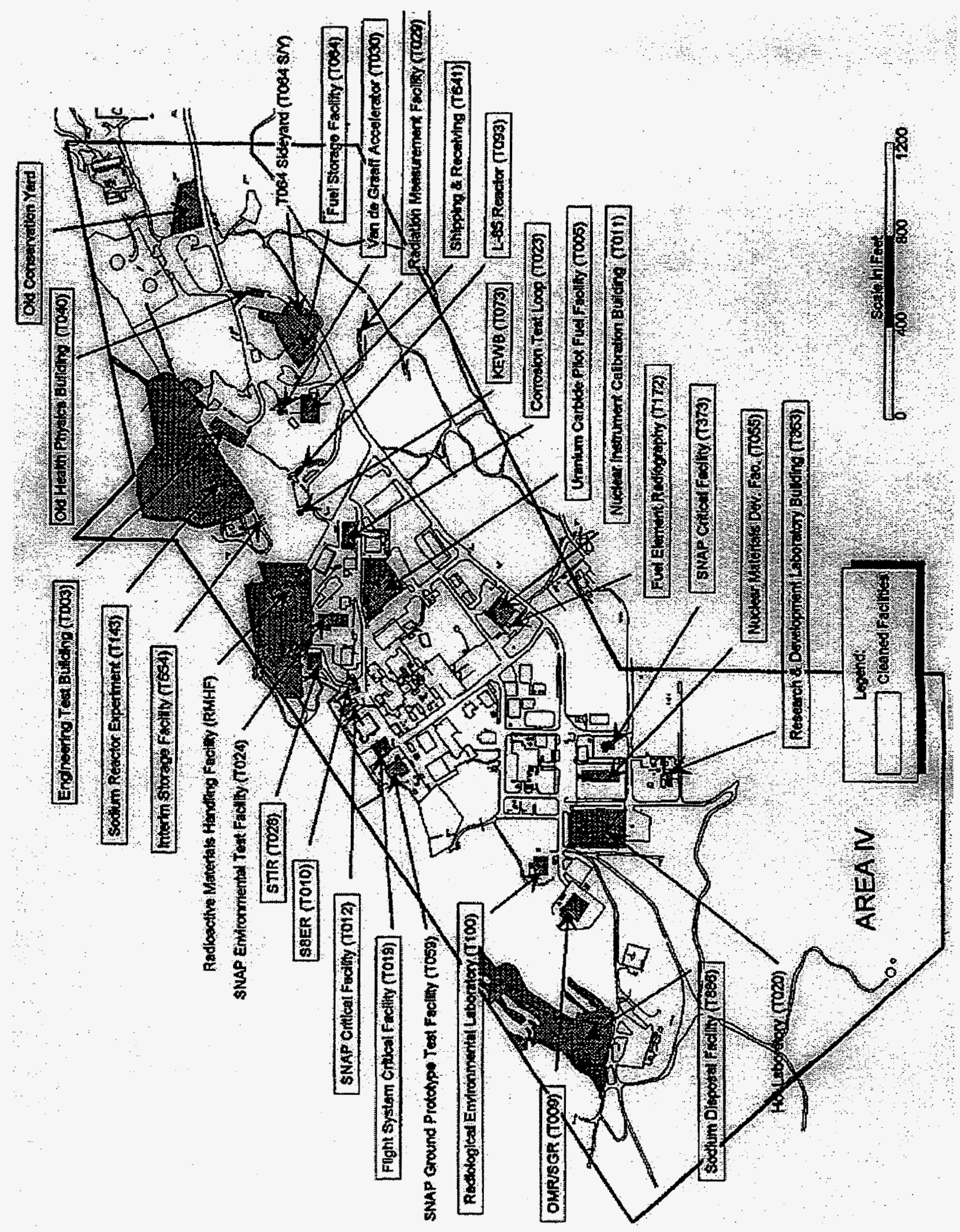

Figure 2-5. Map of Santa Susana Field Laboratory Area IV Facilities 
Up until 1995, research using radioactive materials for DOE and licensed by the State of California was conducted at the De Soto site (Figure 2-6) in the Building 104 Applied Nuclear Technology Laboratories. Irradiation operations in the Gamma Irradiation Facility were terminated in 1994 and the radiation sources were shipped offsite. Operations at the Helium Analysis Laboratory were terminated in May 1995, and the equipment was relocated to Battelle - Pacific Northwest National Laboratories (PNNL) in Richland, Washington. This transfer terminated all work (other than D\&D) with radioactive materials at the De Soto site.

Surrounding the De Soto complex is light manufacturing, other commercial establishments, apartment buildings, and single-family homes. The De Soto facility is at an altitude of $267 \mathrm{~m}$ ( $875 \mathrm{ft}$ ) ASL on generally flat terrain. 


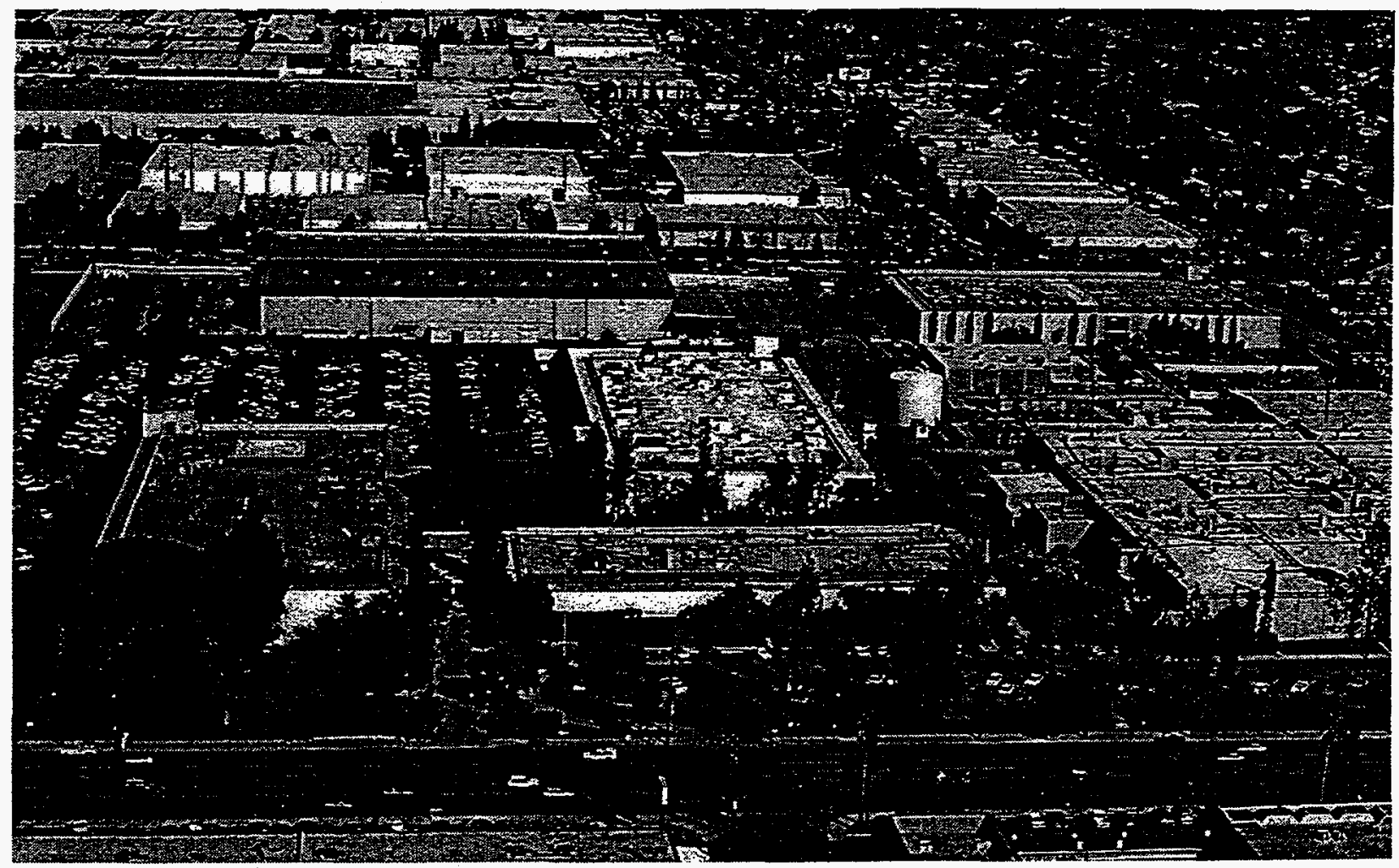

Figure 2-6. Rocketdyne Propulsion \& Power - De Soto Site 
FACILITY DESCRIPTIONS

2.1.1 Santa Susana Field Laboratory Site

2.1.1.1

DOE Contract Activities

\section{RMHF}

Operations at Buildings 4021 and 4022 (RMHF) that may generate radioactive effluents consist of the processing, packaging, and temporary storage of liquid and dry radioactive waste material for disposal. Only filtered atmospheric effluents, filtered for particulates, are released from the buildings to uncontrolled areas. Tritium, a non-particulate radioisotope is also released. No radioactive liquids are released from the facility. Radioactive materials from nuclear fuel and decontamination operations contain uranium and plutonium plus Cs137 and $\mathrm{Sr}-90$ as mixed fission products, and $\mathrm{Co}-60$ and Eu-152 activation products.

Groundwater was pumped throughout 1997 as part of an interim groundwater remediation program. Approximately 665,411 gallons of degraded groundwater were pumped and treated at the RMHF Area Interim Extraction and Treatment System (ETS) in 1997.

\section{Building 4059}

Operations at Building 4059 that may generate radioactive effluents consist of removal of activated steel and concrete as part of the D\&D of this former Systems for Nuclear Auxiliary Power (SNAP) reactor ground test facility. The Atomics International Division designed, built, and tested at SSFL several SNAP reactors, as part of the "Systems for Nuclear Auxiliary Power." All reactors in this program were given even numbers, while those units that used the decay of radioactive material to provide heat were given odd numbers. (One reactor, SNAP-10A, was launched into Earth orbit in 1965, operated successfully, was automatically shutdown, and remains in a distant orbit.) Only filtered atmospheric effluents may be released from the building to uncontrolled areas during operations. No radioactive liquid waste is released from the facility. Activation products consist primarily of $\mathrm{Fe}-55$, Eu152 , and $\mathrm{Co}-60$, and minimal amounts of H-3. Since no radiological work was performed in the building in 1997, no effluent monitoring was performed.

In 1997, dismantling of the Large Leak Test Rig (LLTR), equipment that had been used for sodium system safety tests, continued, starting in the High Bay and working down to the Vault area. (In 1996 approximately 25,600 pounds of sodium was off loaded from the facility drain tank to a sodium supplier.) In 1997 the drain tank was cleaned using a Water Vapor Nitrogen (WVN) process which reacts sodium with water vapor in an inert nitrogen atmosphere to produce sodium hydroxide. Approximately 1,542 pounds of sodium were removed during cleaning. The Reaction Products Tank (RPT), which received reaction products from sodium-water interaction tests, was cleaned in place using the WVN process. Approximately 34,300 pounds of sodium were removed by this process in 1997 . The sodium hydroxide that was produced as a result of this cleaning process was recycled. 


\section{6, Former Sodium Disposal Facility}

All radioactive contamination was removed from the Former Sodium Disposal Facility, in 1994. Final and confirmatory surveys have shown that no radioactivity exceeding allowable limits remains in that area. The DHS/RHB performed a final round of sampling in the Upper Basin and western area in 1997.

An interim ETS was operated at the FSDF from April through December 1997. Approximately 28,000 gallons of degraded groundwater were treated.

\section{Buildings 4023 and 4064}

D\&D activities for Building 4023 was limited to the removal of asbestos containing materials. Building 4023 was released for unrestricted use and current plans call for the building to be demolished (Ref. 2). Building 4064 was demolished in 1997 and all structure was removed. Contaminated soil in the side yard area of 4064 was also removed. The side yard area is awaiting a final confirmation survey prior to release, scheduled for 1998 (Ref. 3).

\section{Buildings 4012 and 4363}

D\&D activities for Buildings 4012 and 4363 were completed in 1995. Final Rocketdyne radiological surveys (Ref. 4, 5, and 6), and confirmatory radiological surveys by the Oak Ridge Institute for Science and Technology (ORISE) (Refs. 7 and 8), were performed for both buildings in 1996. The results of these surveys showed that the facilities met the radiological requirements for release without radiological restrictions. Building 4012 was released for unrestricted use in 1997. DHS/RHB released Building 4363 for unrestricted use.

\section{Building 4030}

Building T030 was released for unrestricted use by DOE in 1997. Release by the DHS/RHB is pending. The building is scheduled for demolition.

\section{Building 4020 (Hot Lab)}

Operations at Building 4020 (Hot Lab) that may have generated radioactive effluents in the past consisted of hot cell examination and decladding of irradiated nuclear fuels and examination of reactor components. Prior radioactive material handled in unencapsulated form in this facility included the following radionuclides that are now present only in minor amounts as facility contamination: $\mathrm{U}, \mathrm{Pu}$, as constituents in the various fuel materials; Cs-137 and Sr-90 as mixed fission products; and Co-60.

The NRC license for the former Hot Lab was terminated on September 27, 1996, and the facility was transferred to DOE jurisdiction. Decommissioning work continued under DOE sponsorship. D\&D activities were largely completed in 1997 with the removal of the basement and backfilling of the excavation. Large concrete blocks resulting from the basement demolition are surveyed by Rocketdyne and the state DHS/RHB to verify no contamination exists prior to off site disposal. Some decontamination of concrete blocks is performed at building 4024 . Since 4020 was shut down in 1988 , only decontamination of the 
facility was performed in 1997. Only filtered atmospheric effluents and resuspended soils were released from the building during $D \& D$ activities. No radioactive liquids are released from the facility. The facility is now completely demolished. The final radiological survey of the area will be performed prior to release.

\subsubsection{ETEC Operations}

The primary purpose of operations at ETEC is the environmental restoration of SSFL areas and facilities that have been impacted by DOE operations. A longer-term objective is to provide a transition of the DOE facilities to a commercially available test facility.

\section{Building 4026}

Building 4026 housed the Sodium Components Test Loop (SCTL). This facility was used in the testing of small components such as valves and pumps in liquid sodium. In 1996 the sodium in the facility drain tanks (approximately 103,930 pounds) was offloaded to a sodium supplier. In 1997, the two below grade drain tanks were removed and cleaned using the WVN process. Approximately 14,300 pounds of sodium was converted to sodium hydroxide during the cleaning process. The sodium hydroxide was recycled and the tanks were cut up and sold as scrap.

Also in 1997 the extensive sodium piping system in the SCTL was removed and the pipe cleaned using the WVN process. The sodium hydroxide generated was recycled and the clean pipe was sold as scrap.

\section{Building 4032}

Building 4032 housed the Liquid Metal Development Laboratory \#1 (LMDL 1) which carried out applied research in support of liquid metal cooled reactors. In 1996, approximately 15,930 pounds of sodium was off loaded to a sodium supplier from the single below grade drain tank. During 1997, the drain tank was removed and cleaned using the WVN process. Approximately 1,542 pounds of sodium was converted to sodium hydroxide during the cleaning process. The sodium hydroxide was recycled and the tank cut up and sold as scrap.

\section{$17^{\text {th }}$ Street Drainage}

In 1997, expanded sampling in Area IV identified an area of low level soil contamination (Cesium-137) designated the $17^{\text {th }}$ Street Drainage Area. Throughout 1997 this area was covered with dense brush and was not considered to be a release point for radioactivity.

\subsubsection{De Soto Site}

\section{Building 104 - California State-Licensed Activities}

Operations at Building 104 that could have generated radioactive effluents consisted of research studies in applied physics and physical chemistry using activated materials. Analysis of low-level activated test samples in the mass spectrometer 
laboratory was terminated in May 1995. The laboratory was relocated to a DOE facility at Battelle - Pacific Northwest National Laboratories in early 1996. In late 1997 removal of equipment remaining in the Helium Analysis Laboratory was completed to allow D\&D activities to begin in 1998. Airflow through the dormant laboratory areas was maintained. This ventilation exhaust is passed through High Efficiency Particulate Air (HEPA) filters before being released from the building to uncontrolled areas. No liquid effluents are released. 


\section{COMPLIANCE SUMMARY}

This section summarizes Rocketdyne's compliance with federal, state, and local environmental regulations. Two main categories are presented; Section 3.1 discusses compliance status, and Section 3.2 discusses current issues and actions.

\subsection{COMPLIANCE STATUS}

\subsubsection{Radiological}

The results of radiological environmental monitoring indicate that there are no significant releases of radioactive material from the SSFL or De Soto sites. Atmospheric transport of radioactive materials and direct exposure during ETEC's environmental remediation and waste management operations are the only credible pathways to the general public. A small area of soil containing low levels of tritium occurs in an undeveloped area north of Area IV that is very isolated, where no exposure is likely. This soil is found near where a reactor test building (Building 4010) had been excavated in 1978. Operation of this reactor in the 1960s produced small amounts of tritium in the ground. The tritium content is below the drinking water standard. (Analytical results for tritium in groundwater are presented in Section 5.4.2.)

\section{Airborne Releases}

Small amounts of radioactive materials may be released in ventilation exhaust from facilities at SSFL and De Soto, along with naturally occurring airborne radioactivity. These releases are minimized by using HEPA filters, and are continuously monitored by sampling the exhaust effluent. Radionuclide-specific analyses determine the radioactive composition of these effluents, and maximum offsite doses at the nearest residence from this source are estimated by using the EPA computer program CAP88-PC (Ref. 9).

Considering airborne releases from the RMHF exhaust stack and the Building 4024 exhaust unit, and including three diffuse area sources, the maximum individual annual exposure was estimated at $1.7 \times 10^{-4} \mathrm{mrem} / \mathrm{yr}$ for DOE operations at SSFL. Similarly, licensed operations at De Soto site were estimated to have resulted in $4.9 \times 10^{-6} \mathrm{mrem} / \mathrm{yr}$ for airborne releases. All effective dose equivalents for the maximally exposed individual are far below the EPA National Emissions Standards for Hazardous Air Pollutants (NESHAPs) limit of $10 \mathrm{mrem} / \mathrm{yr}$, and below the action level of $1 \%$ of the limit ( $0.1 \mathrm{mrem} / \mathrm{yr})$ as specified in 40 CFR 61 , Subpart H (DOE facilities) and Subpart I (licensed facilities). Additional calculations were done for the licensed De Soto facility using the EPA computer program COMPLY (Ref. 10) to demonstrate compliance under Subpart I of the NESHAPs regulations. These calculations showed compliance at the simplest level in COMPLY.

\section{Water Releases}

All liquid radioactive wastes are processed by either solidification or evaporation prior to disposal at DOE disposal sites. Liquid radioactive wastes are not released into the environment 
and do not constitute an exposure pathway. Groundwater and surface water are sampled and analyzed to assure detection of any non-natural radioactivity.

At SSFL, 243 groundwater monitoring wells included in the monitoring system are sampled and analyzed periodically and no indication of non-natural radioactivity has been found, with the exception of low levels of tritium in Well RD-34A (approximately $4,870 \mathrm{pCi} / \mathrm{L}$ in 1997 , see Section 5.5.2), considerably below the Federal and State standards for drinking water of $20,000 \mathrm{pCi} / \mathrm{L}$. Tritium was detected just above the analytical detection limit $(200 \mathrm{pCi} / \mathrm{L})$ in six other wells. Wells with detectable tritium are quite widely separated, near Building 4059, in the canyon north of the RMHF, and at the Former Sodium Disposal Facility (4886). Occasional results for gross alpha radioactivity that exceeded the maximum contamination level (MCL) are attributed to naturally occurring uranium (Ref. 11).

Extracted groundwater from the French drain at 4059 is periodically sampled and analyzed by gamma spectroscopy. These water samples are tested by gamma spectroscopy for any transfer of gamma-emitting activation products from the underground reactor test vault containment into the surrounding soil. Potential radionuclides include Co-60 and Eu-152, both of which are easily detected, and none have been found to date. This water was sampled 3 times in 1997, and no non-natural radioactivity was detected.

Surface water from two National Pollutant Discharge Elimination System (NPDES) discharge points and five storm water runoff catch basins are also monitored. The Rocketdyne NPDES permit allows the discharge of reclaimed wastewater and storm water runoff from water retention ponds into Bell Creek, a tributary to the Los Angeles River, in addition to the discharge of storm water runoff from the northwest slope (Area IV) locations. Excess reclaimed water, including treated sanitary sewage and runoff from Area IV, is now discharged on a continuous basis through the R-2A outfall location (Outfall 002). Discharge along the northwest slope of Area IV (Outfalls 003 through 007) generally occurs only during and after periods of heavy rainfall. Two of these drainage channels (003 and 004) flow directly from DOE territory. The permit applies the numerical limits for radioactivity in drinking water supplies to drainage through these outfalls. The permit requires radiological measurements of gross alpha, gross beta, tritium, strontium-90, and total combined radium-226 and radium-228. No NPDES samples exceeded drinking water supplier limits for radioactivity, as imposed by the permit. No exceedances for conventional parameters were observed for any of the outfalls from Area IV in 1997. In 1997, there were 45 sampling events.

\section{Site Boundary Exposures}

The external radiation exposure estimates at the maximum exposed boundary location and at the nearest residence are based on results from site ambient radiation dosimeters and facility workplace radiation dosimeters. Adjacent to the RMHF, the external exposure from direct radiation at the maximum exposed boundary location was estimated from the 1997 measurements to correspond to an average annual dose of approximately $48 \mathrm{mrem}$ above natural background. (This is equivalent to an average exposure rate of $5.5 \mu \mathrm{R} / \mathrm{hr}$.) A value of 0.00017 mrem/yr was calculated for the nearest residence. These values are considerably below the DOE 
long-term limit of $100 \mathrm{mrem} / \mathrm{yr}$. For the Hot Lab, the removal of the radioactive liquid waste holdup tank in 1994 eliminated any source of external exposure, so that radiation exposures there are now virtually indistinguishable from natural background. However, the site was still monitored in 1997, and showed $0.002 \mathrm{mrem} / \mathrm{yr}\left(2.3 \times 10^{-4} \mu \mathrm{R} / \mathrm{hr}\right)$ at the nearest boundary and 1.3 $\mathrm{x} 10^{-7} \mathrm{mrem} / \mathrm{yr}$ at the nearest residence.

At the De Soto facility, the external exposure from direct radiation at the maximum exposed boundary location was $0.08 \mathrm{mrem} / \mathrm{yr}\left(9.4 \times 10^{-3} \mu \mathrm{R} / \mathrm{hr}\right)$ and $0.06 \mathrm{mrem} / \mathrm{yr}$ at the nearest residence.

\subsubsection{Comprehensive Environmental Response, Compensation, and Liability Act}

The Comprehensive Environmental Response, Compensation, and Liability Act (CERCLA) regulates reporting and emergency response for hazardous substances released into the environment and for the cleanup of abandoned hazardous waste sites or other historical hazardous waste releases. Under the historical release authority of CERCLA, a Preliminary Assessment/Site Investigation (PA/SI) review of SSFL Area IV was conducted by the EPA Site Evaluation Section. A report of findings, dated 11 August 1989, was transmitted to ETEC in April 1990. The SSFL ranked below the criteria for being included on the National Priority Listing. There was no further activity on this in 1997.

However, discussions with DOE have resulted in agreement to incorporate CERCLA-type protocols per DOE policy into the cleanup activities at SSFL, although cleanup activities will be conducted under Resource Conservation and Recovery Act (RCRA) corrective-action rules.

The Superfund Amendments and Reauthorization Act (SARA) extended the regulatory provisions of CERCLA. SARA Title III requires extensive hazardous material reporting, community right-to-know, and emergency response planning provisions. ETEC has met the SARA reporting requirements. The SSFL Hazardous Materials Release Response Business Plan and Inventory was issued to Ventura County Environmental Health Division (VCEHD) on October 27, 1997, addressing the following SARA Title III provisions:

1. Planning, Emergency Response

2. Reporting, Leaks and Spills

3. Reporting, Chemical Inventories

4. HAZMAT Training Program

5. Facility Maps and Diagrams.

SARA Title III also addresses reporting toxic chemical (EPA Form R) usage. Rocketdyne annually submits an EPA Form $R$ report to the Environmental Protection Agency for toxic chemicals handled at ETEC facilities exceeding the reporting threshold quantity of 10,000 lb. The Form R (Toxic Release Inventory) submission was sent to federal agencies by the July 1 , 1998 deadline. For 1997, only ammonia met the threshold quantity for reporting and was duly reported by ETEC (See Table 3-1). The ammonia remaining at ETEC was removed in 1997. 
Table 3-1. Summary of ETEC Compliance with EPCRA in 1997

\begin{tabular}{|l|c|l|l|}
\hline \multicolumn{1}{|c|}{ Requirement } & Done & Not Done & Not Required \\
\hline EPCRA 302-303: Planning Notification & yes & & \\
\hline EPCRA 304: EHS Release Notification & yes & & \\
\hline EPCRA 311-312: MSDS/Chemical Inventory & yes, 312 & & \\
\hline EPCRA 313: TRI Reporting & yes & & \\
\hline
\end{tabular}

\subsubsection{Resource Conservation and Recovery Act}

The Resource Conservation and Recovery Act gives the EPA broad authority to regulate the handling, treatment, storage, and disposal of hazardous wastes. DOE owns and co-operates two RCRA-permitted Treatment, Storage, and Disposal Facilities with ETEC. Permit numbers are listed in Section 3.2.5.

The Radioactive Materials Handling Facility operates as an Interim Status Facility. This facility is used primarily for the handling and packaging of radioactive waste. The Interim Status is required for the storage of small amounts of mixed waste (waste containing both hazardous and radioactive constituents) resulting from decontamination and decommissioning activities at ETEC. Final disposition of the mixed waste is being addressed under the DOE and DTSC approved Site Treatment Plan, which is authorized by the Federal Facilities Compliance Act. The California DTSC inspects the facility annually to ensure compliance with permit requirements. No NOVs were issued in 1997. The Ventura County Environmental Health Department also inspected the facility on April 24, 1997. No NOVs were issued.

The Hazardous Waste Management Facility (HWMF) includes a storage area (4029) and a treatment facility (4133) for reactive metal waste, such as sodium. The RCRA Part B permit for the facility was renewed by the California Department of Toxic Substances Control in 1993. The HWMF is now in final closure.

RCRA also has governing authority of underground tanks that contain hazardous materials. None of the tanks at SSFL are currently subject to those regulations. Area IV has underground storage tanks, some of which store radioactive water, and some metallic sodium. The sodium tanks are not required to be covered by permits by the Ventura County Environmental Health Division. The radioactive water storage tanks are exempt from permitting by the VCEHD. The California Department of Health Services and the Department of Energy are the lead agencies for tanks containing radioactive material. In 1994 one tank for radioactive water was removed as part of the D\&D of the Hot Lab and stored at the RMHF pending decontamination. This tank continues in use as a storage tank for its contents. The other two tanks are in operation at RMHF. In 1997, three sodium storage tanks (one at Building 4032 and two at Building 4026) were removed, cleaned, and sold as scrap metal. Cleaning of a fourth sodium tank located in Building 4059 was completed in 1997 . This tank will remain in place until demolition of the building. 
Under the Hazardous and Solid Waste Amendments of 1984, RCRA facilities can be brought into the corrective action process when an agency is considering any RCRA permit action for the facility. The SSFL was initially made subject to the corrective action process in 1989 by EPA, Region IX. The EPA has performed the Preliminary Assessment Report and the Visual Site Inspection portions of the RCRA Facility Assessment (RFA) process.

The State of California DTSC has RCRA authorization and has become the lead agency in implementing the corrective action process for the SSFL. ETEC has performed soil sampling at various Solid Waste Management Units (SWMUs) and Areas of Concern (AOCs) that were identified in the RCRA Facility Investigation (RFI) Work Plan.

The current conditions report and a draft of the RCRA Facility Investigation Work Plan for the Area IV SWMUs were submitted to the ITTSC in October 1993. In Area IV, one SWMU, the 4056 Landfill, was proposed for the RFI. In 1994, DTSC issued a letter to Rocketdyne conditionally approving the draft RFI work plan, subject to satisfactory resolution of their comments. A RFI work plan addendum was submitted to DTSC in March 1995, which responded to the DTSC comments. In January 1996, DTSC forwarded draft comments to Rocketdyne on the Area IV SWMUs and AOCs. In November 1996, DTSC approved a revised work plan addendum, which included two additional AOCs in Area IV (Old Conservation Yard and Building 4020). Fieldwork in areas of urirestricted use began in November 1996 and is scheduled for completion in 1998.

\subsubsection{Federal Facilities Compliance Act}

ETEC is managing its modest inventory (approximately $50 \mathrm{~m}^{3}$ ) of mixed wastes in accordance with the Federal Facilities Compliance Act (FFCA)-mandated Site Treatment Plan (STP) approved in October 1995. All known mixed wastes are covered wastes in the STP and any new potential mixed waste discovered is reported to the California Department of Toxic Substances Control through the DOE for inclusion in the STP. Characterization, treatment and disposal plans for each of several different waste streams are defined in the STP with enforceable milestones. These include characterization, reporting, study of treatment options, shipping schedules, and actual removal. ETEC has met all STP milestones to date. Regular updates to reflect changes in inventory or status of mixed wastes and certifications of milestone completion are submitted to DTSC in accordance with the STP.

\subsubsection{National Environmental Policy Act}

The National Environmental Policy Act (NEPA) establishes a national policy to ensure that consideration is given to environmental values and factors in federal planning and decisionmaking. For those projects or actions that are expected to either affect the quality of the human environment or create controversy on environmental grounds, DOE requires that appropriate NEPA actions (Categorical Exclusion [CX], Environmental Assessment [EA], Finding of No Significant Impact [FONSI], or Notice of Intent [NOI], draft Environmental Impact Statement [EIS], final EIS, Record of Decision [ROD]) have been incorporated into project planning 
documents. DOE has implemented NEPA as defined in Federal Register Volume 57, Number 80 , pages 15122 through 15199.

ETEC assesses the environmental impact of each project planned for implementation. Based on the assessments, DOE is requested to issue determinations of compliance to the NEPA. ETEC submitted no request for NEPA determinations in calendar year 1997. There were no draft or final environmental impact statements or reports, site assessments, or remedial action reports produced during 1997. Additionally, there were no actions taken by local authorities and no NOVs relative to CERCLA/Superfund Amendments and Reauthorization Act (SARA) activities for the DOE area.

\subsubsection{Clean Air Act}

The Clean Air Act (CAA) resulted in federal regulations that set air quality standards and required state implementation plans, National Emissions Standards for Hazardous Air Pollutants (NESHAPs), New Source Performance Standards (NSPSs), and monitoring programs in an effort to achieve air quality levels beneficial to the public health and welfare. The SSFL is regulated by the Ventura County Air Pollution Control District (VCAPCD) and must comply with VCAPCD Rules and Regulations. The EPA can enforce VCAPCD rules and also regulates pollutants such as Ozone Depleting Substances (ODS's) under 40 CFR 82. The De Soto facility is under the jurisdiction of the South Coast Air Quality Management District (SCAQMD). VCAPCD and SCAQMD rules and regulations incorporate, by reference, NESHAPs regulations as codified under the CAA. One inspection was performed by VCAPCD, for asbestos in 1997. No violations were identified.

Several steps in asbestos program management have been incorporated into facility renovation and demolition. These generally include assessment or identification of asbestoscontaining materials (ACMs), abatement activities such as worker protection and surveillance, and clearance requirements such as cleanup and disposal. Within Area IV, approximately 100\% of the buildings have been surveyed, and materials in question have been analyzed for asbestos. Where required, asbestos abatement will occur when renovation or demolition projects are identified.

Atmospheric pollutant discharge limitations are imposed by VCAPCD Permit 0271 on natural gas personnel comfort space heaters, boilers in various buildings in Area IV, several natural gas/oil-fired sodium heaters operated by ETEC for component testing, and the Kalina facility. The permit for 1997 was renewed on June 20, 1997.

VCAPCD Rule 74.15, as adopted in March 1989 and revised in December 1991, sets limits for oxides of nitrogen (NOx) and carbon monoxide (CO) emissions on boilers, steam generators, and process heaters. The Sodium Component Test Installation (SCTI) finished installing the new low-NOx burners in 1991 as well as the carbon monoxide continuous emissions monitoring system. An extended variance to the rule was applied for and granted, running through December 31,1992 to allow for source testing and adjusting of the $\mathrm{H}-1$ and $\mathrm{H}-2$ sodium heaters 
and the $\mathrm{H}-101$ boiler to bring them into compliance. Further extensions of the variance were granted to November 30, 1994. ETEC operated under Variance 392-3 until the amended Rule 74.15 was adopted on November 8,1994 . VCAPCD is in the process of revising permit No. 0271. ETEC has been assured by VCAPCD that ETEC is not in violation as long as VCAPCD is processing the permit renewal.

A permit modification application was submitted to VCAPCD on June 3, 1994 to update the permit for language changes, revisions to existing conditions and proposed operations. Included were changes to the Kalina Plant operations that raised the permitted ammonia emissions from 9.3 tons per year and $2.12 \mathrm{lb}$ per hour to 51 and 80 , respectively. The current permit reflects these changes. The Kalina Plant ceased operations in 1996.

Rocketdyne extended the lease for NOx credits for the Steam Accumulator Blowdown Evaluation Rig (SABER) facility boiler in the Bowl Area until January 1998.

Title $\mathrm{V}$ of the Clean Air Act requires issuance of a federal permit for major sources of air pollution. As the present time, ETEC is not a major source of air pollution, therefore no Title $\mathrm{V}$ permit is required. ETEC is operating under VCAPCD Rule 76, Federally Enforceable Limits on Potential to Emit.

Although ETEC has traditionally had little or no ODS's, Rocketdyne has for years maintained a Hazardous Materials Elimination Team to eliminate ODS's at Rocketdyne. This multifunctional team has the responsibility to identify suitable alternatives for various toxic chemicals and has been instrumental in eliminating CFC-113 and 1,1,1-trichloroethane from all of Rocketdyne's Southern California manufacturing operations. ETEC provided DOE with a complete inventory of Class I and Class II ODS's in October 1996.

\subsubsection{Clean Water Act}

The Clean Water Act (CWA) is the primary authority for water pollution control programs, including the National Pollutant Discharge Elimination System permit program. The NPDES program regulates point source discharges of surface water to drainage channels (i.e., to locations other than sewage systems), and the discharge of storm water runoff associated with industrial activities. Basin Plan water quality objectives are applied as effluent standards for offsite discharge of storm and industrial wastewater via the SSFL water reclamation system.

Surface water discharges from SSFL are regulated under the California Water Code (Division 7) as administered by the California Regional Water Quality Control Board (CRWQCB). The existing NPDES Permit (CA0001309) for SSFL, which was revised and became effective June 29, 1998, is expected to remain in force through May 10, 2003. The revised NPDES Permit incorporated federal storm water regulations by requiring development and implementation of a site-wide Storm Water Pollution Prevention Plan (SWPPP). This document is revised as needed and includes by reference many existing pollution prevention plans, policies, and procedures implemented at the SSFL site. Several key elements of the plan, 
including maps, are continually updated. Water from Rocketdyne operations is collected into and discharged from Perimeter Pond and R2A Pond. Sewage from Area IV (including DOE facilities) is treated at the Area III sewage treatment plant, which discharges to the R2A Pond. Most surface runoff from Area IV also drains to R2A Pond. The northwest slope of Area IV drains through five small catch basins.

Another key element is the Rocketdyne procedure "SSFL Storm Water Pollution Prevention Requirements." The Spill Prevention Control and Countermeasure (SPCC) plan serves to identify specific procedures for handling oil and hazardous substances to prevent uncontrolled discharge into or upon the navigable waters of the State of California or the United States. The U.S. EPA requires the preparation of an SPCC plan by those facilities which, because of their location, could reasonably be expected to discharge oil in harmful quantities into or upon navigable waters. A revised Spill Prevention Control and Countermeasure plan was submitted as a part of the revised Spill Prevention and Response Plan to the local Administering Agency on April 12, 1996.

Additionally, an updated hazardous materials inventory was submitted to the VCEHD as an update of the business plan on the same date as the SPCC. The hazardous materials disclosure fee was also submitted.

During periods of rainfall which create adequate runoff for sampling, grab samples of surface water runoff are collected at the discharge points for the Perimeter Pond, R2A Pond, and the five storm water catch basins along the northwest slope of Area IV. When rainfall occurs more than every two weeks or continuously, samples are taken biweekly. During non-rain event discharges from the Perimeter Pond and R2A Pond discharge locations, samples are collected during each discharge event. When discharges occur on a continual basis in excess of a month, samples are collected monthly. The sampling performed at the five northwest slope locations includes quarterly monitoring for a list of analytes referred to as "priority pollutants." There were no exceedances of permit limits at the seven outfalls, with no issuance of violations of the NPDES permit resulting from these analytical results in 1997.

The seven outfalls were in full compliance for 1997. Both the Area I Sewage Treatment Plant (STP I) and the Area III Sewage Treatment Plant (STP III) had minimal occurrences of operating outside permitted parameters. In May 1997, analytical results showed a positive result for coliform at STP I (although still within permit guidelines) and a biological oxygen demand (BOD) removal rate of $78.3 \%$ at STP III. In August 1997, the monthly average removal rate for BOD was $83.5 \%$ at STP III. All three of these incidents called into question the performance of the contract laboratory. Residual chlorine levels were at $3.5 \mathrm{mg} / \mathrm{l}$ at STP I at the time of the alleged coliform detection making it highly suspect that coliform would be present in such a high free chlorine environment. Also that month, the contract laboratory altered its procedure for BOD analyses and subsequently experienced unreliable and uncharacteristic results with multiple samples and clients. Chemical oxygen demand (COD) samples collected from STP III at the same time showed a $96 \%$ removal rate indicating that successful treatment operations existed. As for the reduced removal rate in August 1997 at STP III, one of the four samples that month 
was non-representative of the activities at the STP and therefore indicated an unusually low BOD removal rate of $65 \%$ which lowered the overall monthly average to $83.5 \%$. The three other BOD samples from that month were all above the required $85 \%$ removal rate.

Characterization of the groundwater at the site continues. The most recent phase of DOEfunded groundwater well construction in Area IV approved by DTSC was completed in June 1994. The plan included nine new wells located in Area IV and offsite northwest of Area IV. In 1993, five of these nine wells were installed. In 1994, the four remaining monitoring wells were constructed, 300 to 1,250 feet offsite to the northwest of Area IV. Trichloroethylene (TCE) continued to be detected during 1997 at concentrations ranging from 0.85 to $9.7 \mu \mathrm{g} / \mathrm{L}$ in groundwater approximately 75 to 250 feet northwest of Area IV (in the area of the land acquired under the agreement reached in 1997). In 1997 Boeing entered an agreement to purchase the land on the northern facility boundary and in so doing brought all known facility related affected groundwater back under Boeing property. TCE and other volatile organic compounds (VOCs) were also detected in three onsite areas along the northwestern property boundary.

\subsubsection{Former Sodium Disposal Facility Closure Order}

The 4886 Former Sodium Disposal Facility (Building 4886) was used for removing sodium and sodium-potassium alloys from metal components used in DOE testing programs. The site formerly consisted of a cleaning facility and an Upper Basin and a Lower Basin. A Clean up and Abatement Order was issued on April 30, 1991 by the Los Angeles Regional Water Quality Control Board for Closure of the Lower Basin. The Lower Basin, Upper Basin, and portions of the western area were excavated in 1992-1993. All excavated waste that contained both non-natural radioactivity and hazardous waste (mixed waste) was shipped to a licensed offsite disposal facility in 1994. The low-level radioactive waste was shipped to an offsite disposal facility in 1995.

Chemical analyses of soil have indicated the presence of residual chemical contaminants in the upper basin, western area, and drainage channels. The contaminants of concern were polychlorinated biphenyls (PCBs), dioxins, and mercury. As a result, interim measures have been implemented after consultation with the Department of Toxic Substances Control, including establishment of sediment weirs downslope of the facility. A health-based risk assessment has been performed and is under DTSC review. An interim measure consisting of excavation, backfilling, and re-vegetation will be proposed to DTSC for completion in 1998. Results from radiological analyses have shown no activity above allowable limits and the DHS-RHB released the facility for unrestricted use in 1998.

\subsubsection{Public Participation}

During 1997, Rocketdyne implemented various methods for community outreach, which are detailed in the Santa Susana Field Laboratory Community Involvement Plan. Rocketdyne participated in meetings of the EPA-chaired SSFL Work Group created in 1990 to facilitate exchange of information relating to environmental activities at the SSFL. In support of SSFL

environ.doc 
Work Group meetings, Rocketdyne provided information about current environmental and remediation activities at the site. Throughout 1997, Rocketdyne continued to supply documents for public review to three information repositories: California State University-Northridge Urban Archives Center and the Simi Valley and Platt Branch libraries.

In September 1997, Rocketdyne supported the release of the Rocketdyne Worker Health Study that examined worker exposure to radiation during the period of 1950 to 1993.

Rocketdyne facilitated four meetings, with both current and former employees, and participated in two community meetings. The primary focus of Rocketdyne communications was to ensure that current and former employees and community members received information to help them understand the study findings and what they meant to employee and community health.

Two community meetings, designed as availability sessions, were offered to the public in October 1997. Availability sessions are informal meetings that provide the public with an opportunity to direct questions and express concerns to Rocketdyne staff and technical experts. Similar to an information fair, the availability sessions made use of display boards and exhibits where presenters explained information and used visual displays to enhance understanding of general and environmental activities at the field lab.

As a result of the public's expressed interest in visiting the SSFL to observe the RCRA Facility Investigation soil sampling activities, Rocketdyne implemented a RFI Community Outreach Program in 1997. After participating in a required training session, several groups of community members visited the field lab to observe soil and groundwater sampling activities.

In support of Rocketdyne's Educational Outreach program, the Santa Susana Field Laboratory Council hosts several teacher and student tours each year at the field lab. The tours provide an opportunity for the teachers and students to see the historical site and talk to scientists and engineers involved in field lab programs.

\subsubsection{Agency Inspections/Audits}

A list of inspections and audits by the various agencies overseeing the SSFL and De Soto sites is given in Table 3-2. There was one Notice of Violation as a result of these inspections and audits.

This NOV was issued by the DHS-RHB on Oct. 10, 1997 when Rocketdyne reported that a roll off container of clean demolition debris was removed from the Area IV of SSFL prior to final release by DHS-RHB (DOE Occurrence Report Number SAN-ETEC-GENL-1997-001). The NOV was a violation of license Condition \#13 of Rocketdyne's State Radioactive Materials License 0015-70 (now 0015-19), which requires State resurvey of clean building debris from radiological facilities prior to disposal. Rocketdyne responded to the DHS by letter on Nov. 9 , 1997 detailing the cause of the incident and outlined corrective actions that included (1) Revision of written procedures to clearly describe measures to ensure control of surveyed material from licensed facilities prior to completion of State confirmatory surveys, and (2) Physical access 
controls and posting of "hold areas" for material awaiting confirmatory surveys. The corrective actions were implemented on Dec. 1, 1997 and Nov. 14, 1997 respectively. DHS responded, accepting the proposed corrective actions on Nov. 17, 1997. Survey documentation for this building debris confirms that no contaminated material left the site as a result of this event. 
Table 3-2. 1997 Agency Inspections/Visits Related to Environmental Remediation

\begin{tabular}{|c|c|c|c|}
\hline Date & Agency & Subject Area & Results \\
\hline January 1997 & $\begin{array}{l}\text { Dept. of Toxic Substances } \\
\text { Control }\end{array}$ & $\begin{array}{c}\text { Soil Sampling \& Well Location } \\
\text { Review - SSFL }\end{array}$ & No NOVs \\
\hline January 1997 & Dept. of Health Services & $\begin{array}{l}\text { Review/Exchange of Ambient } \\
\text { Radiation Monitors - SSFL }\end{array}$ & No NOVs \\
\hline February 1997 & DTSC & RFI Location Review -SSFL & No NOVs \\
\hline February 1997 & Dept. of Health Services & $\begin{array}{c}\text { Area IV Rad Survey Status } \\
\text { Review - SSFL }\end{array}$ & No NOVs \\
\hline March 1997 & DHS/RHB & 4020 Debris Inspection - SSFL & No NOVs \\
\hline April 1997 & DTSC & RFI Location Review - SSFL & No NOVs \\
\hline April 1997 & Dept. of Health Services & $\begin{array}{l}\text { Review/Exchange of Ambient } \\
\text { Radiation Monitors - SSFL }\end{array}$ & No NOVs \\
\hline April 1997 & VCAPCD & $\begin{array}{l}\text { ETEC/Demo Closure Asbestos } \\
\text { Project - SSFL }\end{array}$ & No NOVs \\
\hline May 1997 & DTSC & RFI Location Review - SSFL & No NOVs \\
\hline May 1997 & DOE & $\begin{array}{c}\text { Review of ETEC Waste } \\
\text { Management Program - SSFL }\end{array}$ & No NOVs \\
\hline June 1997 & DTSC & RFI Location Review - SSFL & No NOVs \\
\hline July 1997 & DTSC & RFI Location Review - SSFL & No NOVs \\
\hline July 1997 & Dept. of Health Services & $\begin{array}{c}\text { Review/Exchange of Ambient } \\
\text { Radiation Monitors - SSFL }\end{array}$ & No NOVs \\
\hline August 1997 & EPA & $\begin{array}{c}\text { Sampling of Monitoring Well in } \\
\text { Area IV and Brandies/Bardin - } \\
\text { SSFL }\end{array}$ & No NOVs \\
\hline August 1997 & DHS & Resurvey of 4020 Blocks & $1 \mathrm{NOV}$ \\
\hline September 1997 & DTSC & RFI Location Review - SSFL & No NOVs \\
\hline September 1997 & EPA & $\begin{array}{l}\text { Facility Inspection (EPA Program } \\
\text { Head) - SSFL }\end{array}$ & No NOVs \\
\hline September 1997 & DHS & $\begin{array}{l}\text { Confirmatory Inspections for } \\
4654, \text { RIHL, \& Blocks - SSFL }\end{array}$ & No NOVs \\
\hline October 1997 & DTSC & RFI Location Review - SSFL & No NOVs \\
\hline October 1997 & Dept. of Health Services & $\begin{array}{l}\text { Review/Exchange of Ambient } \\
\text { Radiation Monitors - SSFL }\end{array}$ & No NOVs \\
\hline November 1997 & DTSC & RFI Location Review - SSFL & No NOVs \\
\hline November 1997 & LAFD & $\begin{array}{l}\text { Fire Dept. Inspection of Business } \\
\text { Plan - DeSoto }\end{array}$ & No NOVs \\
\hline December 1997 & DTSC & RFI Location Review - SSFL & No NOVs \\
\hline
\end{tabular}

NOV $=$ Notice of Violation 


\subsection{CURRENT ISSUES AND ACTIONS}

\subsubsection{Progress in Decommissioning Operations}

Hot Lab (4020)

Decommissioning of the former Hot Lab proceeded during 1997. The basement of the facility was removed, and, after radiological survey to verify the area as "clean", the excavation was backfilled with clean fill dirt. (A marker bed consisting of one foot of sand was used to separate the fill from the native soil in case future identification is necessary). The basement complex was gradually demolished, and clean and contaminated debris was segregated to permit effective disposal of waste. Concrete saw cutting was used to section the basement into manageable blocks. Uncontaminated blocks were set aside for disposal as conventional waste after inspection and approval by the DHS/RFBB. Since no neutron activation occurred in the Hot Lab, release of blocks occurred if they met surface contamination limits. Contaminated blocks were transferred to another facility for further: cleaning. Removal of the below grade liquid waste treatment tank building occurred in 1998 and completed the demolition of the Hot Lab facility.

A major administrative change was made by the termination of the NRC Special Nuclear Materials license, SNM-21, to permit the work to be carried out under DOE regulations and orders. This termination was approved by NRC on September 27, 1996.

\section{Soil}

The contaminated soil areas were excavated in 1997. Final surveys and sampling for release are to be conducted in 1998.

4032

The below grade sodium drain tank was removed and cleaned using the wet vapor nitrogen process. The sodium components (piping, valves, test vessels etc.) were removed from the building and cleaned using water vapor nitrogen. All sodium components have been removed from the building.

4026

Two below grade sodium drain tanks were removed from the facility and cleaned using the wet vapor nitrogen process. Demolition of the extensive sodium piping system was begun. Components removed were cleaned using the wet vapor nitrogen process. The remaining sodium piping will be removed in 1998 and the facility core tank will be cleaned in place using the water vapor nitrogen process. After cleaning the core tank will be removed and all sodium system components will have been removed from the building. The building is scheduled for complete demolition. 
Cleaning in place of the Reaction Products Tank using the wet vapor nitrogen process was completed in 1997. The tank will remain in place until demolition of the building proceeds to a point where access to the tank is possible.

\section{$17^{\text {th }}$ Street Drainage}

Additional monitoring of areas within Area IV detected slightly elevated radiation levels in the $17^{\text {th }}$ Street drainage area. Subsequent soil sampling indicated localized Cesium 137

contamination up to a maximum of $14.9 \mathrm{pCi} / \mathrm{g}$, over the cleanup standard of $9.2 \mathrm{pCi} / \mathrm{g}$. In 1998 a characterization survey of the area was performed and the area was successfully remediated. DOE and the DHS were informed and will participate in the final survey and release process planned for 1999 .

\subsubsection{Epidemiological Study}

In 1993 the University of California, Los Angeles was hired by the California Department of Health Services with funds provided by the Department of Energy to perform an epidemiology study of Rocketdyne's radiation workers.

The title of the study is "Epidemiology Study to Determine the Possible Adverse Effects of Rocketdyne/Atomics International Workers from Exposure to Ionizing Radiation"(Ref. 12). The final report of the study was released September 11, 1997.

The study's conclusion alleged that radiation had caused excessive cancers in the radiation worker cohort. Understandably, this resulted in interest by the media and renewed concern among both the neighboring community and Rocketdyne's employees. However, an objective inspection of the study's data and results showed that very little of UCLA's conclusions were actually supported by the data. According to many national experts (Refs. 13, 14, 15 and 16), the study was replete with flawed methodology, including small numbers and associated statistical imprecision; selective cancer grouping; double and triple counting of deaths; inappropriate use of lung dose as a surrogate for exposure to all cancer sites; contradictory lung cancer conclusions; data dredging; inadequate treatment of confounders; throwing out data on prior occupational radiation exposure; and throwing out much of the data when calculating attributable risk.

Following an objective review of the UCLA study, national experts said that the following conclusions may be drawn from the study's data and results.

- Rocketdyne radiation workers have a $32 \%$ lower death rate from "all causes" and a $21 \%$ lower death rate from "all cancers" than the U.S. population

- Rocketdyne radiation workers have a $38 \%$ lower death rate from "all causes" and an $11 \%$ lower death rate from "all cancers" than a similar worker control group that was not exposed to occupational radiation

- UCLA concluded that there was an increased rate of leukemia/lymphoma in those workers with external exposure above $200 \mathrm{mSv}$ ( $20 \mathrm{rem}$ ). This conclusion was based 
on 1 leukemia death and 1 non-radiosensitive "Hodgkin's Disease" death among 34 workers with exposure above $200 \mathrm{mSv}$ ( $20 \mathrm{rem}$ ). The small sample size means that a large uncertainty is associated with this result.

- UCLA concluded that there was an increased rate of lung cancer in those workers with external exposure above $200 \mathrm{mSv}$ ( $20 \mathrm{rem}$ ). This was due to 2 lung cancer deaths among 34 workers with exposure above $200 \mathrm{mSv}$ ( $200 \mathrm{rem}$ ). The small sample size means that a large uncertainty is associated with this result. This result was also in direct contradiction to results for internal (inhaled) radiation exposure which showed decreasing lung cancer rates with increasing internal (lung) exposures

- Rocketdyne and many national experts in radiation effects and radiation epidemiology have questioned all UCLA's conclusions based on internal radiation exposure. UCLA's conclusions are not consistent with what has been seen in a majority of other worker studies that examined higher exposures and larger study groups

- Rocketdyne radiation workers have received lower exposures than any other group of radiation workers studied in the U.S., United Kingdom and Canada

- No Rocketdyne radiation worker has ever exceeded the allowable annual regulatory limits for external exposure

- Since 1984 , Rocketdyne has voluntarily limited annual exposures to less that $40 \%$ of regulatory limits

- The study demonstrates that Rocketdyne's efforts to minimize risks to its employees in the area of radiation protection have been successful

Any scientific study stands or falls based on extensive peer review by experts in the field. The Rocketdyne Worker Health Study is no exception. Numerous comments and critiques were received by Rocketdyne from both solicited and unsolicited peer reviewers. Taken as a whole, peer reviewer comments are severely critical of the methodology, analysis, interpretation of data, and conclusions of the study. The expertise of peer reviewers includes radiation epidemiology, radiation effects on A-bomb survivors, radiation oncology and health effects on humans, statistics, public health policy, health physics and radiation regulation.

Further information on the study may be obtained by calling (800) 808-1160. UCLA is currently working on the chemical exposure phase of the study and expects to release that report before the end of 1998.

\subsubsection{Resource Conservation and Recovery Act}

Under the Hazardous and Solid Waste Amendments of 1984, RCRA facilities can be brought into the corrective action process when an agency is considering any RCRA permit action for the facility. The SSFL was initially made subject to the corrective action process in 1989 by EPA, Region IX. The EPA has performed the Preliminary Assessment Report (i.e., record search) and the Visual Site Inspection portions of the RCRA Facility Assessment process. 
The State of California DTSC has RCRA authorization and has become the lead agency in implementing the corrective action process for the SSFL. ETEC has performed soil sampling at various SWMUs and Areas of Concern that were identified in the RFA report. This has enabled ETEC to determine if further action and/or interim measures will be necessary for SWMUs to be incorporated into the RCRA Facility Investigation. 


\subsubsection{Permits and Licenses (Area IV)}

Listed below are the permits and licenses applicable to activities in Area IV ${ }^{1}$. $\underline{\text { Air (VCAPCD) }}$

Permit

0271

Treatment Storage (EPA)

CAD000629972

(93-3-TS-002)

CA3890090001

NPDES (CRWOCB)

CA0001309

Nuclear Regulatory Agency

SNM-21

Hot Laboratory (T020)

Facility (T133 and T029)

Radioactive Materials Handling

Facility (RMHF)

Santa Susana Field Laboratory

6/29/98-5/10/03

Part A

interim status

updated $4 / 93$

Valid

$1 / 1 / 97-12 / 31 / 97$

Combined permit renewal

$11 / 30 / 93-11 / 30 / 03$

Terminated

9/27/96

State of California

Radioactive Materials

License (0015-70)
All Rocketdyne facilities

Amendment 92 issued $1 / 24 / 96$

ongoing

'The waste discharge requirements for the sewage treatment plant in Area III that receives the Area IV sewage are included in the NPDES permit. 
During 1997 there were 11 underground storage tanks that are exempt from permitting in Area IV. A list of the remaining tanks is shown in Table 3-3.

Table 3-3. SSFL Current Underground Storage Tanks

\begin{tabular}{|c|c|c|c|c|}
\hline UST & $\begin{array}{c}\text { Building } \\
\text { Location }\end{array}$ & $\begin{array}{c}\text { Capacity } \\
\text { (gallons) }\end{array}$ & Tank Type & Contents \\
\hline UT-7 & T022 & 3,000 & Stainless Steel Vaulted & RA watera \\
UT-15 & T022 & 8,000 & Stainless Steel Vaulted & RA watera \\
UT-16 & T021 & 200 & Stainless Steel Vaulted & RA watera \\
UT-24 & T059 & 12,000 & Stainless Steel Vaulted & Sodium \\
UT-29 & T356 & 13,000 & Stainless Steel Vaulted & Sodium \\
UT-30 & T356 & 10,000 & Stainless Steel Vaulted & Sodium \\
UT-31 & T356 & 10,000 & Stainless Steel Vaulted & Sodium \\
UT-32 & T356 & 10,000 & Stainless Steel Vaulted & Sodium \\
UT-33 & T356 & 12,000 & Stainless Steel Vaulted & Sodium \\
UT-34 & T462 & 36,000 & Stainless Steel Vaulted & Sodium \\
UT-35 & T462 & 34,000 & Stainless Steel Vaulted & Sodium \\
\hline
\end{tabular}

${ }^{2}$ Radioactive (RA) water tanks are regulated by U.S. Department of Energy (DOE).

bodium tanks are exempt from UST permitting per Ventura County Environmental Health Division 


\section{ENVIRONMENTAL PROGRAM INFORMATION}

At SSFL, the Energy Technology Engineering Center has responsibility for the former nuclear facilities and related cleanup operations. ETEC's Environmental Management (EM) Department is responsible for environmental restoration and waste management operations in Area IV, where the nuclear operations were conducted. The Department's mission is to "Perform remediation of the ETEC facilities with full regulatory compliance, total regard for personnel safety and protection of the environment, within agreed to budgets and schedules." Supporting the EM department in this work are ETEC's General Support \& QA Department and Rocketdyne's Safety, Health \& Environmental Affairs (SHEA), Transportation, Quality Assurance, Procurement, and Technical Skills Development Departments.

Environmental restoration activities at ETEC include decontamination and decommissioning of radioactively contaminated facilities, assessment and remediation of soil and groundwater, surveillance and maintenance of work areas, and environmental monitoring. Waste management activities include waste characterization and certification, storage, treatment, and offsite disposal. Waste management activities are performed at two permitted facilities; the Radioactive Materials Handling Facility for radioactive and mixed waste, and the Hazardous Waste Management Facility for alkali metal waste.

\subsection{ROCKETDYNE ENVIRONMENTAL PROTECTION AND REMEDIATION}

Oversight of the environmental protection at Rocketdyne is the responsibility of the SHEA Department, and this department provides support to ETEC for environmental management and restoration. The stated policy of this Department is "To support the Corporation's commitment to the well-being of its employees, community and environment. It is Rocketdyne's policy to maintain facilities and conduct operations in accordance with all federal, state and local requirements and contractual agreements. Rocketdyne employees are responsible for implementing and complying with this policy." Responsibilities for environmental protection at Rocketdyne fall under two sub-departments: Environmental Protection and Environmental Remediation. The responsibilities for each are listed below.

Environmental Protection (EP) is responsible for developing and implementing cost effective and efficient programs designed to ensure achievement of the policy objectives related to environmental protection. EP's responsibilities include:

- Ensuring compliance with applicable federal, state, and local rules and regulations, including maintaining a working knowledge of applicable environmental laws, performing compliance audits, reviewing new and modified facility projects, coordinating solid and hazardous waste disposal, maintaining required records, preparing and submitting required regulatory reports, applying for and maintaining permits and assuring compliance with permit conditions, performing sampling and analysis. 
- Responding to uncontrolled releases, and reporting releases as required by law and contractual requirements.

- Suspending operations determined to be in violation of environmental regulations.

- Participating in rule and regulatory development, including evaluating impacts on Rocketdyne programs, coordinating with other Rocketdyne functions, as appropriate, and informing management and staff of new or revised requirements.

- Providing a program, in conjunction with Technical Skills and Development, for motivating, informing and training employees about their duties to comply with environmental regulations and protect the environment.

- Recognizing and responding to the community's concerns regarding the environmental impact of Rocketdyne operations including escorting and cooperating with regulatory officials interested in environmental matters and responding to requests for information referred to Communications.

- Working with Rocketdyne customers and suppliers to minimize the use of materials and processes that impact the environment while maintaining product quality and competitive pricing.

- Making environmental concerns, energy and raw material conservation a priority when evaluating new and existing operations and products or when making decisions regarding land use, process changes, materials purchases, and business acquisitions.

Environmental Remediation (ER) is responsible for remedial actions to clean up historical chemical contamination and for providing radiological support for the D\&D of radiological contamination at all Rocketdyne facilities. ER's responsibilities include:

- Compliance with all federal, state and local regulations pertaining to environmental remediation.

- Remediation of historical chemically and radiologically contaminated Rocketdyne sites to achieve closure or permit release for use without radiological restrictions.

- Compliance with all federal, state and local regulations pertaining to occupational and environmental (ionizing) radiation protection.

- Provision of health physics oversight of D\&D and radioactive waste management activities.

- Performance of final surveys of D\&D'ed buildings and facilities to demonstrate acceptability for release for unrestricted use.

- Response to employee and public concerns regarding environmental remediation activities and the impact of these activities on the health and safety of the community. 


\subsection{ENVIRONMENTAL MONITORING PROGRAM}

The purpose of the environmental monitoring program is to detect and measure releases of hazardous and radioactive materials and identify other undesirable impacts on the environment. It includes remediation efforts to correct or improve contaminated conditions at the site and prevent offsite effects. For this purpose, the environment is sampled and monitored, and effluents are analyzed. A goal of this program is to demonstrate compliance with applicable regulations and protection of human health and the environment. Environmental restoration activities at the SSFL include a thorough review of past programs and historical practices to identify, characterize, and correct all areas of potential concern. The key regulations governing the monitoring program are DOE Orders 5400.1 and 5400.5 (Refs. 17 and 18). Additional guidance is drawn from California regulations and licenses, and appropriate standards.

The basic policy for control of radiological and chemical materials requires that adequate containment of such materials be provided through engineering controls, that facility effluent releases be controlled to federal and state standards, and that external radiation levels be reduced to as low as reasonably achievable (ALARA) through rigid operational controls. The environmental monitoring program provides a measure of the effectiveness of these operational procedures and of the engineering safeguards incorporated into facility designs.

\subsubsection{Radiological Monitoring}

The radiological monitoring program involves measurements of radioactivity in air, soil, surface water, ground water, and vegetation, and environmental and facility radiation, as appropriate to the changing conditions at the site.

Samples of particulate matter in facility ventilation exhausts and the ambient air are collected by means of filters and vacuum purnps. Facility atmospheric effluent sample filters and ambient air sample filters for 1997 were composited from each sampler for radiochemistry analysis by Brown Engineering. Gamma-spectrometry analyses of samples such as soil, water, and ambient air sample filters confirm that the major radionuclides present are normally those of the naturally occurring thorium and uranium decay chains, plus other natural radionuclides such as the primordial $\mathrm{K}-40$, and $\mathrm{Be}-7$ produced by cosmic ray interactions in the atmosphere.

In addition to environmental monitoring, workplace air and atmospheric effluents are continuously monitored or sampled, as appropriate. This directly measures the effectiveness of engineering controls and allows remedial action to be taken before a significant release of radioactivity could occur.

\subsubsection{Non-Radiological Monitoring}

Extensive monitoring programs for chemical contaminants in air, soil, surface water, and groundwater are in effect to assure that the existing environmental conditions do not pose a threat to the public welfare or environment. Soils contaminated by petroleum products are remediated whenever underground fuel tanks are removed. Extensive soil sampling is performed under the 
Resource Conservation and Recovery Act Facility Investigation and other site-specific remedial programs. Groundwater beneath Area IV is extensively monitored for chemical contaminants through sampling at 45 onsite and offsite wells. Groundwater analyses are conducted by Groundwater Resources Consultants, Inc. (GRC) following a DTSC-approved sampling and analysis plan and approved EPA analytical methods. Equipment installed in an interim groundwater remediation program has the capacity to remove solvents from contaminated groundwater at a throughput of eighty thousand gallons per month. This system returns remediated water to the surface water collection ponds.

All surface water discharges are monitored as specified in the existing National Pollutant Discharge Elimination System permit. In addition, all sources of emissions are monitored as required by the Ventura County Air Pollution Control District. Asbestos control is conducted under the requirements of Titles 29, 40, and 49 of the Code of Federal Regulations (CFR), in addition to any state or local regulations that apply to any specific asbestos abatement program.

In addition to this environmental monitoring and restoration program, current operational procedures reflect Rocketdyne's commitment to a clean and safe environment. For example, solvents and oils are collected and recycled, rather than being discarded. A comprehensive training and employee awareness program is in place. All employees working with hazardous materials are required to attend a course on hazardous materials waste management. Environmental bulletins are printed in the internal Rocketdyne newspaper to promote environmental awareness among all employees.

\subsection{ENVIRONMENTAL TRAINING}

Rocketdyne conducts training and development programs as an investment in human resources to meet both organizational and individual goals. These programs are aimed toward improving employee performance, assuring employee proficiency, preventing obsolescence in employee capability, and preparing employees for changing technology requirements and for possible advancement.

The People \& Communications Department is responsible for the development and administration of formal training and development programs. Line managers are responsible for individual employee development through formal training, work assignments, coaching, counseling, and performance evaluation. Line managers and employees are jointly responsible for defining and implementing individual training development goals and plans, including On the Job Training.

The Rocketdyne Technical Skills Department currently maintains a listing of approximately 700 courses available for Rocketdyne personnel. Of these, approximately 90 relate to environment, health, and safety, with approximately 40 relating to environmental protection and remediation. Specialized training programs on new technological developments and changes in regulations are provided, as needed, to assure effective environmental protection. 
Also, informal discussions about waste minimization and management occur at hazardous waste coordinator's meetings. Additional offsite courses are also encouraged.

\subsection{WASTE MINIMIZATION AND POLLUTION PREVENTION}

\subsubsection{Program Planning and Development}

A Waste Minimization and Pollution Prevention Awareness Plan developed in accordance with DOE Order 5400.1 (Ref. 17) has been in place since December 1993. The plan was updated (Ref. 19) during 1996 to include DOE's guidelines for waste minimization during ER activities. This plan serves as a guidance document for all waste generators at ETEC. The plan emphasizes ETEC's proactive policy of waste minimization and pollution prevention, and outlines goals, processes, and waste minimization techniques to be considered for all waste streams generated at ETEC. The plan requires that waste minimization assessments of all major restoration projects be performed.

The majority of waste currently generated at ETEC is attributable to environmental management activities related to environmental restoration of surplus facilities and clean up of contaminated sites from previous programs. Small amounts of hazardous waste are also generated as a result of ongoing test operations. The key components of waste generated at ETEC are:

- Low-level radioactive waste (LL,W), mixed, hazardous, and non-hazardous wastes from decontamination and decommissioning operations.

- Scrap metal resulting from the treatment of sodium contaminated metal components by the WVN process. (The sodium hydroxide produced by the WVN process is recycled). The sodium-contaminated components are from D\&D operations and ongoing test operations at ETEC.

- Motor/turbine oils from ongoing test operations.

- Solvents and paints.

In general, the measures used to promote waste minimization at ETEC are:

- Using comprehensive segregation and screening procedures to minimize mixed wastes by separating LLW and hazardous wastes.

- Using survey and decontamination processes to release concrete and steel for potential recycling/reuse

- Removal of bulk sodium from facility drain tanks for recycling/reuse.

- Conversion of residual sodium in piping and components to high grade sodium hydroxide for commercial use 
- Sampling, analyzing, and filtering oils to extend their useful life and reduce oil consumption.

- Reusing containers.

- Linking of a chemical/material exchange system with the purchasing system to reduce purchases of hazardous materials.

- Reducing non-hazardous waste disposal through process changes and recycling.

- Use/operation of improved air filtration technology in decontamination facility to minimize generation of filter media wastes.

Waste minimization is accomplished by first assessing the waste, identifying waste minimization options, and finally conducting technical and economic evaluations to determine the best approach.

The following ETEC Procedures supplement the Waste Minimization Plan.

- Rocketdyne System of Procedures C-101 Safety, Health and Environmental Affairs Program

- ETEC Procedure 2-11, Construction Management

- ETEC Procedure 2-30, Management of Real Property Maintenance Program

- ETEC Procedure 2-44, ETEC Self-Assessment Program

\subsubsection{Training and Awareness Programs}

The ETEC Waste Minimization and Pollution Prevention Awareness Program includes (1) orientation programs and refreshers, (2) specialized training, and (3) incentive awards and recognition. New ETEC employees attend an orientation program that describes waste generation, treatment, disposal, minimization, and pollution prevention. Orientation presentations are designed to increase pollution prevention and waste minimization awareness and to motivate employees.

Employees are reminded about pollution prevention and waste minimization awareness. Posters are placed in work areas to notify employees about environmental issues or practices. Memoranda are circulated about changes in waste management policy, ETEC and Rocketdyne policies or procedures, and technical data relevant to an employee's job assignment. Presentations using visual aids are provided, as needed, to review major changes in environmental issues. 


\subsubsection{Waste Minimization and Pollution Prevention Activities}

The following are some of the significant activities related to waste minimization and pollution prevention.

- Perform sampling, analysis, and filtering of motor/turbine oils prior to servicing. These procedures have greatly extended the life of these oils and saved money particularly when synthetic oils are involved.

- Use of comprehensive segregation and screening procedure of RA materials resulting in the salvage of usable non-radioactive scrap metal.

- A chemical/material exchange system is currently linked to the purchasing system and prevents the unnecessary purchase of hazardous materials.

- All hazardous waste containers in acceptable condition are reused. Similar hazardous wastes are combined during pickup runs.

- Use of spray nozzles for rinsing operations at the HWMF resulting in reducing the amount of water and hence generation of sodium hydroxide waste.

- Empty product drums returned to the vendor for reuse when practical.

- Approximately $80 \%$ of the white paper (5.51 metric tons) and aluminum cans (2.76 metric tons) are recycled as a result of increased environmental awareness.

- Use of a compactor to reduce the volume of soft low level radioactive waste with 5 to 15 compaction ratios (soft trash limited to 2 boxes; 18 contaminated 55 -gal drums compacted into one $65 \mathrm{cft}$ box).

- Size reduction and repackaging achieved significant radioactive waste reduction. Laser cutting reduced 14 boxes to 3 boxes of waste.

- Operation of a Torit self-cleaning filter unit in a radiological decontamination facility eliminated waste consisting of about 120 used pre-filters annually that would have been generated using a conventional unit.

- Approximately 55,000 pounds of residual sodium in tanks and piping systems was converted into commercial grade sodium hydroxide using a Water Vapor Nitrogen process. This resulted in avoiding generation of approximately 32,000 gallons of hazardous waste.

- Approximately 58 metric tons of clean recyclable stainless steel,327 metric tons of carbon steel, 9.4 metric tons of copper, and 750 pounds of lead resulted from divestment activities

- Cost effective decontamination practices resulted in 5.25 metric tons of recyclable steel, 1 metric ton of lead, and 240 cubic feet of excess equipment. 
- Implementation of the waste minimization assessment for the D\&D of the Helium Analysis Laboratory Building 104 at De Soto) resulted in the reduction in radioactive waste. By decontamination and surveys, a total of 7,100 cubic feet of potential waste was reduced to 3,900 cubic feet of low level waste.

- Implementation of the waste minimization assessment for the D\&D of the Hot Lab (4020) resulted in the reduction (by decontamination and survey) of 16,200 cubic feet of low level radioactive waste at a savings of about $\$ 206,000$.

\subsubsection{Tracking and Reporting System}

ETEC and Rocketdyne track various categories of materials from procurement to waste disposal. Wastes are tracked by various Rocketdyne and ETEC departments. Radioactive and mixed wastes are characterized by the generator, shipped to the Radioactive Materials Handling Facility, and logged and temporarily stored at the RMHF. Documents that accompany the wastes are verified for accuracy and completeness, and filed at the RMHF by Environmental Management personnel. Hazardous waste tracking and verification procedures (from generator to final offsite disposal) are followed by the Rocketdyne Environmental Protection Department. Rocketdyne is responsible for all non-hazardous and sanitary waste operations at the SSFL.

Relevant reports include:

- EPA's Biennial Hazardous Waste Report

- DOE's Annual Waste Minimization Report

- DOE's Affirmative Procurement Report

- "Source Reduction Evaluation Review and Plan" and "Hazardous Waste Management Performance Report," both of which are required by the "Source Reduction and Hazardous Waste Management Review Act (SB14)" 


\section{ENVIRONMENTAL RADIOLOGICAL MONITORING}

Radiological monitoring of the envirorment at SSFL began before the first nuclear facilities were established in 1956 . The program has continued with modifications to suit the changing operations. The selection of monitoring locations was based on several site-specific parameters such as topography, meteorology, hydrology, and the location of nuclear facilities. The prevailing wind direction for the SSFL site is generally from the north and northwest, with some seasonal diurnal shifting to the southeast quadrant. Most rainfall runoff at the SSFL site flows through several natural watercourses and drainage channels and is collected in two largecapacity retention ponds. This water may be discharged offsite into Bell Creek to the south or it may be reused for industrial purposes.

Gross alpha and beta measurements of air filter samples are used for screening purposes to quickly identify any unusual release, and to permit a long-term historical record of radioactivity in the environment. For surface water and groundwater, these measurements also permit direct comparison with the gross alpha and gross beta screening limits established by EPA for suppliers of drinking water. These gross radioactivity limits provide for more detailed analysis if exceeded. Ventilation exhaust and ambient air samples are counted for gross alpha and beta radioactivity and are also analyzed for specific radionuclides. Detailed analyses of these samples permit more accurate estimates of the potential offsite dose for the air pathway. The following discussion presents a brief summary of pathway dose analysis results for SSFL and De Soto for 1997.

Direct radiation is monitored by the use of 59 of thermoluminescent dosimeters (TLDs) mounted on facility fencelines and along the site boundary. To permit the most accurate measurement of low levels of ambient radiation, 18 of these are very sensitive "sapphire" TLDs. These TLDs are complemented by TLDs installed by the State of California Department of Health Services Radiologic Health Branch for independent surveillance. Additional standard TLDs are located around and throughout the facilities.

\subsection{DOE FACILITIES AT SSFL (AREA IV)}

The RMHF, Hot Lab, 4024, and 4059 have continuous effluent monitoring capability. In 1997, effluent was monitored only for the RMHF, 4024 and the Hot Lab, since there was no radiological work in 4059 during the year. The decontamination of several buildings was completed. Building 4005 was released for unrestricted use by the DHS/RHB in 1996 and was demolished in 1997. 4064 was released for clemolition by the DOE in 1996 and the demolition was carried out in 1997. Airborne releases from the RMHF Table 5-1, Sheet 1, and are shown to be below the Derived Concentration Guides (DCGs) of DOE Order 5400.5 (Ref. 18). Airborne radiation doses from the RMHF, 4024 and the Hot Lab are detailed in Table 5-1 and are shown to be below the dose limits of DOE Order 5400.5 and EPA NESHAPs limits of 40 CFR 61, Subpart $\mathrm{H}$. Key results are discussed below. 
At the site boundary-line location nearest to the RMHF, the external annual exposure from direct radiation is calculated to correspond to an average annual dose of approximately $48 \mathrm{mrem}$ above natural background (equivalent to $5.5 \mu \mathrm{R} / \mathrm{hr}$ ). An annual dose of $0.00017 \mathrm{mrem}$ is similarly calculated for the nearest residence. These values are below the DOE long-term limit of $100 \mathrm{mrem} / \mathrm{yr}$ as specified in DOE Order 5400.5 "Radiation Protection of the Public and the Environment." State and NRC regulations impose the same limits for licensed operations.

These calculated doses were determined by extrapolating the measured annual doses from various area dosimeters in place around the facility. Details on these calculations are given in Section 5.5. The boundary-line exposure is a conservative estimate of a hypothetical potential dose, in that the rugged terrain at the site boundary nearest the RMHF and the Hot Lab precludes anything more than the possible rare and temporary presence of any person at that location. For the nearest residence, radiation attenuation by the air reduces direct radiation to levels indistinguishable from normal background. In addition, intervening irregular rock formations and hills completely shield offsite locations from the radiation sources. Essentially only natural background radiation inherent to the residence location would actually be present.

Airborne dose calculations were performed to demonstrate compliance with the NESHAPs standard. At the location of the hypothetical Maximally Exposed Individual, the effective dose equivalent from DOE facility exhausts during 1997 (RMHF and 4024) was $2.7 \times 10^{-6}$ mrem. For the Hot Lab, detailed analysis of the stack monitoring filters showed no manmade isotopes, so there was no exposure to calculate. During 1997 the Hot Lab was demolished so this will be the final year for which a stack exhaust derived dose is calculated. The EPA limit for a DOE site is $10 \mathrm{mrem} / \mathrm{yr}$, as specified in $40 \mathrm{CFR}$ 61, Subpart $\mathrm{H}$. Potential releases from these facilities are so low that, even assuming absence of HEPA filters, estimated doses would be below the level requiring continuous monitoring. However, continuous monitoring is still being performed as a best management practice.

In addition to the above point sources, analyses were performed to determine the maximum estimated individual dose due to potential releases from "area" sources. The only area sources considered for 1997 are the 4064 sideyard and adjacent areas, the Hot Lab soil excavation area, and the RMHF pond (Sump 614), which was dry during part of 1997 and so was subject to possible resuspension of sediment by the wind. The RMHF north slope has been considered to be an occasional source in prior years but is now fully covered by native vegetation, and thus no wind borne resuspension of radioactively contaminated soil can occur. In 1997, expanded sampling of the Area IV survey plan indicated an area of low level soil contamination designated the $17^{\text {th }}$ Street Drainage Area. Throughout 1997 this area was covered with dense brush and was not considered to be a release point for radioactivity. Remediation of this area commenced in 1998.

The estimated dose to the hypothetical maximum exposed individual due to potential releases from the diffuse area sources only is $1.55 \times 10^{-4}$ mrem for 1997 . Since releases from the area sources were too small and diffuse to permit accurate measurements, potential releases were estimated using the same method used in the RESRAD (Ref. 20) computer program (ANL/ES160 ), for calculation of airborne radioactivity due to resuspension of soil by the wind. These 
estimated releases were used as input in the CAP88-PC program to perform the area source dose assessments. Releases from these sources have not been detected by onsite continuous ambient air sampling except for the Hot Lab, where detailed analysis of the north sampler filter set indicated $13.2 \mathrm{pCi} / \mathrm{g}$ of $\mathrm{Cs}-137$, which is why it was included in the area source dose calculations.

Airborne releases from the Hot Lab are detailed in Table 5-1, Sheet 2, and are shown to be below the DCGs of DOE Order 5400.5. The gross alpha and beta numbers were shown to be due to natural activity by the detailed laboratory analysis.

At the boundary-line location nearest to the Hot Lab, the external annual exposure from direct radiation is calculated to be approximately $0.002 \mathrm{mrem}$ above natural background (equivalent to $2.28 \times 10^{-4} \mu \mathrm{R} / \mathrm{hr}$ ). An annual dose of $1.33 \times 10^{-7}$ mrem is similarly calculated for the nearest residence. These values are below the DOE long-term limit of $100 \mathrm{mrem} / \mathrm{yr}$ as specified in DOE Order 5400.5. Dose to the hypothetical maximally exposed individual from airborne effluent from the Hot Lab for the entire year is considered to be $0 \mathrm{mrem} / \mathrm{yr}$ since no man made isotopes were detected in the filter analysis. The basement at the Hot Lab was demolished in 1997 and the facility ventilation unit was shut down during the first week of May, 1997.

Building 4024 was used as a staging and decontamination area for the Hot Lab concrete blocks, earlier extracted from the building during remediation activities. A portable tent was set up with a portable HEPA ventilation system providing negative pressure inside the tent during block decontamination. This HEPA unit exhausted to the outside environment and was monitored in a manner similar to the monitoring done at facility stacks.

Airborne releases from 4024 are detailed in Table 5-1, Sheet 4, and are shown to be below the DCGs of DOE Order 5400.5. Airborne and direct radiation doses at the site boundary are included in Table 5-15 and are shown to be less than the dose limits of DOE Order 5400.5 and EPA NESHAPS limits of 40 CFR 61, Subpart $H$.

\subsection{STATE OF CALIFORNIA LICENSIED FACILITY AT DE SOTO-BUILDING 104}

Airborne releases from Building 104 at the De Soto facility are detailed in Table 5-1, Sheet 3, and are shown to be below the maximum permitted concentrations (MPCs) of State of California, California Code of Regulations (CCR) Title 17, Section 30253. Airborne and direct radiation doses at the site boundary are detailed in Table 5-17 and are shown to be less than the dose limits of State of California, CCR Title 17, Section 30253. (This facility was operated for DOE under a State of California license.)

Direct radiation measurements at De Soto were slightly above background measurements, both onsite and offsite. The annual external exposure from direct radiation is calculated to correspond to an average annual dose of approximately $0.08 \mathrm{mrem}$ above natural background (equivalent to $9.13 \times 10^{-4} \mu \mathrm{R} / \mathrm{hr}$ ). An annual dose of $0.06 \mathrm{mrem}$ is similarly calculated for the nearest resident. Airborne effluent from Building 104 was a factor of $10^{3}$ less than the isotopic MPCs for the State of California. Dose to the hypothetical maximally exposed individual from 
airborne effluent was $4.87 \times 10^{-6} \mathrm{mrem} / \mathrm{yr}$, which is less than the EPA NESHAPs limit of 10 mrem/yr from 40 CFR 61, Subpart H, for DOE facilities. Compliance with 40 CFR 61, Subpart I, applicable to licensed facilities, was demonstrated by using the COMPLY code at the simplest level.

\subsection{EFFLUENT MONITORING}

Workplace ventilation is provided in all areas where unencapsulated or unpackaged radioactive material is handled, such as in the Hot Lab decontamination project and in the decontamination and packaging rooms at RMHF (where equipment is decontaminated and radioactive waste is repackaged). This assures protection of the workers from inhalation of airborne radioactive material and prevents the spread of radioactive contamination into the adjacent clean areas. The ventilation exhaust is passed through HEPA filters before being discharged to the atmosphere, to prevent the release of airborne radioactivity. The filtered air generally contains lower levels of long-lived radioactivity than does ambient air from naturally occurring radionuclides in the atmosphere. Essentially all short-lived radioactivity in the air is caused by natural beryllium-7 and the naturally present radon daughters, which dominate the airborne activity.

The ventilation exhaust is sampled to measure the effluent radioactivity. Data from this sampling is used to demonstrate compliance with State RHB, DOE, and EPA (NESHAPs) standards. The U.S. EPA regulates airborne releases of radioactivity from DOE facilities under 40 CFR 61, Subpart H, and from licensed facilities under 40 CFR 61, Subpart I.

The only potential release of effluent radioactivity to uncontrolled areas is by way of filtered discharge of ventilation exhaust from the RMHF, the Hot Lab, 4059, 4024 tent, and Building 104, and occasional diffuse area sources. No contaminated liquids are discharged to uncontrolled areas. No activities involving radioactive materials were conducted in 4059 during 1997. The only diffuse area sources considered significant for 1997 are a temporarily dry runoff collection sump for the RMHF, suspended soil during excavation at the Hot Lab, and the slightly contaminated soil to the east of Building 4064. Brush has been cleared from this area to permit further survey work.

Effluents that may contain radioactive material are released at the Rocketdyne Propulsion $\&$ Power facilities as the result of operations performed under contract to DOE, and under the State of California Radioactive Material License 0015-19. The specific facilities are identified as the RMHF, 4059, 4024 and the Hot Lab at SSFL, and Building 104 at the De Soto complex.

The level of radioactivity contained in all atmospheric effluents is reduced to the lowest practical value by passing the effluents through certified HEPA filters. The effluents are sampled for particulate radioactive materials by means of continuously operating stack exhaust samplers at the point of release. In addition, stack monitors installed at the Hot Lab and the RMHF provide automatic alarm capability in the event 
of the release of particulate activity. The HEPA filters used for filtering atmospheric effluents are at least $99.97 \%$ efficient for particles $0.3 \mu \mathrm{m}$ in diameter.

The average concentration and total radioactivity, as gross alpha and gross beta activity, in atmospheric effluents to uncontrolled areas from the RMHF, the Hot Lab, 4024, and De Soto 104 are shown in Table 5-1. The total shows that no significant quantities of radioactivity were released in 1997. The gross alpha and gross beta counts are done shortly after the weekly stack sample is collected, to permit identification of any unusual release. These results include the naturally occurring radionuclides present in air, Be-7, K-40, and Po-210. Detailed analyses are performed on the entire sets of filter samples at the end of the year, to provide the greatest analytical sensitivity.

The isotopic composition of the radioactivity deposited on the nuclear facility exhaust air sampling filters, composited for the year, is also presented in Table 5-1. Gamma-emitting radionuclides were measured by using a high-resolution gamma spectrometer. All others were measured by using specific chemical separations followed by alpha or beta counting and electrolytic enrichment of tritium followed by liquid scintillation counting. Radionuclides that were reported as less than the method detection level are shown as "not detected" (ND). The Po210 collected on the Hot Lab filter is due to use of unfiltered bypass (ambient) air taken into the main exhaust system from the outside, which contains naturally occurring elements from the U238 decay chain in the environment. The $\mathrm{K}-40$ is due to the presence of this radionuclide in natural potassium of the airborne dust in the ambient air. Be-7 had decayed below the detection level by the time of the analysis. Materials used in operations conducted at the SSFL and De Soto sites are responsible for the fission/activation product radioactivity.

For each radionuclide detected, the laboratory calculates minimum detectable activity (MDA). This is the lowest activity that would be identified as "detected" with $95 \%$ confidence. For the purpose of comparing effluent releases, the laboratory MDA for the composited filters was converted to an equivalent annual release and is shown in the table as the release MDA.

The radioactivity results are also shown in Table 5-2, for comparison with ambient air. The effectiveness of the air cleaning systems is evident from the fact that the atmospheric effluents are less radioactive than is the ambient air with respect to gross alpha and gross beta.

The concentrations in the effluent at the exhaust stack for each facility are compared with appropriate limits for exposure of the public. The isotopic limits for DOE facilities are DCGs for exposure of the public for the most restrictive form of the radionuclide as specified in DOE Order 5400.5. Isotopic effluent limits for facilities with State of California-licensed activities are Effluent Concentration Limits (ECLs) for release to an unrestricted area for the most restrictive form of the radionuclide as specified in 10 CFR 20, Appendix B.

The most restrictive ECL (from CCR 17 or 10 CFR 20) or DCG for each radionuclide is shown in Column 2 in Table 5-2. (The natural radionuclide $\mathrm{K}-40$ is so uniformly present, and so 
rarely present in an enriched form, that no ECL or DCG has been developed for it.) These values refer to the permissible concentrations allowed by the State of California and the DOE for continuous exposure of the public. Note that, in all cases, for the exhaust air, the observed concentrations are far below the ECL and DCG. Furthermore, dilution and dispersion occur before the material reaches an unrestricted area, reducing the concentration in the public area. 
Table 5-1. Atmospheric Effluents to Uncontrolled Areas

(Sheet 1 of 4)

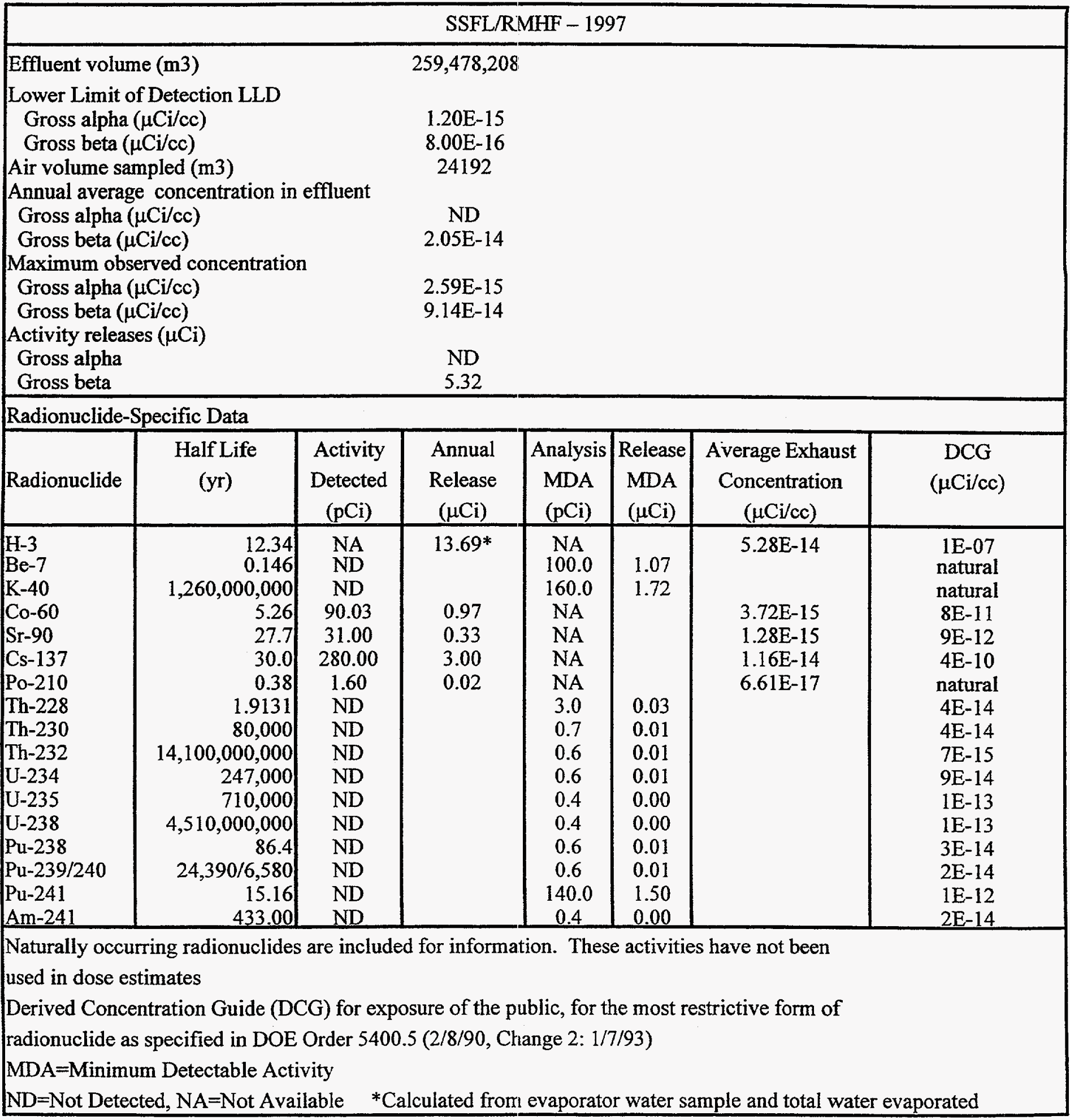


Table 5-1. Atmospheric Effluents to Uncontrolled Areas

(Sheet 2 of 4)

\begin{tabular}{|c|c|c|c|c|c|c|c|}
\hline & & & SFL/Hot L & boratory & -1997 & & \\
\hline Effluent volu & me (m3) & & $8,356,608$ & & & & \\
\hline Lower Limit & of Detection, & & & & & & \\
\hline Gross alpha & $(\mu \mathrm{Ci} / \mathrm{cc})$ & & $1.00 \mathrm{E}-15$ & & & & \\
\hline Gross beta ( & $\mu \mathrm{Ci} / \mathrm{cc})$ & & $3.30 \mathrm{E}-15$ & & & & \\
\hline Air volume se & impled (m3) & & 6739 & & & & \\
\hline Annual avera & ge concentration & in effluent & & & & & \\
\hline Gross alpha & $(\mu \mathrm{Ci} / \mathrm{cc})$ & & ND & & & & \\
\hline Gross beta ( & $\mu \mathrm{Ci} / \mathrm{cc})$ & & $4.08 \mathrm{E}-15$ & & & & \\
\hline Maximum ob & served concentrat & & & & & & \\
\hline Gross alpha & $(\mu \mathrm{Ci} / \mathrm{cc})$ & & $1.24 \mathrm{E}-15$ & & & & \\
\hline Gross beta ( & $\mathrm{i}(\mathrm{Ci} / \mathrm{cc})$ & & $1.04 \mathrm{E}-14$ & & & & \\
\hline Activity Rele & se $(\mu \mathrm{C} \mathbf{i})$ & & & & & & \\
\hline $\begin{array}{l}\text { Gross alpha } \\
\text { Gross beta }\end{array}$ & & & $\begin{array}{l}\text { ND } \\
0.03\end{array}$ & & & & \\
\hline Radionuclide & Specific Data & & & & & & \\
\hline Radionuclide & $\begin{array}{l}\text { Half Life } \\
\text { (yr) }\end{array}$ & $\begin{array}{c}\text { Activity } \\
\text { Detected } \\
\text { (pCi) }\end{array}$ & $\begin{array}{l}\text { Annual } \\
\text { Release } \\
(\mu \mathrm{Ci})\end{array}$ & $\begin{array}{l}\text { Analysis } \\
\text { MDA } \\
\text { (pCi) }\end{array}$ & \begin{tabular}{|c|} 
Release \\
$\mathrm{MDA}$ \\
$(\mu \mathrm{Ci})$
\end{tabular} & $\begin{array}{c}\text { Average Exhaust } \\
\text { Concentration } \\
(\mu \mathrm{Ci} / \mathrm{cc})\end{array}$ & $\begin{array}{c}\text { DCG } \\
(\mu \mathrm{Ci} / \mathrm{cc})\end{array}$ \\
\hline $\begin{array}{l}\text { Be-7 } \\
\text { K-40 } \\
\text { Co-60 } \\
\text { Sr-90 } \\
\text { Cs-137 } \\
\text { Po-210 } \\
\text { Th-228 } \\
\text { Th-230 } \\
\text { Th-232 } \\
\text { U-234 } \\
\text { U-235 } \\
\text { U-238 } \\
\text { Pu-238 } \\
\text { Pu-239/240 } \\
\text { Pu-241 } \\
\text { Am-241 }\end{array}$ & $\begin{array}{r}0.146 \\
1,260,000,000 \\
5.26 \\
27.7 \\
30.0 \\
0.38 \\
1.9131 \\
80,000 \\
14,100,000,000 \\
247,000 \\
710,000 \\
4,510,000,000 \\
86.4 \\
24390 / 6580 \\
15.16 \\
433.00 \\
\end{array}$ & $\begin{array}{l}\text { ND } \\
\text { ND } \\
\text { ND } \\
\text { ND } \\
3.60 \\
\text { ND } \\
\text { ND } \\
\text { ND } \\
\text { ND } \\
\text { ND } \\
\text { ND } \\
\text { ND } \\
\text { ND } \\
\text { ND } \\
\text { ND }\end{array}$ & 0.004 & \begin{tabular}{|c|}
60.000 \\
NA \\
7.0 \\
6.000 \\
6.000 \\
NA \\
0.995 \\
0.8 \\
0.7 \\
0.6 \\
0.4 \\
0.5 \\
0.7 \\
0.8 \\
97.3 \\
0.6 \\
\end{tabular} & \begin{tabular}{|c|}
0.074 \\
0.01 \\
0.01 \\
0.01 \\
\\
3.00 \\
0.60 \\
0.60 \\
0.50 \\
0.50 \\
0.50 \\
0.70 \\
0.90 \\
110.00 \\
0.40
\end{tabular} & $\begin{array}{l}1.22 \mathrm{E}-14 \\
5.34 \mathrm{E}-16\end{array}$ & $\begin{array}{l}\text { natural } \\
\text { natural } \\
8 \mathrm{E}-11 \\
9 \mathrm{E}-12 \\
4 \mathrm{E}-10 \\
\text { natural } \\
4 \mathrm{E}-14 \\
4 \mathrm{E}-14 \\
7 \mathrm{E}-15 \\
9 \mathrm{E}-14 \\
1 \mathrm{E}-13 \\
1 \mathrm{E}-13 \\
3 \mathrm{E}-14 \\
2 \mathrm{E}-14 \\
1 \mathrm{E}-12 \\
2 \mathrm{E}-14 \\
\end{array}$ \\
\hline $\begin{array}{l}\text { Naturally occ } \\
\text { been used in } \\
\text { Derived Conc } \\
\text { form of radior } \\
M D A=\text { Minim } \\
N D=\text { Not Dete }\end{array}$ & $\begin{array}{l}\text { uring radionuclid } \\
\text { ose estimates. } \\
\text { ntration Guide (1 } \\
\text { uclide as specifie } \\
\text { um Detectable } \mathrm{Ac} \\
\text { cted, } \mathrm{NA}=\mathrm{Not} \mathrm{Av}\end{array}$ & $\begin{array}{l}\text { les are inc } \\
\text { DCG) for } \\
\text { ed in DOE } \\
\text { ctivity } \\
\text { vailable }\end{array}$ & $\begin{array}{l}\text { osure o } \\
\text { der } 540\end{array}$ & $\begin{array}{l}\text { nation. } \\
\text { public, } \\
(2 / 8 / 90 \text {, }\end{array}$ & $\begin{array}{l}\text { These act } \\
\text { for the } m \\
\text { Change } 2\end{array}$ & $\begin{array}{l}\text { tivities have not } \\
\text { lost restrictive } \\
: 1 / 7 / 93 \text { ) }\end{array}$ & \\
\hline
\end{tabular}


Table 5-1. Atmospheric Effluents to Uncontrolled Areas

(Sheet 3 of 4)

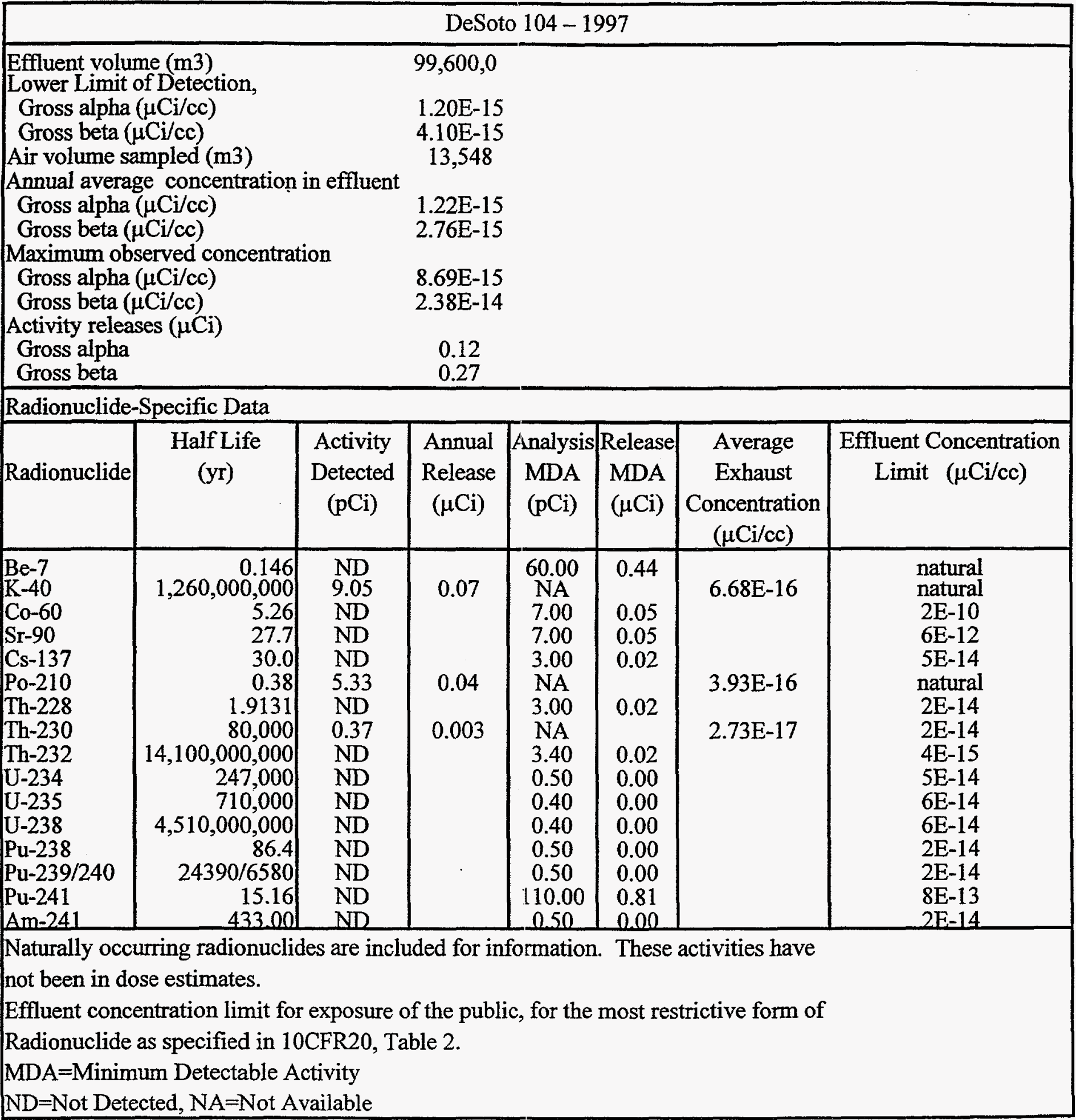


Table 5-1. Atmospheric Effluents to Uncontrolled Areas

(Sheet 4 of 4 )

\begin{tabular}{|c|c|c|c|c|c|c|c|}
\hline \multicolumn{8}{|c|}{ SSFL/4024- 1997} \\
\hline \multicolumn{3}{|c|}{ Effluent volume (m3) } & \multicolumn{5}{|l|}{$1,830,000$} \\
\hline \multicolumn{3}{|c|}{ Air volume sampled (m3) } & \multicolumn{4}{|l|}{307} & \\
\hline \multicolumn{8}{|c|}{ Radionuclide-Specific Data } \\
\hline Radionuclide & $\begin{array}{l}\text { Half Life } \\
\qquad(\mathrm{yr})\end{array}$ & $\begin{array}{c}\text { Activity } \\
\text { Detected } \\
\text { (pCi) }\end{array}$ & $\begin{array}{c}\text { Annual } \\
\text { Release } \\
(\mu \mathrm{Ci})\end{array}$ & $\begin{array}{c}\text { Analysis } \\
\text { MDA } \\
\text { (pCi) }\end{array}$ & $\begin{array}{c}\text { Release } \\
\text { MDA } \\
(\mu \mathrm{Ci})\end{array}$ & $\begin{array}{c}\text { Average Exhaust } \\
\text { Concentration } \\
(\mu \mathrm{Ci} / \mathrm{cc})\end{array}$ & $\begin{array}{c}D C G \\
(\mu \mathrm{Ci} / c c)\end{array}$ \\
\hline $\begin{array}{l}\text { Be-7 } \\
\text { K-40 } \\
\text { Co-60 } \\
\text { Sr-90 } \\
\text { Cs-137 } \\
\text { Po-210 } \\
\text { Th-228 } \\
\text { Th-230 } \\
\text { Th-232 } \\
\text { U-234 } \\
\text { U-235 } \\
\text { U-238 } \\
\text { Pu-238 } \\
\text { Pu-239/240 } \\
\text { Pu-241 } \\
\text { Am-241 }\end{array}$ & \begin{tabular}{r|r|}
0.146 \\
$1,260,000,000$ \\
5.26 \\
27.7 \\
30.0 \\
0.38 \\
1.9131 \\
80,000 \\
$14,100,000,000$ \\
247,000 \\
710,000 \\
$4,510,000,000$ \\
86.4 \\
$24390 / 6580$ \\
15.16 \\
433.00 \\
\end{tabular} & \begin{tabular}{|l} 
ND \\
ND \\
ND \\
ND \\
5.25 \\
ND \\
ND \\
ND \\
ND \\
ND \\
ND \\
ND \\
ND \\
ND \\
ND
\end{tabular} & 0.03 & \begin{tabular}{|c}
50.000 \\
70.000 \\
3.000 \\
4.000 \\
NA \\
0.200 \\
1.000 \\
0.300 \\
0.200 \\
0.200 \\
0.200 \\
0.200 \\
0.200 \\
0.200 \\
70.000 \\
0.300 \\
\end{tabular} & $\begin{array}{l}0.536 \\
0.751 \\
0.032 \\
0.043 \\
\\
0.002 \\
0.011 \\
0.003 \\
0.002 \\
0.002 \\
0.002 \\
0.002 \\
0.002 \\
0.002 \\
0.751 \\
0.003\end{array}$ & $1.71 \mathrm{E}-14$ & $\begin{array}{c}\text { natural } \\
\text { natural } \\
8 \mathrm{E}-11 \\
9 \mathrm{E}-12 \\
4 \mathrm{E}-10 \\
\text { natural } \\
4 \mathrm{E}-14 \\
4 \mathrm{E}-14 \\
7 \mathrm{E}-15 \\
9 \mathrm{E}-14 \\
1 \mathrm{E}-13 \\
1 \mathrm{E}-13 \\
3 \mathrm{E}-14 \\
2 \mathrm{E}-14 \\
1 \mathrm{E}-12 \\
2 \mathrm{E}-14 \\
\end{array}$ \\
\hline \multicolumn{8}{|c|}{$\begin{array}{l}\text { Naturally occurring radionuclides are included for information. These activities have not } \\
\text { been used in dose estimates. }\end{array}$} \\
\hline \multicolumn{8}{|c|}{$\begin{array}{l}\text { Derived Concentration Guide (DCG) for exposure of the public, for the most restrictive } \\
\text { form of radionuclide as specified in DOE Order } 5400.5(2 / 8 / 90 \text {, Change } 2.1 / 7 / 93)\end{array}$} \\
\hline \multicolumn{8}{|c|}{$\mathrm{MDA}=$ Minimum Detectable Activity } \\
\hline \multicolumn{8}{|c|}{$\mathrm{ND}=$ Not Detected, $\mathrm{NA}=$ Not Available } \\
\hline
\end{tabular}


Table 5-2. Filtered and Ambient Air Radioactivity Concentrations - 1997

\begin{tabular}{|c|c|c|c|c|c|c|c|c|c|c|c|c|c|c|c|c|c|c|}
\hline \multirow[b]{3}{*}{ Radionuclide } & \multirow[b]{3}{*}{$\begin{array}{c}\text { Derived } \\
\text { Concentration } \\
\text { Guide }\end{array}$} & \multirow[b]{3}{*}{$\begin{array}{c}{ }^{\star} \text { Effluent } \\
\text { Concentration } \\
\text { Limit }\end{array}$} & \multicolumn{16}{|c|}{ Activity Concentration $(\mu \mathrm{Ci} / \mathrm{mL})$} \\
\hline & & & \multicolumn{4}{|c|}{ Exhaust } & \multicolumn{10}{|c|}{ Ambient } & \multicolumn{2}{|c|}{ Averages } \\
\hline & & & RMHF & $\begin{array}{l}\text { Hot } \\
\text { Lab }\end{array}$ & DS104* & T024 & RMHF & $\begin{array}{l}\text { RMHF } \\
\text { Pond }\end{array}$ & $\begin{array}{l}\text { Hot } \\
\text { Lab }\end{array}$ & T100 & T886 & DS104* & $\begin{array}{c}\text { Fot } \\
\text { Lab } \\
\text { North }\end{array}$ & $\begin{array}{c}\text { Hot } \\
\text { Lab } \\
\text { South }\end{array}$ & $\begin{array}{l}\text { Hot } \\
\text { Lab } \\
\text { East }\end{array}$ & $\begin{array}{l}\text { Hot } \\
\text { Lab } \\
\text { West }\end{array}$ & Exhaust & Ambient \\
\hline $\mathrm{H}-3$ & $1 \mathrm{E}-07$ & IE-07 & $5.3 \mathrm{E}-14$ & & & & & & & & & & & & & & $5.3 \mathrm{E}-14$ & \\
\hline $\mathrm{Be}-7$ & Natural & Natural & & & & & & & & $2.6 \mathrm{E}-14$ & & & $5.7 \mathrm{E}-14$ & $8.1 \mathrm{E}-14$ & $6.8 \mathrm{E}-14$ & $3.4 \mathrm{E}-14$ & & $5.3 \mathrm{E}-14$ \\
\hline $\mathrm{K}-40$ & Natural & Natural & & $1.2 \mathrm{E}-14$ & $6.7 \mathrm{E}-16$ & & $2.1 \mathrm{E}-15$ & & & & & $8.5 \mathrm{E}-16$ & & $3.4 \mathrm{E}-14$ & & & $6.5 \mathrm{E}-15$ & 1.2E-14 \\
\hline $\mathrm{Co}-60$ & $8 \mathrm{E}-11$ & $5 \mathrm{E}-11$ & $3.7 \mathrm{E}-15$ & & & & & & & & & & & & & & $3.7 \mathrm{E}-15$ & \\
\hline Sr-90 & $9 \mathrm{E}-12$ & $6 \mathrm{E}-12$ & $1.3 \mathrm{E}-15$ & & & & & & & & & & & & & & $1.3 \mathrm{E}-15$ & \\
\hline Cs- 137 & $4 \mathrm{E}-10$ & $2 \mathrm{E}-10$ & $1.2 \mathrm{E}-14$ & & & $1.7 \mathrm{E}-14$ & & & & & & & $7.8 \mathrm{E}-15$ & & & & $1.4 \mathrm{E}-14$ & $7.8 \mathrm{E}-15$ \\
\hline Po-210 & Natural & Natural & $6.6 \mathrm{E}-17$ & $5.3 \mathrm{E}-16$ & $3.9 \mathrm{E}-16$ & & $8.4 \mathrm{E}-15$ & $3.7 \mathrm{E}-15$ & $5.1 \mathrm{E}-15$ & $5.5 \mathrm{E}-15$ & $3.8 \mathrm{E}-15$ & $3.5 \mathrm{E}-15$ & $9.45-15$ & $|7.1 \mathrm{E}-15|$ & $9.75-15$ & $8.2 \mathrm{E}-15$ & $3.3 \mathrm{E}-\mathrm{i} 5$ & $6.4 \mathrm{E}-15$ \\
\hline Th-228 & $4 \mathrm{E}-14$ & $2 \mathrm{E}-14$ & & & & & & & & & & & & & & & & \\
\hline Th-230 & $4 \mathrm{E}-14$ & $2 \mathrm{E}-14$ & & & $2.7 \mathrm{E}-17$ & & & & $1.8 \mathrm{E}-16$ & & $3.1 \mathrm{E}-16$ & $1.2 \mathrm{E}-16$ & $1.9 \mathrm{E}-16$ & & & & $2.7 \mathrm{E}-17$ & $2.0 \mathrm{E}-16$ \\
\hline Th-232 & $7 \mathrm{E}-15$ & $4 \mathrm{E}-15$ & & & & & & & & & $1.5 \mathrm{E}-16$ & & & & & & & $1.5 \mathrm{E}-16$ \\
\hline U-234 & $9 \mathrm{E}-14$ & $5 \mathrm{E}-14$ & & & & & & & & & & & & & & & & \\
\hline$U-235$ & $1 \mathrm{E}-13$ & $6 \mathrm{E}-14$ & & & & & & & & & & & & & & & & \\
\hline U-238 & $1 \mathrm{E}-13$ & $6 \mathrm{E}-14$ & & & & & $1.3 \mathrm{E}-16$ & & & & & & & & & & & $1.3 \mathrm{E}-16$ \\
\hline $\mathrm{Pu}-238$ & $3 \mathrm{E}-14$ & $2 \mathrm{E}-14$ & & & & & & & & & & & & & & & & \\
\hline $\mathrm{Pu}-239 / 240$ & $2 \mathrm{E}-14$ & $2 \mathrm{E}-14$ & & & & & & & & & & & & & & & & \\
\hline $\mathrm{Pu}-241$ & $1 \mathrm{E}-12$ & $8 \mathrm{E}-13$ & & & & & & & & & & & & & & & & \\
\hline$A m-241$ & $2 \mathrm{E}-14$ & $2 \mathrm{E}-14$ & & & & & & & & & & & & & & & & \\
\hline Gross Alpha & None & & ND & ND & 1.2E-15 & $\mathrm{NA}$ & $2.1 \mathrm{E}-15$ & $1.9 \mathrm{E}-15$ & $2.4 \mathrm{E}-15$ & $2.1 \mathrm{E}-15$ & $1.6 \mathrm{E}-15$ & $2.6 \mathrm{E}-15$ & $7.7 \mathrm{E}-15$ & $4.5 \mathrm{E}-15$ & $4.5 \mathrm{E}-15$ & $6.6 \mathrm{E}-15$ & $1.2 \mathrm{E}-15$ & $2.1 \mathrm{E}-15$ \\
\hline Gross Beta & None & & $2.1 \mathrm{E}-14$ & $1.4 \mathrm{E}-14$ & $2.8 \mathrm{E}-15$ & NA & $1.8 \mathrm{E}-14$ & $2.2 \mathrm{E}-14$ & $2.0 \mathrm{E}-14$ & $1.7 \mathrm{E}-14$ & $1.5 \mathrm{E}-14$ & $1.8 \mathrm{E}-14$ & $5.6 \mathrm{E}-14$ & $5.4 \mathrm{E}-14$ & $4.4 \mathrm{E}-14$ & $4.4 \mathrm{E}-14$ & $9.1 \mathrm{E}-15$ & $1.8 \mathrm{E}-14$ \\
\hline
\end{tabular}


The downwind concentration of radioactive material emissions to the atmosphere during 1997 from the RMHF exhaust stack and the 4024 tent exhauster has been calculated with the CAP88-PC computer code using representative input data including wind speed, directional frequency, and stability (using meteorological data developed for the SSFL site by the NRC and Argonne National Laboratory [ANL]) plus facility-specific data such as stack heights and exhaust air velocity.

The radioactivity concentrations at the site boundary location nearest to each release point and at the nearest residence for each nuclear facility are shown in Table 5-3. These concentrations were estimated by use of CAP88-PC and specific radionuclide releases for each facility, for the direction in which the concentrations are the greatest. Because of the close proximity of RMHF and 4024, they were treated as one source in the CAP88-PC calculations. While the site boundary is only 118 meters from the RMHF, the maximum ground level concentration occurs at a distance of 325 meters. Therefore, the concentration for the RMHF is calculated for this distance.

Table 5-3. Annual Average Radioactivity Concentrations of Atmospheric Effluents - 1997

\begin{tabular}{|c|c|c|c|c|c|}
\hline \multirow{2}{*}{ Facility } & \multirow{2}{*}{$\begin{array}{c}\text { Annual } \\
\text { Release } \\
(\mu \mathrm{Ci})\end{array}$} & \multicolumn{2}{|c|}{$\begin{array}{c}\text { Distance }(\mathrm{m}) \text { and } \\
\text { Direction to }\end{array}$} & \multicolumn{2}{|c|}{$\begin{array}{c}\text { Downwind Concentration } \\
(\mu \mathrm{Ci} / \mathrm{mL})\end{array}$} \\
\cline { 3 - 6 } & 0.003 & $187 \mathrm{E}$ & $315 \mathrm{~S}$ & $2.4 \mathrm{E}-21$ & $1.3 \mathrm{E}-21$ \\
\hline $\mathrm{DS} 104$ & & & & & \\
$\begin{array}{c}\mathrm{RMHF} \text { and } \\
4020\end{array}$ & 18.02 & $325 \mathrm{NW}$ & $2,867 \mathrm{NW}$ & $1.73 \mathrm{E}-18$ & $1.59 \mathrm{E}-19$ \\
\hline
\end{tabular}

\subsection{ENVIRONMENTAL SAMPLING}

\subsubsection{Air}

Ambient air sampling is performed continuously at De Soto and SSFL with air samplers operating on 7-day sampling cycles. In 1997, 4 additional samplers were operated on a shift by shift basis at the Hot Lab during soil excavation operations. Monitoring locations used in 1997 are shown in Figures 5-1 and 5-2 and listed in Table 5-4. Airborne particulate radioactivity is collected on glass fiber (Type A/E) filters that are changed weekly at the end of each sampling period. The samples are counted for gross alpha and beta radiation following a minimum 120 hour decay period to allow for decay of short-lived radon and thoron daughters. The volume of a typical weekly ambient air sample is approximately $50.4 \mathrm{~m}^{3}$.

Weekly ambient air samples are counted for gross alpha and beta radiation with a lowbackground thin-window gas-flow proportional-counting system. The system is capable of simultaneously counting both alpha and beta radiation. The sample-detector configuration provides a nearly hemispherical $(2 \pi)$ geometry. The thin-window detector is continually purged 
with argon/methane counting gas. A preset time mode of operation is used for counting all samples.

Counting system efficiencies are deternined routinely with Tc-99 and Th-230 standard sources. The activities of the standard sources are traceable to the National Institute of Standards and Technology (NIST).

Filter samples for each ambient air sampling location are composited annually and analyzed for isotopic-specific activity. The results of the sample analyses are shown in Table 5-2 with the effluent results for comparison. As is the case with effluent air samples, the observed ambient air radionuclide concentrations were far below the ECL and DCG values. The variability in the measurements was dominated by weather effects and by analytical and background variations. 


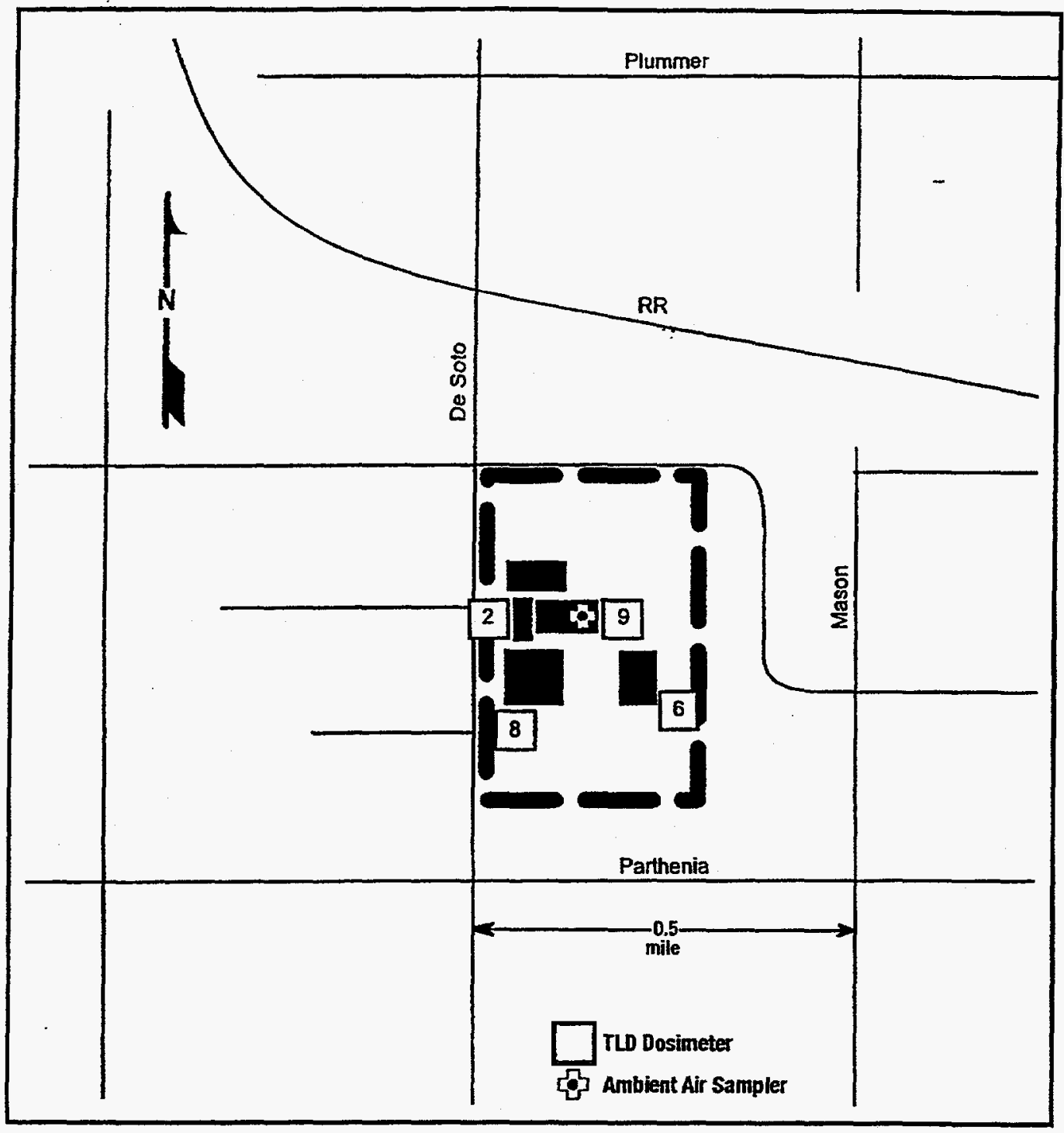

Figure 5-1. Map of De Soto Site Monitoring Stations 


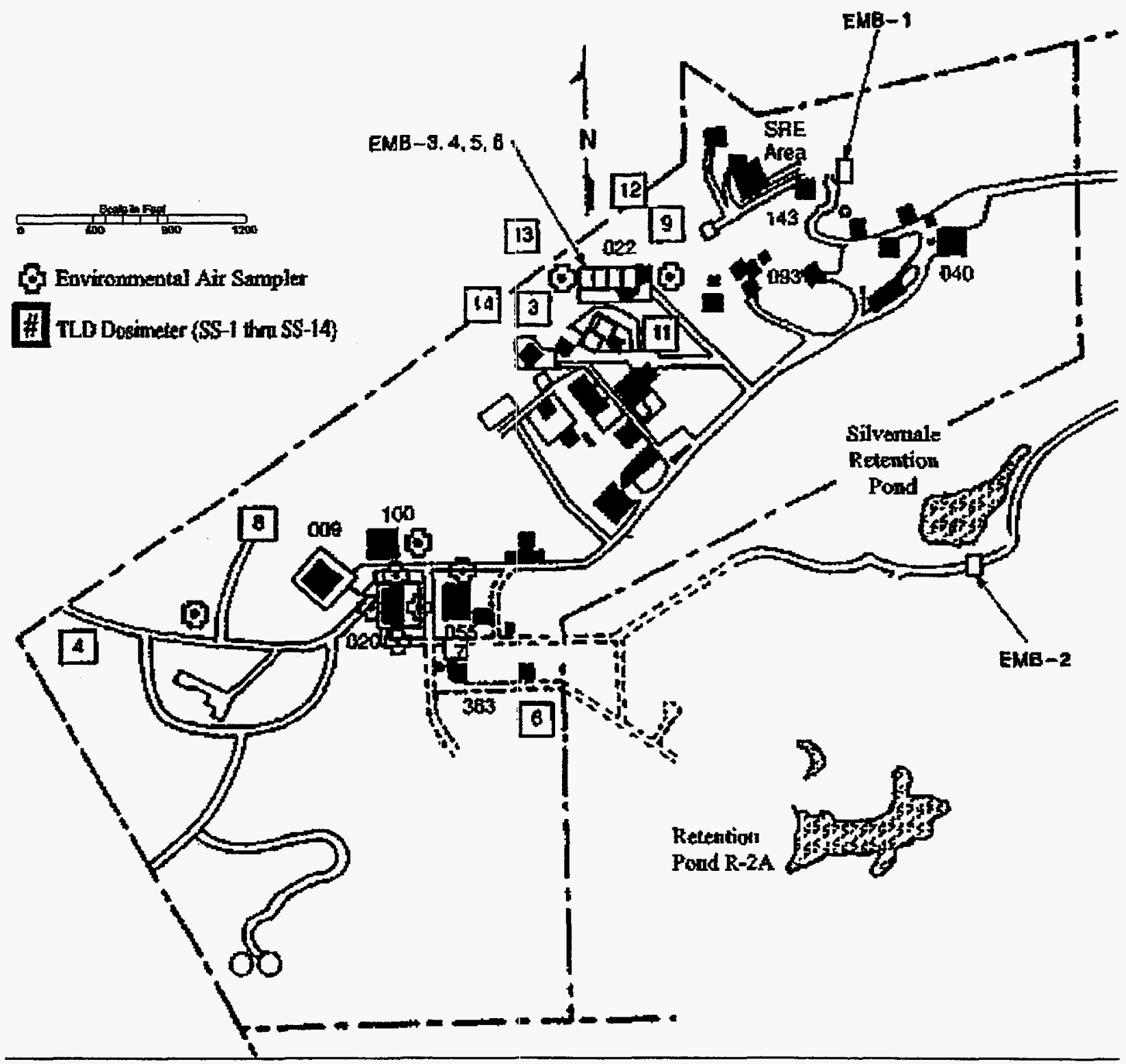

Figure 5-2. Map of Santa Susana Field Laboratory Area IV Sampling Stations 
Table 5-4. Sampling Location Description

\begin{tabular}{|c|c|c|}
\hline Station & Location & $\begin{array}{l}\text { Sampling } \\
\text { Frequency }\end{array}$ \\
\hline \multicolumn{2}{|c|}{\begin{tabular}{l|l} 
Ambient Air Sampler Locations, \\
A-1 \\
A-2 & De Soto Site, Building 104 roof \\
A-3 & SSFL Site, 4020, southwest side \\
A-4 & SSFL Site, 4034, at main gate \\
A-5 & SSFL Site, 4886, Former Sodium Disposal Facility \\
A-6 & SSFL Site, RMHF Pond, north side \\
A-7 & SSFL Site, 4100, east side - 7-day sampler \\
A-8 & SSFL Site, 4020, north side \\
A-9 & SSFL Site, 4020, south side \\
A-10 & SSFL Site, 4020, east side \\
& SSFL Site, 4020, west side
\end{tabular}} & $\begin{array}{l}(M) \\
(W) \\
(M) \\
(M) \\
(W) \\
(M) \\
M \\
M \\
M \\
(M) \\
(M)\end{array}$ \\
\hline \multicolumn{2}{|c|}{ 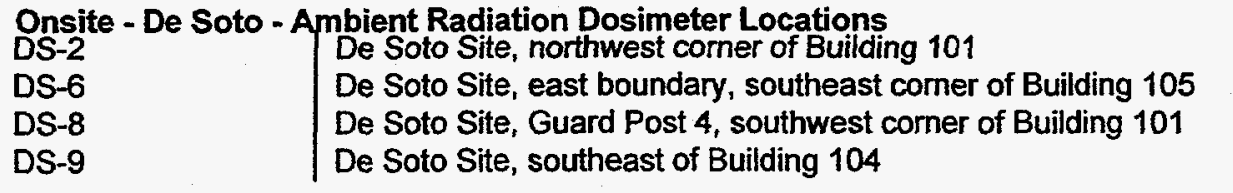 } & $\begin{array}{l}(Q) \\
(Q) \\
(Q) \\
(Q)\end{array}$ \\
\hline \multicolumn{2}{|c|}{$\begin{array}{ll}\text { Onsite -SSFL - Ambient Radiation Dosimeter Locations } \\
\text { SS-3 (CA) } & \text { SSFL Site, Electric Substation 719 on boundary fence } \\
\text { SS-4 (CA) } & \text { SSFL Site, west boundary on H Street } \\
\text { SS-6 (CA) } & \text { SSFL Site, northeast corner of } 4353 \\
\text { SS-7 (CA) } & \text { SSFL Site, 4363, north side } \\
\text { SS-8 (CA) } & \text { SSFL Site, Former Sodium Disposal Facility north boundary } \\
\text { SS-9 (CA) } & \text { SSFL Site, RMHF northeast boundary at } 4133 \\
\text { SS-11 (CA) } & \text { SSFL Site, 4036, east side } \\
\text { SS-12 (CA) } & \text { SSFL Site, RMHF northwest property line boundary } \\
\text { SS-13 (CA) } & \text { SSFL Site, RMHF northwest property line boundary } \\
\text { SS-14 (CA) } & \text { SSFL Site, RMHF northwest property line boundary } \\
\text { EMB-1 (CA) } & \text { SSFL Site, SRE area north of 4003 } \\
\text { EMB-2 (CA) } & \text { SSFL Site, south of Silvernale retention pond, off Test Area Road } \\
\text { EMB-3(CA) } & \text { SSFL Site, northeast fence of RMHF } \\
\text { EMB-4(CA) } & \text { SSFL Site, RMHF north central fenceline } \\
\text { EMB-5 (CA) } & \text { SSFL Site, RMHF northwest fenceline } \\
\text { EMB-6 (CA) } & \text { SSFL Site, RMHF 4075 north fenceline }\end{array}$} & $\begin{array}{l}(Q) \\
(Q) \\
(Q) \\
(Q) \\
(Q) \\
(Q) \\
(Q) \\
(Q) \\
(Q) \\
(Q) \\
(Q) \\
(Q) \\
(Q) \\
(Q) \\
(Q)\end{array}$ \\
\hline \multicolumn{2}{|c|}{\begin{tabular}{l|l} 
Offsite Ambient Ragiation Dosimeter Locations \\
OS-1 (CA) & Offsite, Chatsworth \\
OS-5 & Offsite, Thousand Oaks \\
BKG-11 & Background Location, West Hills \\
BKG-12 & Background Location, Somis \\
BKG-13 & Background Location, Hollywood \\
BKG-14 & Background Location, Northridge \\
BKG-15 & Background Location, Simi Valley (west) \\
BKG-16 & Background Location, Moorpark \\
BKG-17 & Background Location, Simi Valley (east) \\
BKG-19 & Background Location, Burbank \\
BKG-20 & Background Location, Lancaster \\
BKG-21 & Background Location, Quartz Hill \\
BKG-22 & Background Location, Saugus \\
BKG-23 & Background Location, Calabasas \\
\end{tabular}} & $\begin{array}{l}(\mathrm{Q}) \\
(\mathrm{Q}) \\
(\mathrm{Q}) \\
(\mathrm{Q}) \\
(\mathrm{Q}) \\
(\mathrm{Q}) \\
(\mathrm{Q}) \\
(\mathrm{Q}) \\
(\mathrm{Q}) \\
(\mathrm{Q}) \\
(\mathrm{Q}) \\
(\mathrm{Q}) \\
(\mathrm{Q}) \\
(\mathrm{Q})\end{array}$ \\
\hline $\begin{array}{l}\text { Codes: } \\
\text { A } \\
D \\
W \\
Q \\
\text { CA }\end{array}$ & $\begin{array}{l}\text { Air Sampler Station } \\
\text { Daily Sample } \\
\text { Weekly Sample } \\
\text { Quarterly Sample } \\
\text { State Confirmatory Location }\end{array}$ & \\
\hline
\end{tabular}


It should be emphasized that these measurements determine only the long-lived particulate radioactivity in the air and, therefore, do not show radon (Rn-222) and most of its daughter radionuclides. Polonium-210 is a long-lived daughter and is detected by these analyses. It is assumed to be in equilibrium with its parent, $\mathrm{Pb}-210$, whose relatively long half-life (22.3 years) provides an essentially constant level of Po-210 in the samples. Because of these effects, the ambient air, the air that is being breathed, is actually about four times as radioactive as implied in this table. Since most short-lived particulate radioactivity is removed from the exhaust air by the HEPA filters, these effects are not significant in the filtered effluent.

Because the alpha and beta activity are counted relatively soon after collection, most natural Be-7 is detected, elevating the apparent beta activity. (Be-7 decays by electron-capture and emits a gamma ray in $10 \%$ of the decays. This gamma ray is weakly detected as beta activity.) The naturally occurring radionuclides, Po-210 and Ra-226 and -228 , also contribute to the activity detected on the stack exhaust filter samples, particularly at the Hot Lab, where some unfiltered outside air is brought into the exhaust system after the HEPA filters. A more complete list of the results from the gross alpha and gross beta counting of the ambient air samples is shown in Table 5-5.

On four occasions the north and west Hot Lab samples exceeded the alpha DCG limits (West, $2.2 \times 10^{-14}$ on $11 / 4 / 97$ and $2.1 \times 10^{-14}$ on 10/7/97. North, $2.8 \times 10^{-14}$ on 10/7/97 and $2.1 \times$ $10^{-14}$ on 11/4/97). The DCG limits are based on annual averages and, as can be seen in Table 5-5, the averages for both sample sets are less than $40 \%$ of the limit. It should also be noted that $\mathrm{Pu}$ 239 is used as the guidance limit to be conservative. The detailed analysis of the filter sets indicated that no plutonium was present in the samples (see Table 5-2). The north filter set analysis indicated Th-230, at $1.9 \times 10^{-16} \mu \mathrm{Ci} / \mathrm{cc}$. The DCG for Th-230 is $4 \times 10^{-14} \mu \mathrm{Ci} / \mathrm{cc}$.

Guide values for SSFL site ambient air are based on the effluent concentration limits in 10 CFR 20 Appendix B (for licensed operations) and DOE Order 5400.5 for the DOE operations. The conservative guide value for alpha activity is $2 \times 10^{-14} \mu \mathrm{Ci} / \mathrm{mL}$. The appropriate value for beta activity is $9 \times 10^{-12} \mu \mathrm{Ci} / \mathrm{mL}$ ( $\mathrm{Sr}-90$ ) due to the presence of $\mathrm{Sr}-90$ in fission product contamination from previous work with irradiated nuclear fuel at the SSFL. The appropriate guide value for De Soto ambient air alpha activity is $2 \times 10^{-10} \mu \mathrm{Ci} / \mathrm{mL}$ (U-234) due to prior (licensed) work with unencapsulated enriched uranium. The appropriate guide value for beta activity is for Co-60, $5 \times 10^{-11} \mu \mathrm{Ci} / \mathrm{mL}$ since it is the most restrictive limit for any beta-emitting radionuclide recently in use at $\mathrm{De}$ Soto.

The activity detected in ambient air is attributed to naturally occurring radioactive materials. Radionuclides detected by gross alpha and beta analysis of air samples collected during 1997 include K-40 plus several naturally occurring radionuclides from the uranium and thorium series (see Table 5-2). 
Table 5-5. Ambient Air Radioactivity Data - 1997

\begin{tabular}{|c|c|c|c|c|c|}
\hline & & & \multicolumn{3}{|c|}{ Gross Radioactivity Concentrations $(\mu \mathrm{Ci} / \mathrm{mL})$} \\
\cline { 4 - 6 } Area & Activity & $\begin{array}{c}\text { Number } \\
\text { of } \\
\text { Samples }\end{array}$ & $\begin{array}{c}\text { Annual Average } \\
\text { Value and } \\
\text { Dispersion }\end{array}$ & $\begin{array}{c}\text { Maximum Valuea } \\
\text { and Date } \\
\text { Observed }\end{array}$ & $\begin{array}{c}\text { Average } \\
\text { Percent of } \\
\text { Guideb }\end{array}$ \\
\hline De Soto & Alpha & 45 & $(2.6 \pm 3.2) \mathrm{E}-15$ & $8.4 \mathrm{E}-15(10 / 29)$ & 5.2 \\
Building 104 & Beta & & $(18.1 \pm 8.5) \mathrm{E}-15$ & $71.9 \mathrm{E}-15(10 / 29)$ & 0.04 \\
\hline SSFL Area IV & Alpha & 48 & $(2.1 \pm 2.9) \mathrm{E}-15$ & $9.1 \mathrm{E}-15(12 / 3)$ & 10.5 \\
Hot Lab & Beta & & $(17.4 \pm 8.4) \mathrm{E}-15$ & $46.7 \mathrm{E}-15(9 / 3)$ & 0.19 \\
\hline SSFL Area IV & Alpha & 48 & $(2.1 \pm 2.9) \mathrm{E}-15$ & $10.0 \mathrm{E}-15(10 / 15)$ & 10.5 \\
RMHF & Beta & & $(18.4 \pm 8.6) \mathrm{E}-15$ & $77.3 \mathrm{E}-15(10 / 29)$ & 0.20 \\
\hline SSFL Area IV & Alpha & 48 & $(1.6 \pm 2.5) \mathrm{E}-15$ & $7.0 \mathrm{E}-15(7 / 23)$ & 8.0 \\
T886 & Beta & & $(14.9 \pm 7.7) \mathrm{E}-15$ & $42.7 \mathrm{E}-15(9 / 3)$ & 0.17 \\
\hline SSFL Area IV & Alpha & 48 & $(1.9 \pm 2.8) \mathrm{E}-15$ & $10.2 \mathrm{E}-15(12 / 3)$ & 9.5 \\
RMHF Pond & Beta & & $(16.2 \pm 8.1) \mathrm{E}-15$ & $52.3 \mathrm{E}-15(12 / 3)$ & 0.24 \\
\hline SSFL Area IV & Alpha & 27 & $(7.7 \pm 5.5) \mathrm{E}-15$ & $2.8 \mathrm{E}-14(10 / 7)$ & 38.5 \\
Hot Lab North & Beta & & $(5.6 \pm 4.7) \mathrm{E}-14$ & $2.3 \mathrm{E}-13(6 / 3)$ & 0.62 \\
\hline SSFL Area IV & Alpha & 27 & $(5.1 \pm 4.5) \mathrm{E}-15$ & $1.6 \mathrm{E}-14(10 / 7)$ & 25.5 \\
Hot Lab South & Beta & & $(5.4 \pm 2.8) \mathrm{E}-14$ & $1.9 \mathrm{E}-13(6 / 23)$ & 0.60 \\
\hline SSFL Area IV & Alpha & 23 & $(4.5 \pm 4.2) \mathrm{E}-15$ & $1.8 \mathrm{E}-14(10 / 7)$ & 22.5 \\
Hot Lab East & Beta & & $(4.4 \pm 4.2) \mathrm{E}-14$ & $1.6 \mathrm{E}-13(11 / 4)$ & 0.49 \\
\hline SSFL Area IV & Alpha & 27 & $(6.6 \pm 5.1) \mathrm{E}-15$ & $2.2 \mathrm{E}-14(11 / 4)$ & 33.0 \\
Hot Lab West & Beta & & $(4.4 \pm 4.2) \mathrm{E}-14$ & $1.4 \mathrm{E}-13(11 / 4)$ & 0.49 \\
\hline
\end{tabular}

aMaximum value observed for single sample.

bGuide De Soto Site: $5 \mathrm{E}-14 \mu \mathrm{Ci} / \mathrm{mL}$ alpha, $2 \times 10^{-10} \mu \mathrm{Ci} / \mathrm{mL}$ beta; CCR 17.

SSFL site: $2 \mathrm{E}-14 \mu \mathrm{Ci} / \mathrm{mL}$ alpha, $9 \mathrm{E}-12 \mu \mathrm{Ci} / \mathrm{mL}$ beta, DOE Order $5400.5(02 / 08 / 90)$.

\subsubsection{Groundwater}

Forty-five wells in and around Area IV used to monitor the condition of the groundwater in the unconsolidated surface alluvium and the underlying Chatsworth formation. The locations of these wells are shown in Figure 6-2. The purpose of these wells is to monitor concentrations of chemicals or radioactivity released by DOE operations. Water samples from these wells are periodically analyzed for radioactivity. The summary results for 1997 are shown in Table 5-6.

The regulatory limits for radioactivity in water from drinking water suppliers have been assigned to groundwater by the State of California as a water-quality goal, and are applied here. Numerical limits for radionuclides not specifically listed by the State for drinking water were derived from the EPA generic dose limit of $4 \mathrm{mrem} /$ year by use of Dose Conversion Factors from RESRAD version 5.61. Except for several instances for gross alpha ( 20 to $28 \mathrm{pCi} / \mathrm{L}$ ), the monitored groundwater satisfies the goal. The gross alpha limit exceedences resulted from the presence of higher levels of naturally occurring uranium. 
Groundwater is extracted from a French drain around a basement area of Building 4059 to prevent any inflow or outflow of groundwater into a part of the building currently undergoing remediation. During 1997, this water was released to the surface drainage water collection system. Samples were analyzed by gamma spectrometry. The results of these analyses showed no detectable activity for the remaining activation nuclides possible from 4059 . In no sample was any activity detected that indicated the possibility of contamination of this water.

Laboratory analyses were performed for tritium in water from 36 groundwater-monitoring wells and 4 offsite wells (See Figure 6.2). Of the 59 analyses performed, only 14 (all onsite wells) were above the method detection activity. The maximum result, $4,870 \mathrm{pCi} / \mathrm{L}$ in well $\mathrm{RD} 34 \mathrm{~A}$, is far below the EPA and California limits for drinking water suppliers of $20,000 \mathrm{pCi} / \mathrm{L}$. The maximum tritium levels were observed in Well $\mathrm{RD}-34 \mathrm{~A}$, with values of $4,870 \pm 500 \mathrm{pCi} / \mathrm{L}$. on $2 / 7 / 97$, and Well RD-50, with a value of $550 \pm 170 \mathrm{pCi} / \mathrm{L}$ on $5 / 5 / 97$. Well RD-34A is located on newly acquired land near the RMHF in Area IV. Well RD-50 is located southwest of Building 4009. RD-24, near 4059 showed $500 \pm 180 \mathrm{pCi} / \mathrm{L}(2 / 7 / 97)$ and $390 \pm 160 \mathrm{pCi} / \mathrm{L}$ (8/4/7). RD-28, also near 4059, showed $500 \pm 180 \mathrm{pCi} / \mathrm{L}(2 / 7 / 97)$ and $390 \pm 160 \mathrm{pCi} / \mathrm{L}(8 / 4 / 97)$. $\mathrm{RD}-54 \mathrm{~A}$ showed $430 \pm 150 \mathrm{pCi} / \mathrm{L}(5 / 59 / 97)$ and $370 \pm 160 \mathrm{pCi} / \mathrm{L}(8 / 22 / 97)$.

Figure 5-3 Tritium Concentration in Water From Well RD-34A

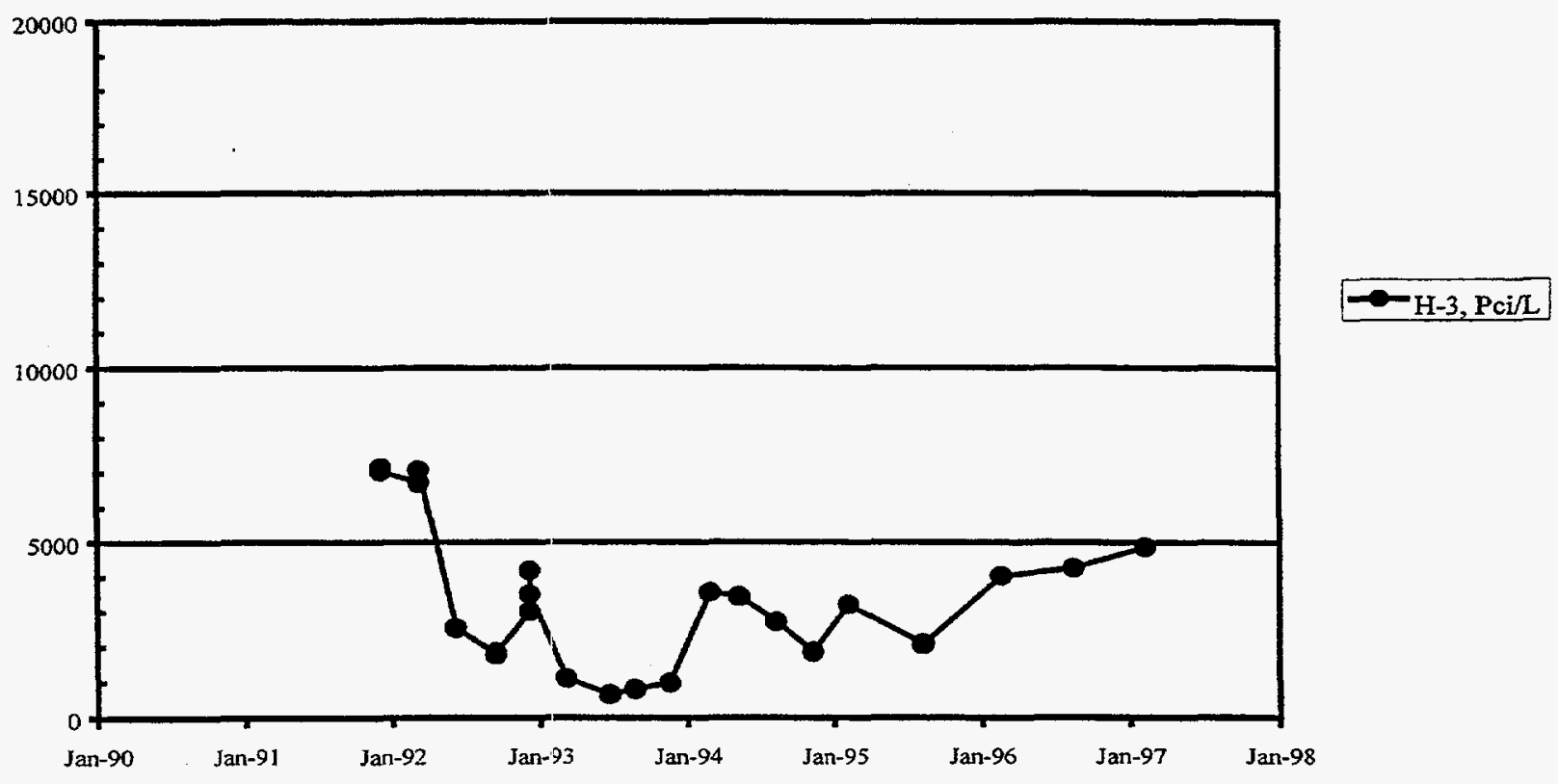


Other wells indicating detectable level of tritium were RS-11, RS-16, RS-18, ES-31, RD$18 \mathrm{RD}-21, \mathrm{RD}-23, \mathrm{RD}-25$, and $\mathrm{RD}-65$. The average detected tritium in the 14 wells was about $575 \mathrm{pCi} / \mathrm{L}$. Excluding the one well with the highest $\mathrm{H}-3$ content $(\mathrm{RD}-34 \mathrm{~A})$, the average was 250 $\mathrm{pCi} / \mathrm{L}$. The history of tritium concentration in water from Well RD-34A is shown in Figure 5-3. Full scale on this plot is $20,000 \mathrm{pCi} / \mathrm{L}$, the allowable limit for suppliers of drinking water. Since the initial detection of about $7000 \mathrm{pCi} / \mathrm{L}$, the well has ranged between 1000 and $5000 \mathrm{pCi} / \mathrm{L}$. None of the offsite wells showed the presence of tritium. This occurrence of tritium in groundwater appears to have resulted from unintended production of tritium in soil surrounding the reactor test vessel in Building 4010, shown as S8ER (4010) in Figure 2-5.

Table 5-6 Radioactivity in Groundwater at SSFL - 1997

\begin{tabular}{|l|c|c|c|c|c|c|c|c|c|c|c|}
\cline { 2 - 10 } \multicolumn{1}{c|}{} & \multicolumn{9}{c|}{ Activity (pCi/L) } \\
\cline { 2 - 10 } & H-3 & Cs-137 & Th-228 & Th-230 & Th-232 & U-234 & U-235 & U-238 & $\begin{array}{c}\text { Gross } \\
\text { Alpha }\end{array}$ & $\begin{array}{c}\text { Gross } \\
\text { Beta }\end{array}$ \\
\hline $\begin{array}{l}\text { Water Suppliers } \\
\text { MCL }\end{array}$ & $20,000^{2}$ & 110 & 6.8 & 10 & 2.0 & $20-$ Total Uranium & $15^{\mathrm{a}}$ & $50^{\mathrm{a}}$ \\
\hline Maximum & 4870 & $\mathrm{ND}$ & 0.1 & 0.009 & -0.009 & 16.6 & 0.86 & 15.6 & 28.0 & 17.3 \\
\hline Mean & 204 & $\mathrm{ND}$ & 0.1 & 0.009 & -0.009 & 10.8 & 0.51 & 9.9 & 8.29 & 6.3 \\
\hline Minimum & -80 & $\mathrm{ND}$ & 0.1 & 0.009 & -0.009 & 2.1 & 0.09 & 1.29 & -0.18 & 0.5 \\
\hline $\begin{array}{l}\text { Number of } \\
\text { Analyses }\end{array}$ & $59(42)$ & $51(51)$ & $1(1)$ & $1(1)$ & $1(1)$ & $8(0)$ & $8(0)$ & $8(0)$ & $\begin{array}{c}55 \\
(21)\end{array}$ & $\begin{array}{c}55 \\
(14)\end{array}$ \\
\hline
\end{tabular}

${ }^{\text {aFrom }}$ 40CFR141 and EPA limit of $4 \mathrm{mrem} / \mathrm{yr}$ (see text)

${ }^{b}$ Numbers in parentheses represent the number of analyses reported as less than the detectable limit. The mean has been calculated from all reported values. $\mathrm{ND}=$ not detected

\subsubsection{Surface Water and Domestic Water Supply}

Most of Area IV slopes toward the southeast, and rainfall runoff is collected by a series of drainage channels and accumulates in the R2A Pond. Water from this pond is eventually released to Bell Creek under the NPDES permit. Water from the R2A Pond is also used for cooling the rocket engine test stand flame buckets where much of the cooling water evaporates. Some of Area IV slopes to the northwest, and a small amount of rainfall drains toward the northwest ravines, which lead into Meier Canyon. To permit sampling this runoff, five catch basins were installed in 1989 near the site boundary to accumulate runoff.

Average radioactivity concentrations in these catch basin samples are summarized in Table 5-7. For radioactivity, the maximum contaminant limits (MCL) applicable to suppliers of 
drinking water (Title 22, Chapter 15, Article 5, Section 64443, of the California Code of Regulations) are imposed on releases from the two southern controlled discharge points (Outfalls 001 and 002) and the five northwest slope runoff channels (Outfalls 003, 004, 005, 006, and 007). Although not required if gross alpha does not exceed $5 \mathrm{pCi} / \mathrm{L}$, the specific analyses for $\mathrm{Ra}$ $226+\mathrm{Ra}-228$ were generally performed.

In none of the runoff events did any radiological analysis indicate an exceedance of these limits. Most results were below the detection capability of the analysis.

Table 5-7. NPDES Discharge Radioactivity Data for Northwest Slope Monitoring - 1997

\begin{tabular}{|l|c|c|c|c|c|c|}
\cline { 2 - 7 } \multicolumn{1}{c|}{} & \multicolumn{7}{c|}{ Activity (pCi/L) } \\
\cline { 2 - 7 } \multicolumn{1}{c|}{} & H-3 & Sr-90 & $\begin{array}{c}\text { Ra-226+ } \\
\text { R-228 }\end{array}$ & $\begin{array}{c}\text { Gross } \\
\text { Alpha }\end{array}$ & $\begin{array}{c}\text { Gross } \\
\text { Beta }\end{array}$ & Uranium \\
\hline $\begin{array}{l}\text { Water Suppliers } \\
\text { MCL }\end{array}$ & 20,000 & 8 & 5 & 15 & 50 & 20 \\
\hline Maximum & 250 & 1.15 & 1.3 & 2.6 & 8.2 & NA \\
\hline Mean & 116 & 0.28 & 0.6 & 1.1 & 3.5 & NA \\
\hline Minimum & -50 & 0.03 & 0.1 & 0.0 & 1.1 & NA \\
\hline $\begin{array}{l}\text { Number of } \\
\text { Analyses }\end{array}$ & $24(23)$ & $24(23)$ & $24(24)$ & $24(22)$ & $24(4)$ & \\
\hline
\end{tabular}

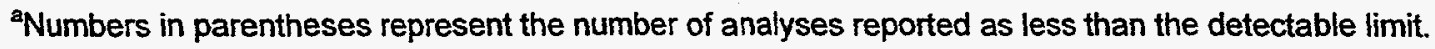

Domestic water in this area is supplied by a variety of municipal and regional organizations, including the Los Angeles Department of Water and Power, several Ventura County Waterworks Districts, and the Oxnard Public Works Department. Most of the water is imported from distant sources, such as Owens Valley, the Feather River, and the Colorado River. Some water, for Oxnard and Moorpark, comes from local groundwater wells. The local water is blended with imported water and treated to assure purity and safety. Water is transported in open aqueducts and enclosed pipelines and is stored in open reservoirs and underground settling basins. The State of California requires that these suppliers routinely monitor their water for many potentially hazardous materials (and less significant aesthetic quality factors, as well) and report the results of this monitoring to their customers on an annual basis. Tests for radioactivity are relatively limited, and are performed over an extended period of time, so not all parameters are reported in any one year. The results reported by local water suppliers during 1997 are shown in Table 5-8 and represent the averages of results of analysis of water supplied from the Los Angles Department of Water and Power (LADWP), Burbank, and the Ventura County Waterworks (District 1). 
Table 5-8. Domestic Water Supplies Radioactivity Data

\begin{tabular}{|l|c|c|c|c|c|c|}
\cline { 2 - 7 } \multicolumn{1}{c|}{} & \multicolumn{7}{c|}{ H-3 } & Sr-90 & $\begin{array}{c}\text { Ra-226+ } \\
\text { R-228 }\end{array}$ & $\begin{array}{c}\text { Gross } \\
\text { Alpha }\end{array}$ & $\begin{array}{c}\text { Gross } \\
\text { Beta }\end{array}$ & Uranium \\
\cline { 2 - 7 } & 20,000 & 8 & 5 & 15 & 50 & 20 \\
\hline $\begin{array}{l}\text { Water Suppliers } \\
\text { MCL }\end{array}$ & ND & ND & 1.0 & 8.9 & 8.9 & 8.3 \\
\hline Maximum & ND & ND & 0.8 & 4.2 & 5.8 & 4.0 \\
\hline Mean & ND & ND & 0.2 & 1.4 & 3.0 & 1.8 \\
\hline Minimum & $16(16)$ & $16(16)$ & $16(7)$ & $16(1)$ & $16(8)$ & $16(10)$ \\
\hline $\begin{array}{l}\text { Number of } \\
\text { reports }\end{array}$ & & & & & & \\
\hline
\end{tabular}

${ }^{a}$ Numbers in parentheses represent the number of report entries listed as not analyzed, not detected, or not reported.

Comparison of the radioactivity concentrations in groundwater at SSFL from Table 5-7 with that of the local public supply water (Table 5-8) shows no significant differences in either the alpha or beta activity.

\subsubsection{Rock and Soil}

The radioactivity in native rock and soil can serve as an indicator of any spread of contamination outside the operating facilities and other known areas of radioactive contamination. Soil radioactivity is due to various naturally occurring radionuclides present in the environment and to radioactive fallout of dispersed nuclear weapons materials. Naturally occurring radionuclides include $\mathrm{K}-40$ and the uranium and thorium series (including radon and daughters). The radionuclide composition of local area surface soil has been determined to be predominantly K-40, natural thorium, and natural uranium, both in secular equilibrium with daughter nuclides. Radioactivity in nuclear weapons test fallout consists primarily of the fissionproduced $\mathrm{Sr}-90$ and $\mathrm{Cs}-137$, as well as $\mathrm{Pu}-239$.

\subsubsection{Former Sodium Disposal Facility}

In 1997, soil was sampled by the DHS/RHB at the 4886 Former Sodium Disposal Facility as part of the verification that this area has been suitably decontaminated. These analyses showed minor amounts of Cs-137, below the global fallout concentration, and no Sr-90. No other contaminants were detected. After reviewing their data, the facility was released for unrestricted use in May of 1998.

\subsubsection{Interim Storage Facility}

Extensive sampling was also conducted at the 4654 Interim Fuel Storage Facility and adjacent area as part of the final survey and release process. The Interim Storage Facility was constructed in 1958 as auxiliary facility for the Sodium Reactor Experiment (SRE). A paved area $65 \mathrm{ft}$ by $40 \mathrm{ft}$ was fenced to establish a secure storage facility for the SRE and, subsequently, 
other projects. Below-grade storage was provided by eight cells extending $25 \mathrm{ft}$ deep into the ground and bedrock. The cells consisted of 20 -inch diameter pipes in 3-ft diameter holes. The annular space was filled with sand or drilling mud for stability. The top of each cell was sealed. The cell tops were effectively below grade level, in a concrete trench. At the end of life of the facility, this trench was open to the weather.

Radioactive materials were also stored in a variety of casks and containers in and adjacent to the fenced area constituting the facility. All such items were removed after 1981, and decommissioning was begun in 1984. Decornmissioning consisted of locating and removing surface contamination from the paving and the concrete structure of the below grade storage cells, and complete removal of the below grade structure. The excavation was backfilled with clean concrete rubble that had been surveyed to assure that only material with "no detectable activity" was put in the ground. (Review of documents in the 4654 decommissioning file showed that only the top of the concrete structure was contaminated and that, after scabbling to remove this contamination, the concrete showed readings that were the same as background, 75$100 \mathrm{cpm}$ with a pancake GM probe.) The excavation was then filled with the local soil that had been previously excavated, and the surface was graded to a natural form. A survey was performed throughout the area shown in Figure 5-4. This survey showed the facility to be acceptable for release for unrestricted use.

A review in 1995 by ORISE, the DOE Independent Verification Contractor (IVC), judged that the documentation of the original survey was inadequate by today's standards.

Shortcomings identified include the fact the contamination condition of concrete rubble used as backfill was not quantitatively documented in the report, and that the effectiveness of the qualitative gamma exposure rate survey was compromised by skyshine from radioactive material at nearby RMHF (then the Radioactive Materials Disposal Facility, RMDF). Further, at the time of the IVC review, the subsurface soil was not accessible for sampling.

A final survey and sampling plan for 4654 was developed and implemented in 1997. It consisted of a $100 \%$ gamma scan of the affected area with a sodium iodide detector, 93 surface soil samples taken in a standard $11 \%$ statistical method, and 12 sub-surface soil samples taken at the location of the original excavation. The locations of the samples are shown in Figure 5-4. Only gamma spectrometry was performed on these samples, and so only the gamma emitting radionuclides are identified for these locations. A cumulative probability plot of the 1997 results is shown in Figure 5-5. This plot clearly shows the departure from the background distribution of fallout Cs-137 just over the $50 \%$ point on the Cumulative Probability scale. The plot also shows that all of the samples are below the $9.2 \mathrm{pCi} / \mathrm{g}$ limit, as indicated by the "UL" line.

\subsubsection{Hot Lab}

During the demolition of the Hot Lab, 232 soil samples were taken for exploring the need to remediate contaminated soil and for pre-release of the facility. Only gamma spectrometry was performed on these samples, and so only the gamma emitting radionuclides are identified for these locations. A cumulative probability plot of the 1997 results is shown in Figure 5-6. This plot clearly shows the departure from the background distribution of fallout Cs-137 just under the $90 \%$ point on the Cumulative Probability scale. While most of the area is below the 
allowable contamination limit, $9.2 \mathrm{pCi} / \mathrm{gm}$ Cs-137, as shown by the "UL" line, all soil above the global fallout background level was excavated and packaged for disposal as radioactive waste. The results of these analyses are shown in Table 5-10 


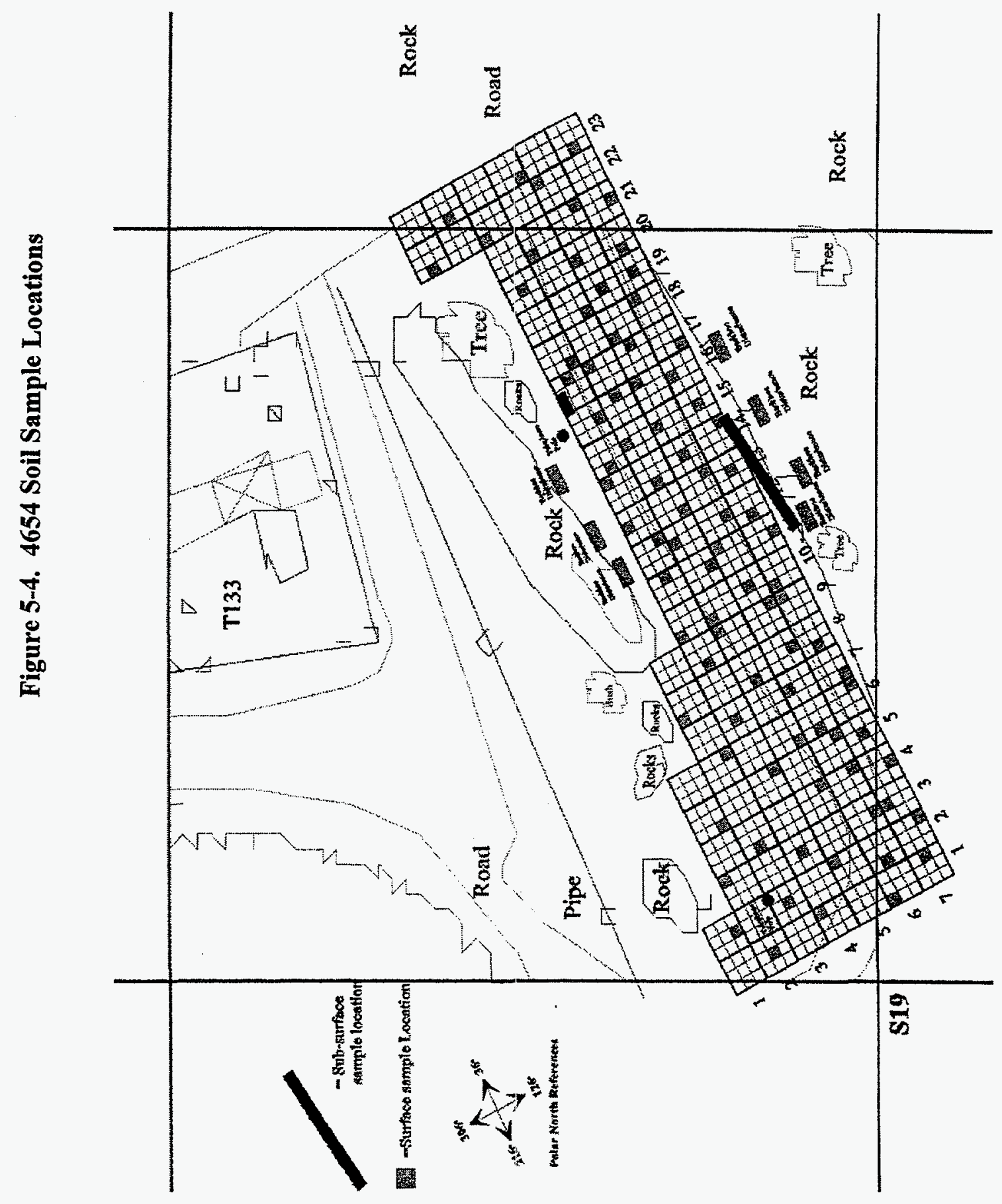

$\infty$ 


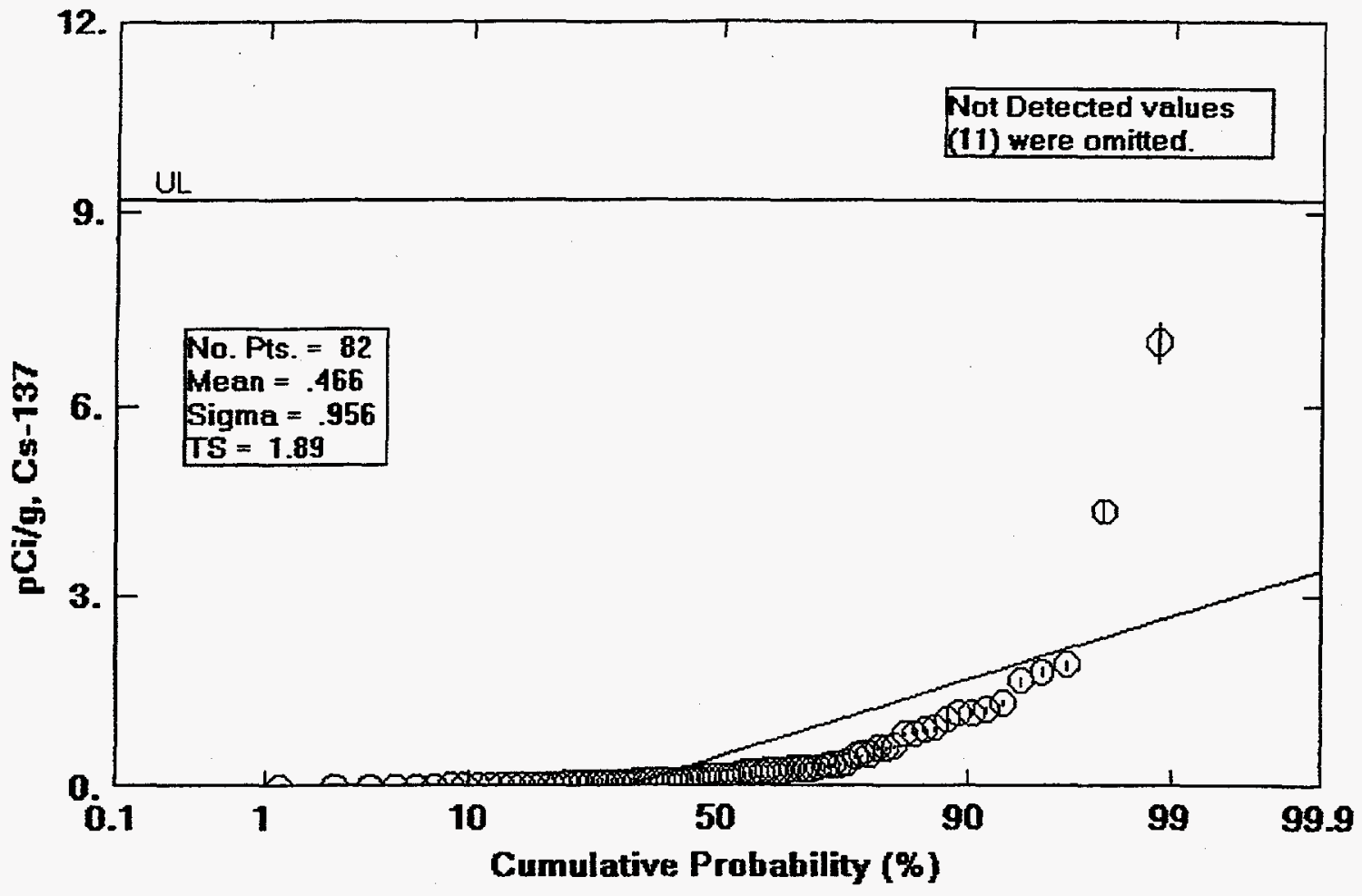

Figure 5-5. Probability Distribution of Cs-137 Activity in Soil Samples 4654 Soil Areas

Table 5-9. 4654 Soil Radioactivity Data -1997

\begin{tabular}{|c|c|c|c|c|c|c|c|c|c|c|c|c|}
\hline & \multicolumn{12}{|c|}{ Activity (pCi/g)a } \\
\hline & H-3 & Be-7 & $\mathbf{K}-40$ & Sr-90 & Cs-137 & T1-208 & $\mathrm{Pb}-210$ & $\mathrm{~Pb}-212$ & Bi-212 & $\mathrm{Pb}-214$ & Bi-214 & Ra-224 \\
\hline $\begin{array}{l}\text { Allowable } \\
\text { Soil Limit }\end{array}$ & 31,900 & natural & 27.6 & 36.0 & 9.2 & chain & chain & chain & chain & chain & chain & chain \\
\hline Maximum & $\mathrm{NM}$ & $\mathrm{ND}$ & 21.66 & NM & 6.99 & 0.54 & 1.28 & 1.77 & 2.22 & 1.37 & 1.22 & 1.74 \\
\hline Mean & NM & ND & 19.78 & NM & 0.47 & 0.37 & 0.84 & 1.24 & 0.97 & 0.8 & 0.76 & 1.22 \\
\hline Minimum & NM & ND & 17.10 & NM & 0.01 & 0.23 & 0.49 & 0.79 & 0.52 & 0.37 & 0.35 & 0.69 \\
\hline \multirow[t]{3}{*}{ Number of } & $\mathrm{NM}$ & $93(93)$ & $93(0)$ & $\mathrm{NM}$ & $93(11)$ & $93(0)$ & $93(34)$ & $93(0)$ & $93(45)$ & $93(0)$ & $93(0)$ & $93(1)$ \\
\hline & \multicolumn{12}{|c|}{ Activity (pCi/g) } \\
\hline & $\mathrm{Ra}-226$ & Ac-228 & Th-227 & Th-228 & Th-230 & Th-232 & Th-234 & U-234 & U-235 & $\mathrm{U}-238$ & Pu-238 & Pu-239 \\
\hline $\begin{array}{l}\text { Allowable } \\
\text { Soil Limit }\end{array}$ & $\begin{array}{l}5 \text { and } \\
15 \\
\end{array}$ & chain & chain & chain & chain & $\begin{array}{l}5 \text { and } \\
15 \\
\end{array}$ & chain & 30.0 & 30.0 & 35.0 & 37.2 & 33.9 \\
\hline Maximum & 1.63 & 1.37 & ND & ND & ND & ND & 1.74 & ND & 0.08 & 2.88 & $\mathrm{NM}$ & NM \\
\hline Mean & 0.81 & 1.03 & ND & ND & ND & ND & 0.77 & ND & 0.04 & 1.92 & $\mathrm{NM}$ & $\mathrm{NM}$ \\
\hline Minimum & 0.30 & 0.66 & $\mathrm{ND}$ & ND & ND & $\mathrm{ND}$ & 0.24 & $\mathrm{ND}$ & 0.01 & 1.40 & $\mathrm{NM}$ & $\mathrm{NM}$ \\
\hline $\begin{array}{l}\text { Number of } \\
\text { Analyses } b\end{array}$ & $93(3)$ & $93(0)$ & $93(93)$ & $93(93)$ & $93(93)$ & $93(93)$ & $93(0)$ & $93(93)$ & $93(0)$ & $93(80)$ & $\mathrm{NM}$ & $\mathrm{NM}$ \\
\hline
\end{tabular}

aNM $=$ Not Measured ND $=$ Not Detected

bNumbers in parentheses represent the number of analyses reported as less than the detectable limit 


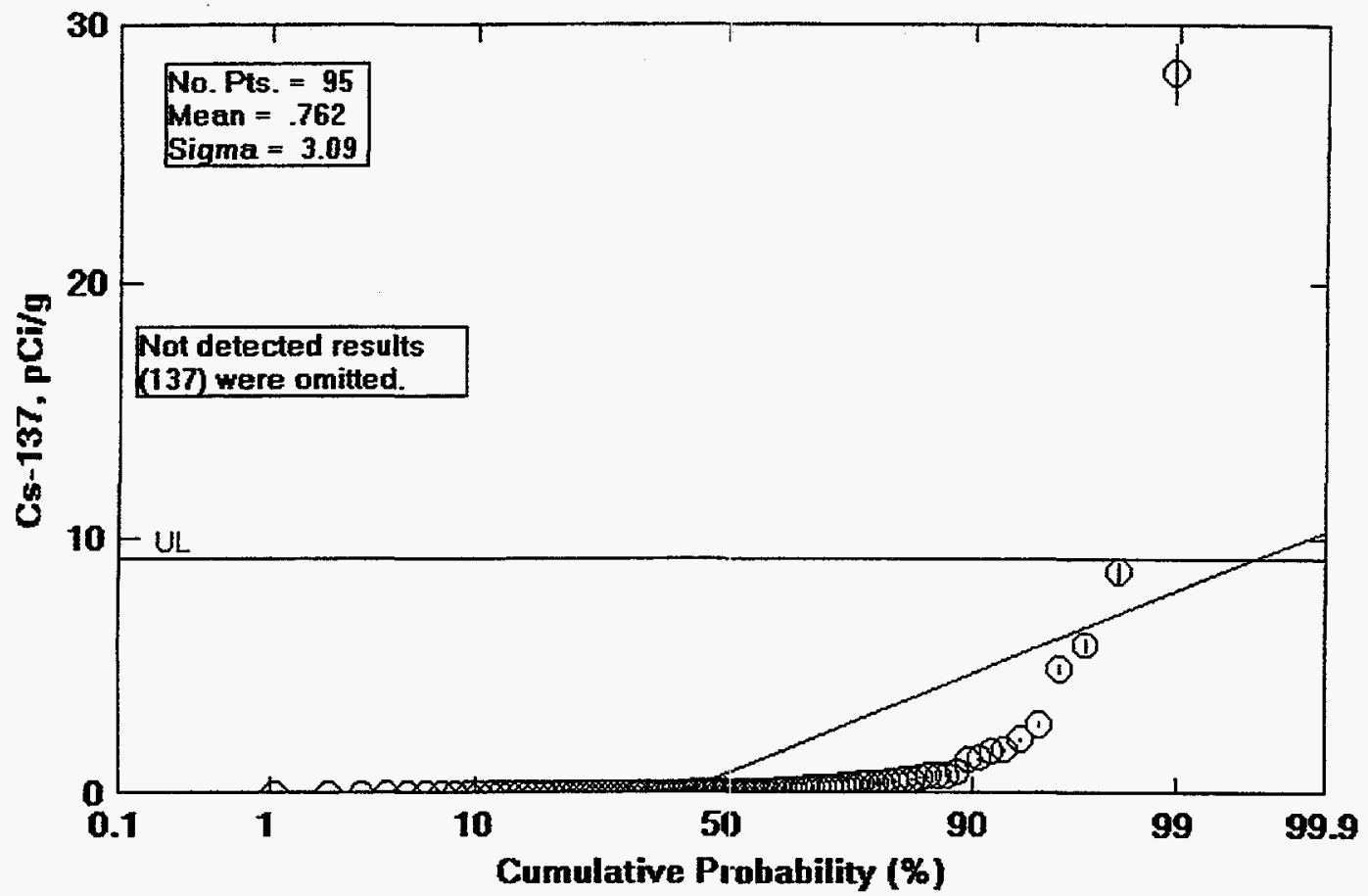

Figure 5-6. Probability distribution of Cs-137 activity in soil samples from the Hot Laboratory Soil Areas

Table 5-10. Hot Laboratory Soil Radioactivity Data -1997

\begin{tabular}{|c|c|c|c|c|c|c|c|c|c|c|c|c|}
\hline & \multicolumn{12}{|c|}{ Activity $(\mathrm{pCi} / \mathrm{g})^{\mathrm{a}}$} \\
\hline & H-3 & $\mathrm{Be}-7$ & $\mathrm{~K}-40$ & Sr-90 & Cs-137 & T1-208 & Pb-210 & $\mathbf{P b}-212$ & Bi-212 & Pb-214 & Bi-214 & Ra-224 \\
\hline $\begin{array}{l}\text { Allowable } \\
\text { Soil Limit }\end{array}$ & 31,900 & natural & 27.6 & 36.0 & 9.2 & chain & chain & chain & chain & chain & chain & chain \\
\hline Maximum & NM & 0.36 & 28.19 & $\mathrm{NM}$ & 28.13 & 0.54 & 1.28 & 1.52 & 22.83 & 1.05 & 1.10 & 1.79 \\
\hline Mean & $\mathrm{NM}$ & 0.18 & 15.71 & NM & 0.76 & 0.36 & 0.77 & 1.04 & 1.36 & 0.66 & 0.64 & 1.10 \\
\hline Minimum & NM & 0.08 & 11.66 & NM & 0.01 & 0.25 & 0.30 & 0.71 & 0.56 & 0.39 & 0.40 & 0.54 \\
\hline \multirow[t]{3}{*}{$\begin{array}{l}\text { Number of } \\
\text { Analyses } \mathbf{b}\end{array}$} & NM & $\begin{array}{c}232 \\
(226) \\
\end{array}$ & $232(1)$ & NM & $\begin{array}{r}232 \\
(137) \\
\end{array}$ & $232(0)$ & $\begin{array}{r}232 \\
(79) \\
\end{array}$ & $232(0)$ & $\begin{array}{r}232 \\
(133) \\
\end{array}$ & $232(0)$ & $232(1)$ & $232(2)$ \\
\hline & \multicolumn{12}{|c|}{ Activity (pCi/g) } \\
\hline & Ra-226 & Ac-228 & Th-227 & Th-228 & Th-230 & Th-232 & Th-234 & U-234 & U-235 & U-238 & Pu-238 & Pu-239 \\
\hline $\begin{array}{l}\text { Allowable } \\
\text { Soil Limit }\end{array}$ & $\begin{array}{l}5 \text { and } \\
15\end{array}$ & chain & chain & chain & chain & $\begin{array}{l}5 \text { and } \\
15 \\
\end{array}$ & chain & 30.0 & 30.0 & 35.0 & 37.2 & 33.9 \\
\hline Maximum & 2.05 & 9.20 & 0.24 & 26.65 & 4.56 & 11.19 & 1.25 & $\mathrm{ND}$ & 0.12 & 3.16 & NM & NM \\
\hline Mean & 1.37 & 1.02 & 0.13 & 10.52 & 3.58 & 11.19 & 0.68 & $\mathrm{ND}$ & 0.08 & 2.19 & $\mathrm{NM}$ & $\mathrm{NM}$ \\
\hline Minimum & 0.72 & 0.70 & 0.06 & 3.01 & 3.02 & 11.19 & 0.29 & $\mathrm{ND}$ & 0.04 & 0.50 & NM & NM \\
\hline $\begin{array}{l}\text { Number of } \\
\text { Analyses } \mathbf{b}\end{array}$ & $232(7)$ & $232(0)$ & $\begin{array}{r}232 \\
(218) \\
\end{array}$ & $\begin{array}{r}232 \\
(228) \\
\end{array}$ & $\begin{array}{r}232 \\
(229) \\
\end{array}$ & $\begin{array}{r}232 \\
(231) \\
\end{array}$ & $232(2)$ & $\begin{array}{r}232 \\
(232) \\
\end{array}$ & $232(1)$ & $\begin{array}{r}232 \\
(206) \\
\end{array}$ & NM & NM \\
\hline
\end{tabular}

aNM $=$ Not Measured ND $=$ Not Detected

$b_{N}$ umbers in parentheses represent the number of analyses reported as less than the detectable limit 


\subsubsection{Vegetation}

Two vegetation samples were collected in 1997. The first, collected at the Hot Lab on 7/29/97, contained $\mathrm{Cs}-137$ at $0.096 \mathrm{pCi} / \mathrm{g}$, which is consistent with nuclear weapons testing fallout values. The second sample was collected at the $17^{\text {th }}$ Street drainage area and contained no unnatural activity.

\subsubsection{Wildlife}

No animal samples were collected in 1997.

\subsubsection{Ambient Radiation}

During the later years of the nuclear programs at Atomics International and Rocketdyne, from 1974 through 1989, the ambient radiation monitoring program used rather complicated bulb-type dosimeters $\left(\mathrm{CaF}_{2}: \mathrm{Mn}\right)$. This was justified by the amount of nuclear materials handled in the operations at SSFL and De Soto, and by the low levels of radiation in the environment. At the termination of all nuclear work in 1989, such a program was no longer needed, and efforts were directed toward simplifying the program. This was done initially by using the same dosimeters $(\mathrm{LiF})$ that were well established in use for personnel monitoring in radiation work. While these dosimeters are well suited to measuring exposures in the range of interest for compliance with occupational radiation regulations (doses "above background"), they are somewhat insensitive for environmental measurements since the resolution in terms of dose uses increments of 10 mrem per quarter. Using these dosimeters demonstrated that environmental exposures did not reach regulatory limits, but provided limited information on the actual exposure rates present around the facilities and in the neighboring environment.

In addition to the LiF TLDs discussed above, Rocketdyne began deploying, in the last quarter of 1995, environmental TLDs that utilize an aluminum oxide ("sapphire") chip. These TLDs are capable of determining doses in increments of $0.1 \mathrm{mrem}$ (compared to $10 \mathrm{mrem}$ for the LiF-based badges previously used). In addition, the aluminum oxide badge reporting is much more detailed, providing both gross and corrected readings for the locations. Proper use of the control badges supplied with these dosimeters allows elimination of the natural and transportation exposure that occurs before, during, and after the deployment of the environmental dosimeters to measure the ambient radiation. This permits accurate determination of the net exposure received while the environmental TLDs are in the field, exposed to the ambient radiation. In various intercomparisons, aluminum-oxide-based dosimeters have been shown to be among the most accurate dosimeters available in measuring environmental exposure rates.

The State $\mathrm{RHB}$ provides packages containing calcium sulfate $\left(\mathrm{CaSO}_{4}\right)$ dosimeters for independent monitoring of radiation levels at SSFL and in the surrounding area. These dosimeters are placed at specific locations along with the Rocketdyne TLDs. The State dosimeters are returned to the Radiologic Health Branch for evaluation. Data for these TLDs, which were placed at various Rocketdyne dosimeter locations both onsite and offsite, are also shown in Table 5-11 for 1997. 
Except for dosimeter locations SS-12, and -13, Table 5-11 shows that radiation exposures and equivalent annual exposure rates monitored onsite are nearly identical to levels monitored at the offsite locations. These data reflect natural background radiation from cosmic radiation, radionuclides in the soil, and radon and thoron in the atmosphere. Radiation doses measured at locations SS-12, and -13 , are slightly higher, and are reflective of normal operations at the RMHF, which involve handling and shipment of radioactive material.

The natural background radiation level as measured by the offsite dosimeters is approximately $86 \mathrm{mrem} / \mathrm{yr}$. At the SSFL the local background ranges from 86 to $109 \mathrm{mrem} / \mathrm{yr}$, based on the data from dosimeters SS-3, $-4,-6,-7,-8,-11,-14$ and EMB-1 and EMB-2 as shown in Table 5-11. At De Soto, the local background is approximately $91 \mathrm{mrem} / \mathrm{yr}$. The small variability observed in these values is attributed to differences in elevation and geologic conditions at the various sites. The altitude range for the dosimeter locations is from approximately $260 \mathrm{~m}(850 \mathrm{ft}) \mathrm{ASL}$ at the De Soto facility and the offsite locations to a maximum of approximately $580 \mathrm{~m}(1,900 \mathrm{ft})$ ASL at SSFL.

Analysis of the results demonstrates that compliance was achieved with the annual limits of the NRC, the State of California Department of Health Services, and the U.S. Department of Energy the limit being $100 \mathrm{mrem} / \mathrm{yr}$ for total dose, above natural background, to the maximally exposed individual.

Starting in the second half of 1997, the control dosimeters at SSFL are being stored in a special low-background shield that should eliminate the previous difficulties in comparing the Rocketdyne measurements with the DHS/RHB. 
Table 5-11. DeSoto and SSFL Ambient Radiation Dosimetry Data-1997

\begin{tabular}{|c|c|c|c|c|c|c|c|c|}
\hline $199^{\prime}$ & & $\mathrm{RDQ}$ & rterly & posur & arem) & \begin{tabular}{|l|} 
Annual \\
Exposure
\end{tabular} & $\begin{array}{l}\text { Annual } \\
\text { Expo } \\
\text { Rate }\end{array}$ & $\begin{array}{l}\text { verage } \\
\text { ure } \\
\text { (R/h) }\end{array}$ \\
\hline TLD-L & ations & Q-1 & Q-2 & Q-3 & $Q-4$ & (mrem) & Rocketdyne & State DHS \\
\hline DeSoto & $\begin{array}{l}\text { DS-2 } \\
\text { DS_6 } \\
\text { DS-8 } \\
\text { DS-9 }\end{array}$ & $\begin{array}{c}20.2 \\
33 \\
28.5 \\
21.1 \\
\end{array}$ & $\begin{array}{l}23.0 \\
22.3 \\
22.7 \\
28.6 \\
\end{array}$ & $\begin{array}{l}16.3 \\
22.6 \\
20.7 \\
24.8 \\
\end{array}$ & $\begin{array}{l}21.3 \\
19.1 \\
19.1 \\
25.5 \\
\end{array}$ & $\begin{array}{c}80.8 \\
97.0 \\
91.0 \\
100.0 \\
\end{array}$ & $\begin{array}{c}9.2 \\
11.0 \\
10.3 \\
11.4 \\
\end{array}$ & $\begin{array}{l}- \\
- \\
-\end{array}$ \\
\hline Mean V & lues & 25.7 & 24.2 & 21.1 & 21.3 & 92.2 & 10.5 & \\
\hline SSFL & \begin{tabular}{|l|} 
SS-3 \\
SS-4 \\
SS-6 \\
SS-7 \\
SS-8 \\
SS-9 \\
SS-11 \\
SS-12 \\
SS-13 \\
SS-14 \\
EMB-1 \\
EMB-2 \\
\end{tabular} & $\begin{array}{l}28.8 \\
28.8 \\
27.8 \\
27.8 \\
38.9 \\
27.2 \\
36.4 \\
41.7 \\
40.5 \\
35.7 \\
31.9 \\
31.9 \\
\end{array}$ & $\begin{array}{l}28.8 \\
26.9 \\
27.1 \\
27.9 \\
29.4 \\
32.0 \\
28.4 \\
34.7 \\
40.3 \\
31.8 \\
31.9 \\
26.9 \\
\end{array}$ & $\begin{array}{l}18.3 \\
28.9 \\
26.9 \\
24.9 \\
28.1 \\
29.4 \\
26.0 \\
27.6 \\
30.6 \\
31.3 \\
31.9 \\
21.9 \\
\end{array}$ & $\begin{array}{l}26.0 \\
24.3 \\
23.8 \\
23.8 \\
24.6 \\
26.9 \\
25.5 \\
28.6 \\
32.1 \\
26.4 \\
31.9 \\
26.9 \\
\end{array}$ & $\begin{array}{l}101.9 \\
108.9 \\
105.6 \\
104.4 \\
121.0 \\
115.5 \\
116.3 \\
132.6 \\
143.5 \\
125.2 \\
127.6 \\
107.6 \\
\end{array}$ & $\begin{array}{l}11.6 \\
12.4 \\
12.0 \\
11.9 \\
13.7 \\
13.1 \\
13.2 \\
15.1 \\
16.3 \\
14.2 \\
14.5 \\
12.2 \\
\end{array}$ & $\begin{array}{l}11.1 \\
12.7 \\
12.4 \\
11.6 \\
13.0 \\
13.6 \\
12.9 \\
16.2 \\
14.4 \\
14.0 \\
12.9 \\
12.7 \\
\end{array}$ \\
\hline Mean V & hes & 33.1 & 30.5 & 27.2 & 26.7 & 117.5 & 13.3 & 13.1 \\
\hline Offsite & $\begin{array}{l}\text { OS-1 } \\
\text { OS-5 } \\
\text { BKG-11 } \\
\text { BKG-12 } \\
\text { BKG-13 } \\
\text { BKG-15 } \\
\text { BKG-16 } \\
\text { BKG-18 } \\
\text { BKG-19 } \\
\text { BKG-20 } \\
\text { BKG-21 } \\
\text { BKG-22 } \\
\end{array}$ & $\begin{array}{c}27.3 \\
24.4 \\
21.8 \\
26.9 \\
20.5 \\
30.5 \\
18.2 \\
27.3 \\
26.9 \\
30.1 \\
26 \\
21 \\
\end{array}$ & $\begin{array}{l}22.9 \\
20.3 \\
26.2 \\
31.6 \\
23.1 \\
22.4 \\
18.2 \\
31.3 \\
23.9 \\
19.2 \\
22.6 \\
29.7 \\
\end{array}$ & $\begin{array}{l}22.3 \\
18.1 \\
19.3 \\
18.3 \\
16.4 \\
20.8 \\
21.1 \\
16.0 \\
21.4 \\
22.1 \\
18.9 \\
17.8 \\
\end{array}$ & $\begin{array}{l}21.8 \\
13.3 \\
17.5 \\
19.9 \\
15.2 \\
16.2 \\
15.2 \\
18.8 \\
16.3 \\
17.6 \\
25.2 \\
13.6 \\
\end{array}$ & $\begin{array}{l}94.2 \\
76.1 \\
84.8 \\
96.7 \\
75.2 \\
89.9 \\
72.6 \\
93.4 \\
88.5 \\
89.0 \\
92.7 \\
82.1 \\
\end{array}$ & $\begin{array}{c}10.7 \\
8.6 \\
9.6 \\
11.0 \\
8.5 \\
10.2 \\
8.2 \\
10.6 \\
10.0 \\
10.1 \\
10.5 \\
9.3 \\
\end{array}$ & $\begin{array}{c}10.4 \\
-- \\
-- \\
-- \\
-- \\
-- \\
-- \\
-- \\
- \\
- \\
\end{array}$ \\
\hline Mean V & lues & 25.1 & 24.3 & 19.4 & 17.5 & 86.3 & 9.8 & - \\
\hline
\end{tabular}




\subsection{ESTIMATION OF PUBLIC RADIATION DOSE}

Because so little radioactive material is released from the Rocketdyne facilities, and the radiation exposure is so small compared to natural background, it is not possible to directly measure radiation dose to the public. Hypothetical doses were estimated based on direct measurements at the facilities, extrapolated to occupied areas offsite. The external dose calculations assume that differences in observed TLD readings represent true differences in local exposure. These TLD measurements, which are assumed to represent point sources at the Hot Lab and RMHF, are extrapolated to the boundary and nearest residence using an inverse square distance relation, and accounting for air attenuation of the radiation. The external exposures, above background, are then obtained by subtracting from these extrapolated values an average background exposure obtained from offsite measurements.

\subsubsection{Individual Dose}

For 1997, the estimated dose at the property line boundary nearest the RMHF was calculated to be $48 \mathrm{mrem} / \mathrm{yr}$ above local background (an average exposure rate of $5.5 \mu \mathrm{R} / \mathrm{hr}$ above background). Similarly, for the nearest residence, the annual dose estimate for 1997 was calculated to be $0.00017 \mathrm{mrem}$. For these calculations, the external dose estimate at the boundary was obtained by extrapolation of data from three environmental monitoring TLDs (SS12, -13 , and -14 shown earlier in Table 5-11) located at the RMHF. For the nearest residence dose, data from 14 separate facility TLDs (not listed in Table 5-11) was used for extrapolation. The average annual background used in both calculations was obtained from the fourteen offsite dosimeters and was $86 \mathrm{mrem}$. Boundary dose estimates assume $100 \%$ occupancy, whereas the actual presence of persons at the boundary is rare or nonexistent. The estimated doses are far below the applicable limits of DOE and the State of California.

The effective dose equivalent for any member of the public, for all pathways (combining internal and external dose), shall not exceed $100 \mathrm{mrem} / \mathrm{yr}$ (above background) for DOE facilities or State of California licensed facilities. Except for the nearest boundary line exposure for the RMHF, the estimated offsite doses are extremely low compared to the maximum permissible exposures recommended for the general population in the vicinity of DOE facilities. As discussed above, the RMHF boundary to the north of the facility received an estimated average "property line" exposure of approximately $48 \mathrm{mrem} / \mathrm{yr}$ above the local background. However, this does not constitute a dose to the general public since it lies within an isolated area without direct public access.

Estimates of the internal dose assume a constant unsheltered exposure throughout the year, adjusted for wind direction frequency, and therefore considerably overestimate the actual annual averaged doses near the site. Estimated internal radiation doses due to atmospheric emission of radioactive materials from De Soto and the SSFL nuclear facilities are calculated by use of the EPA program CAP88-PC, and are several orders of magnitude below the radiation standards and are far below doses from internal exposure resulting from natural radioactivity in air. For the air 
pathway only, for DOE operations, the standard is $10 \mathrm{mrem} / \mathrm{yr}$ for committed effective dose equivalent, as established by EPA.

Public exposure to radiation and radioactivity is shown in Tables 5-12 and Table 5-13. These tables present the estimated exposures in comparison to the regulatory standards and that received due to natural radioactivity in the environment. Dose values in the tables represent both internal and external exposures.

\section{Table 5-12. Public Exposure to Radiation and Radioactivity from DOE Operations at SSFL - 1997}

\section{Radioactive Materials Handling Facility (RMHF) Hot Lab and 4024 Hot Lab Satellite Department of Energy (DOE, Exempt from Licensing)}

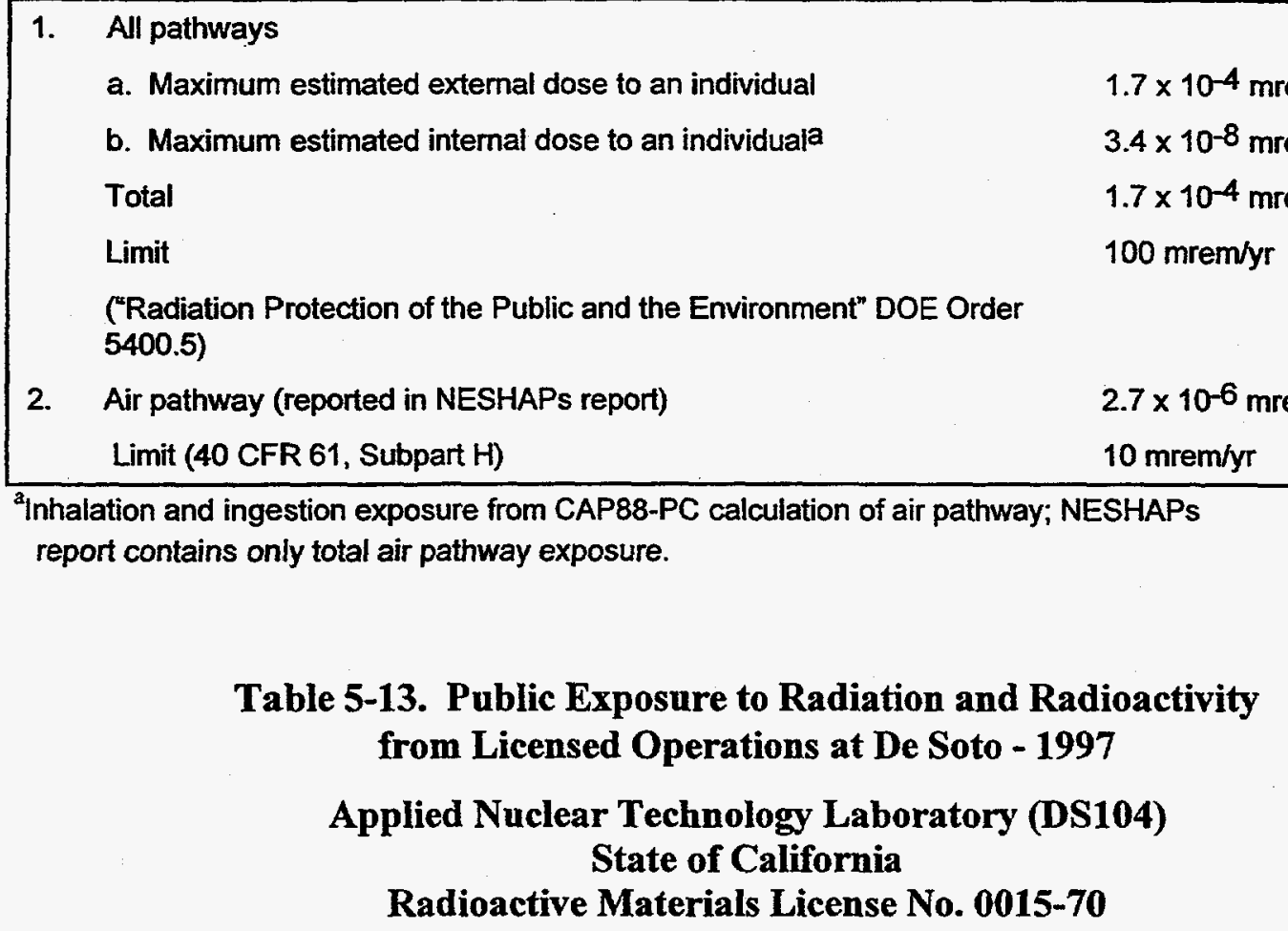

2. Air pathway (reported in NESHAPs report)

100 mrem/yr

$10 \mathrm{mrem} / \mathrm{yr}$

anhalation and ingestion exposure from CAP88-PC calculation of air pathway; NESHAPs report contains only total air pathway exposure.

Table 5-13. Public Exposure to Radiation and Radioactivity from Licensed Operations at De Soto - 1997

Applied Nuclear Technology Laboratory (DS104) State of California

Radioactive Materials License No. 0015-70

$1.7 \times 10^{-4} \mathrm{mrem} / \mathrm{yr}$

$3.4 \times 10^{-8} \mathrm{mrem} / \mathrm{yr}$

$1.7 \times 10^{-4} \mathrm{mrem} / \mathrm{yr}$

\begin{tabular}{|c|c|c|}
\hline \multirow[t]{2}{*}{1.} & Direct radiation at boundary & 0.054 mrem $/ y r$ \\
\hline & Limits (CCR 17 Section 30253) & $100 \mathrm{mrem}$ in $1 \mathrm{yr}$ \\
\hline \multirow[t]{2}{*}{2.} & Airborne (non-natural radioactivity) effiuent at boundarya & 2.4E-21 $\mu \mathrm{Ci} / \mathrm{mL}$ \\
\hline & Limit (CCR 17 Section 30253) & $2 \mathrm{E}-14 \mu \mathrm{Ci} / \mathrm{mL}$ \\
\hline
\end{tabular}

a Use of the EPA computer program, COMPLY, to determine the air pathway dose from the measured radionuclide concentrations for the ventilation exhaust from the Applied Nuclear Technology Laboratories at De Soto showed this facility to be in compliance with 40 CFR 61, Subpart I, at Level 1, the simplest, most conservative screening level. 


\subsubsection{Population Dose}

The general population (person-rem) dose estimates were calculated using CAP88-PC code. This code uses release rate, wind speed, wind direction and frequency, stability fractions, and stack height parameters as input data. Population dose estimates are $7.6 \times 10^{-3}$ person-rem for the SSFL site and $3.1 \times 10^{-5}$ person-rem for the De Soto site. The collective effective dose equivalent estimated for potential area sources in 1997 is $6.8 \times 10^{-3}$ person-rem, included in the SSFL total. Inhalation is the only potential exposure pathway likely to exist. Figure 5-7 shows the arrangement of the census tract boundaries from the 1990 census. Figures 5-8 through 5-11 show local population distribution estimates that were determined from the 1990 Federal census by Urban Decision Systems, Inc., and modified by direct observation of nearby residential areas around the SSFL site, and the occupational population at SSFL.

In spite of the large number of people in the surrounding population, the population dose estimated for Rocketdyne operations is extremely small. For comparison, the dose received by the same population from naturally occurring radiation is approximately 3 million person-rem, approximately one half billion times greater than that estimated for SSFL operations.

To account for population increases, analytical results using the 1990 census data were multiplied by 1.03 for the DeSoto facility and 1.10 for Area IV of the SSFL. This factor was based on population increases in Los Angeles and Ventura counties since 1990 as reported by the US Census Bureau. 


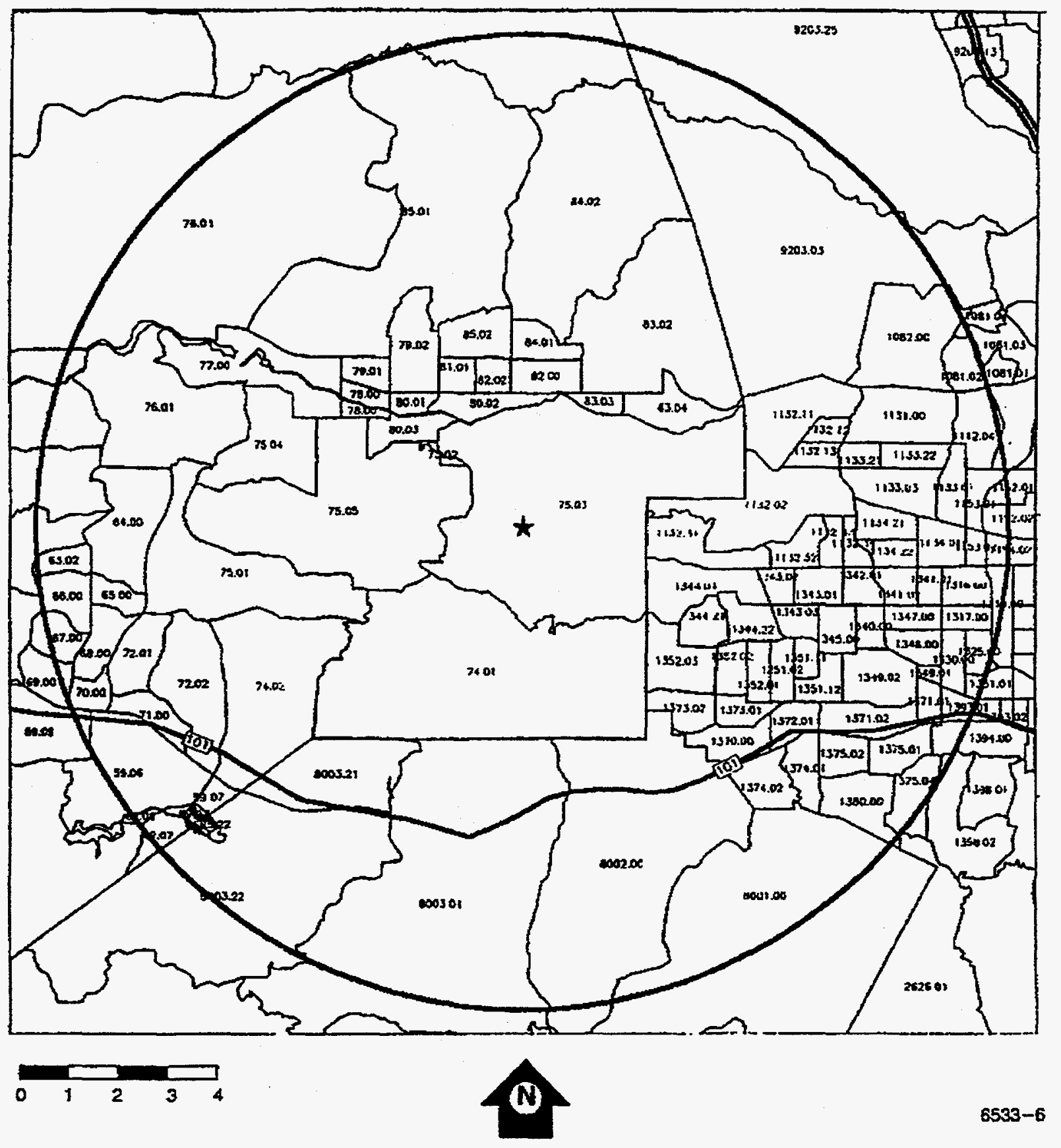

Figure 5-7. Census Tract Boundaries (1990) within 10 miles of SSFL (individual tracts are identified by number) 


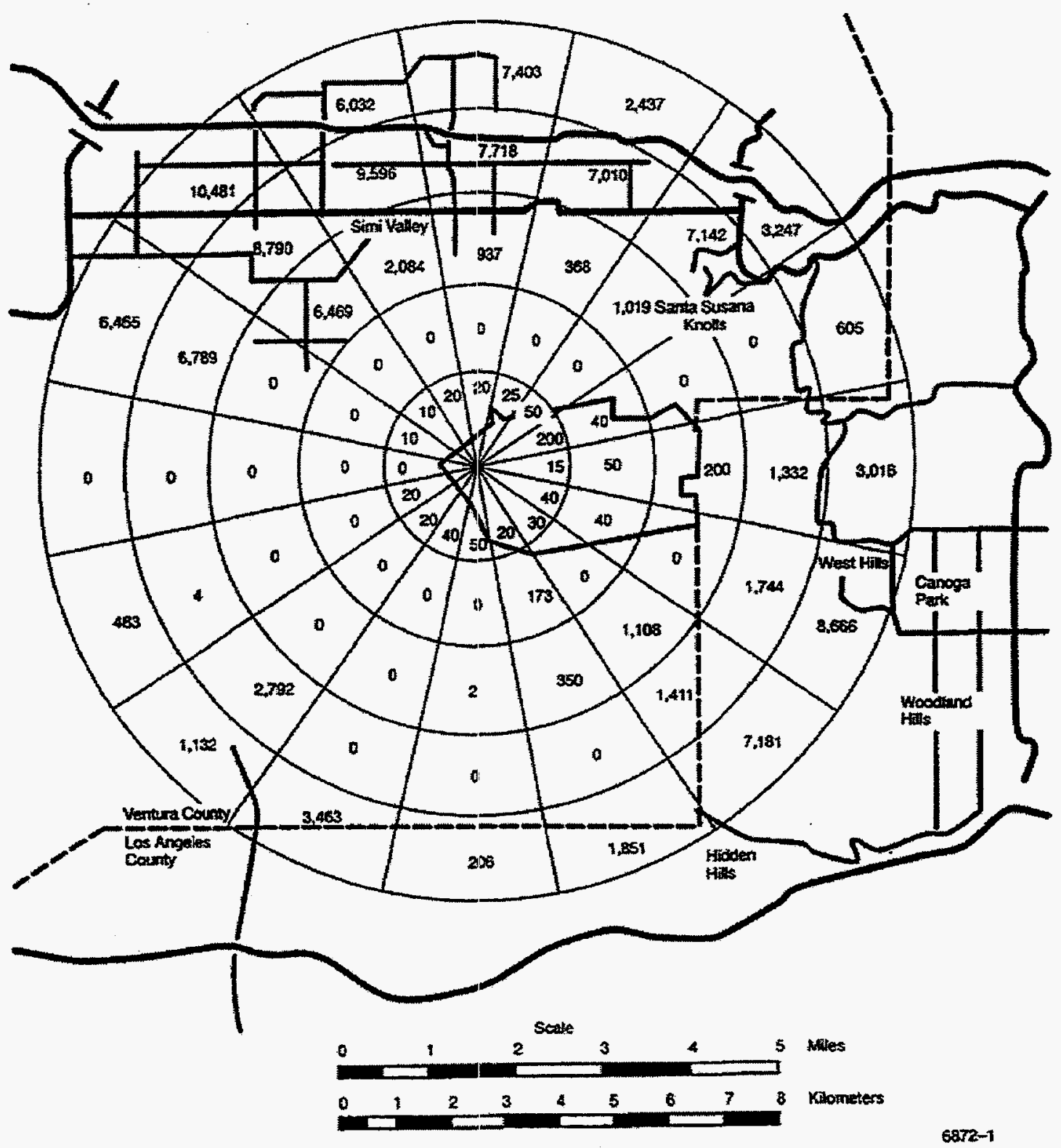

$5857-4$

Figure 5-8. SSFL Site-Centered Demography to $8 \mathrm{~km}$ (1990), Showing Number of Persons Living in Each Grid (daytime employment for SSFL) 


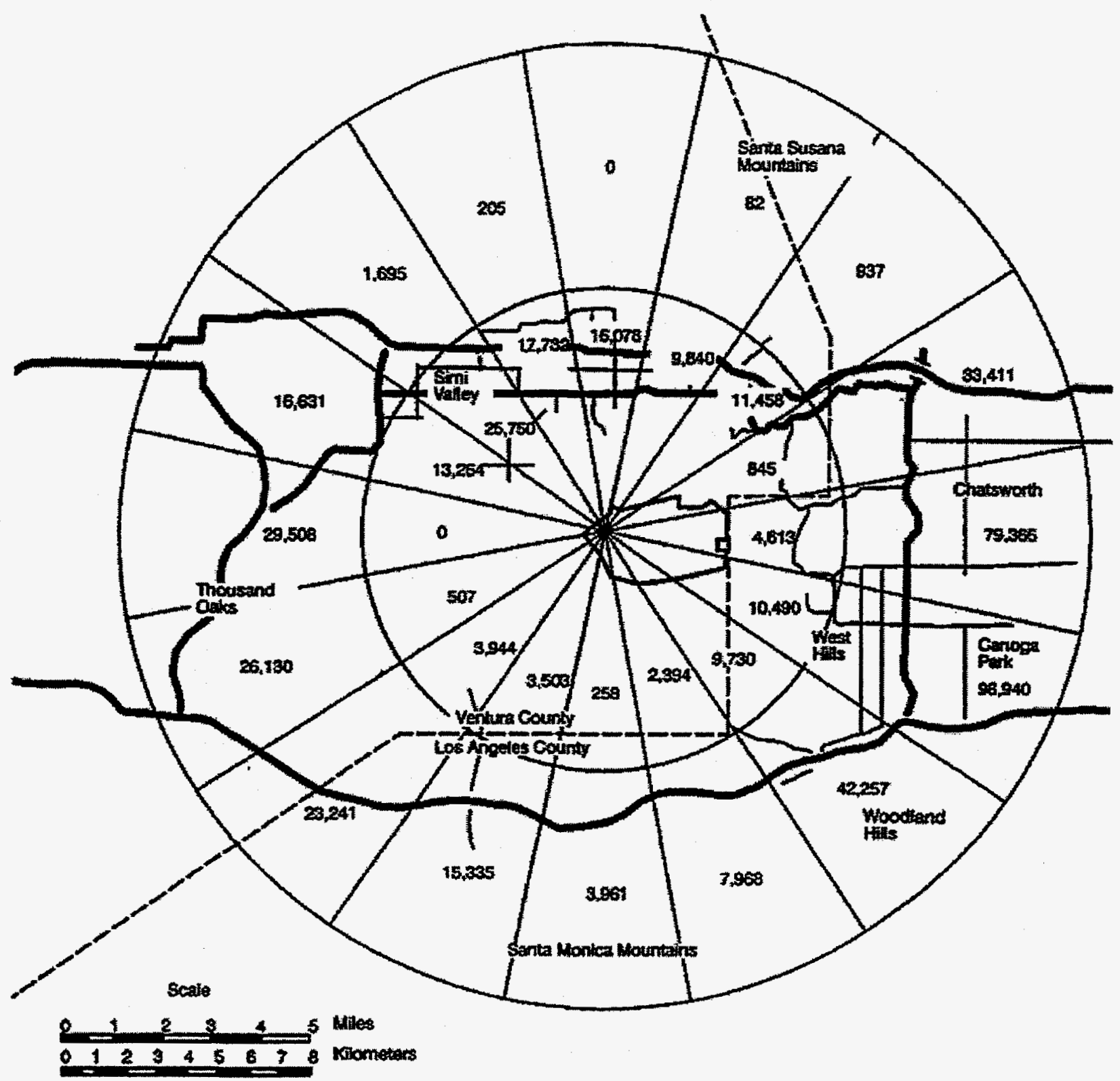

$5857-4$

Figure 5-9. SSFL Site-Centered Demography to $16 \mathrm{~km}$ (1990), Showing Number of Persons Living in Each Grid 


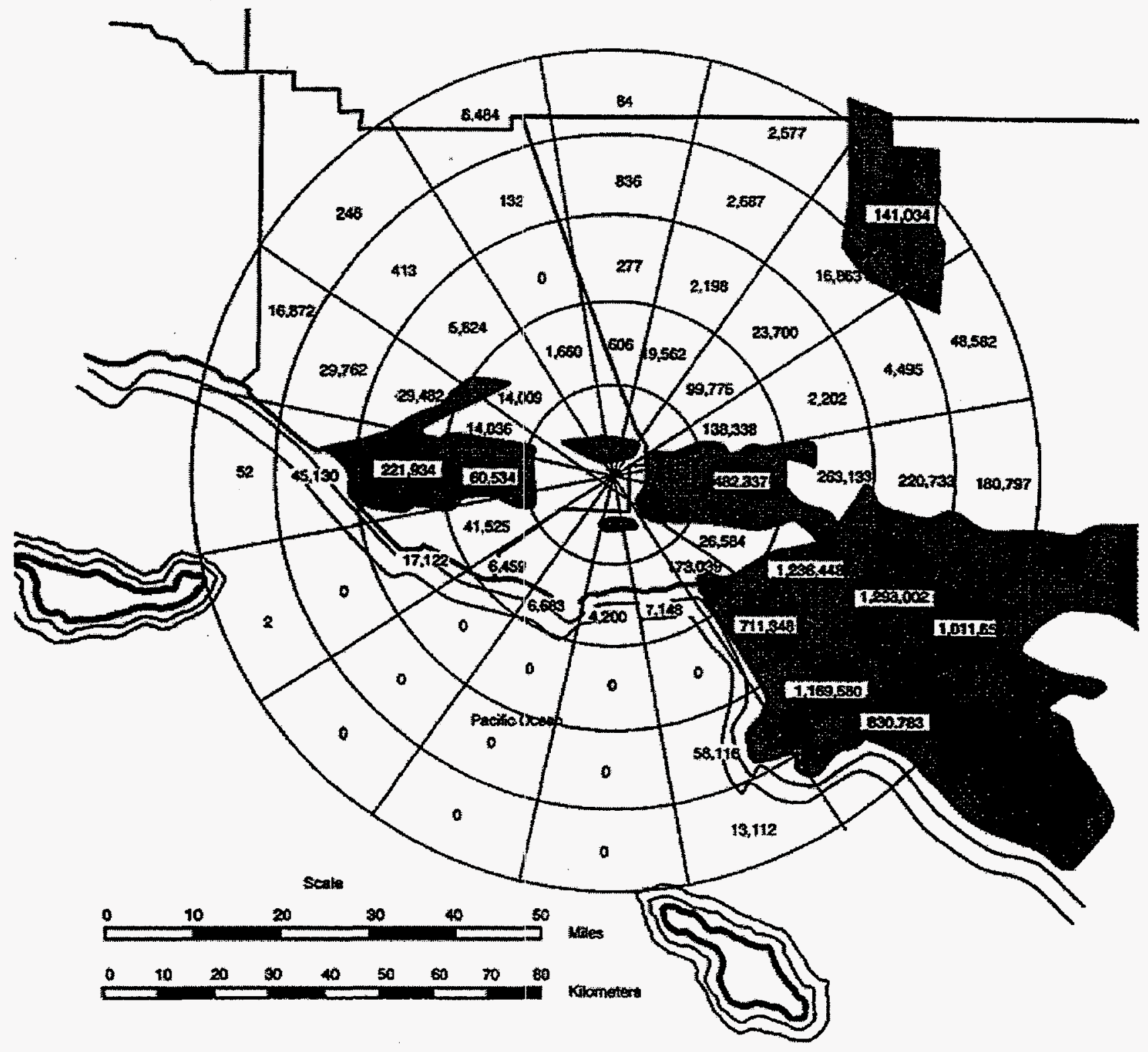

Figure 5-10. SSFL Site-Centered Demography to $80 \mathrm{~km}$ (1990), Showing Number of Persons Living in Each Grid (heavily populated areas are shown by shading) 


\section{ENVIRONMENTAL NON-RADIOLOGICAL MONITORING}

Rocketdyne maintains a comprehensive environmental program to ensure compliance with all applicable regulations, to prevent adverse environmental impact, and to restore the quality of the environment from past operations. Petroleum hydrocarbon contaminated soils resulting from underground storage tanks have been remediated as tanks are removed. The majority of the storage tanks have been removed. The few remaining USTs contain either sodium or radioactive water and are located within concrete vaults and equipped with automatic leak detection systems. As stated previously, these tanks are exempt from the UST regulations.

An extensive site-wide (SSFL) groundwater remediation program has the capacity for removing solvent contamination from approximately one million gallons of groundwater per month at SSFL. The major groundwater contaminant in Area IV is TCE and its degradation products. Two interim groundwater extraction system wells have been installed in Area IV and evaluation of their performance is in progress.

The discharge of surface water at SSFL results from collection of rainfall runoff or is due to the nonutilization of treated groundwater and is regulated by the California Regional Water Quality Control Board through an NPDES permit. The majority of surface water runoff drains to the south and is collected in the water reclamation/pond system. Discharges from this system are subject to effluent limitations and monitoring requirements as specified in the existing NPDES permit. A small portion of the site within Area IV generates rainfall runoff to five northwest boundary runoff channels where monitoring locations (Figure 6-1) have been established and sampling is conducted in accordance with the northwest slope monitoring program. All discharges are periodically monitored for volatile organics, heavy metals, and applicable radionuclides, in addition to other parameters necessary to assess water quality.

All sources of air emissions at SSFL are subject to the provisions of the Clean Air Act as administered through the California Air Resources Board and the Ventura County Air Pollution Control District. The VCAPCD regulates sources of air emissions and issues permits that contain limits on pollutant levels and conditions of operation. 


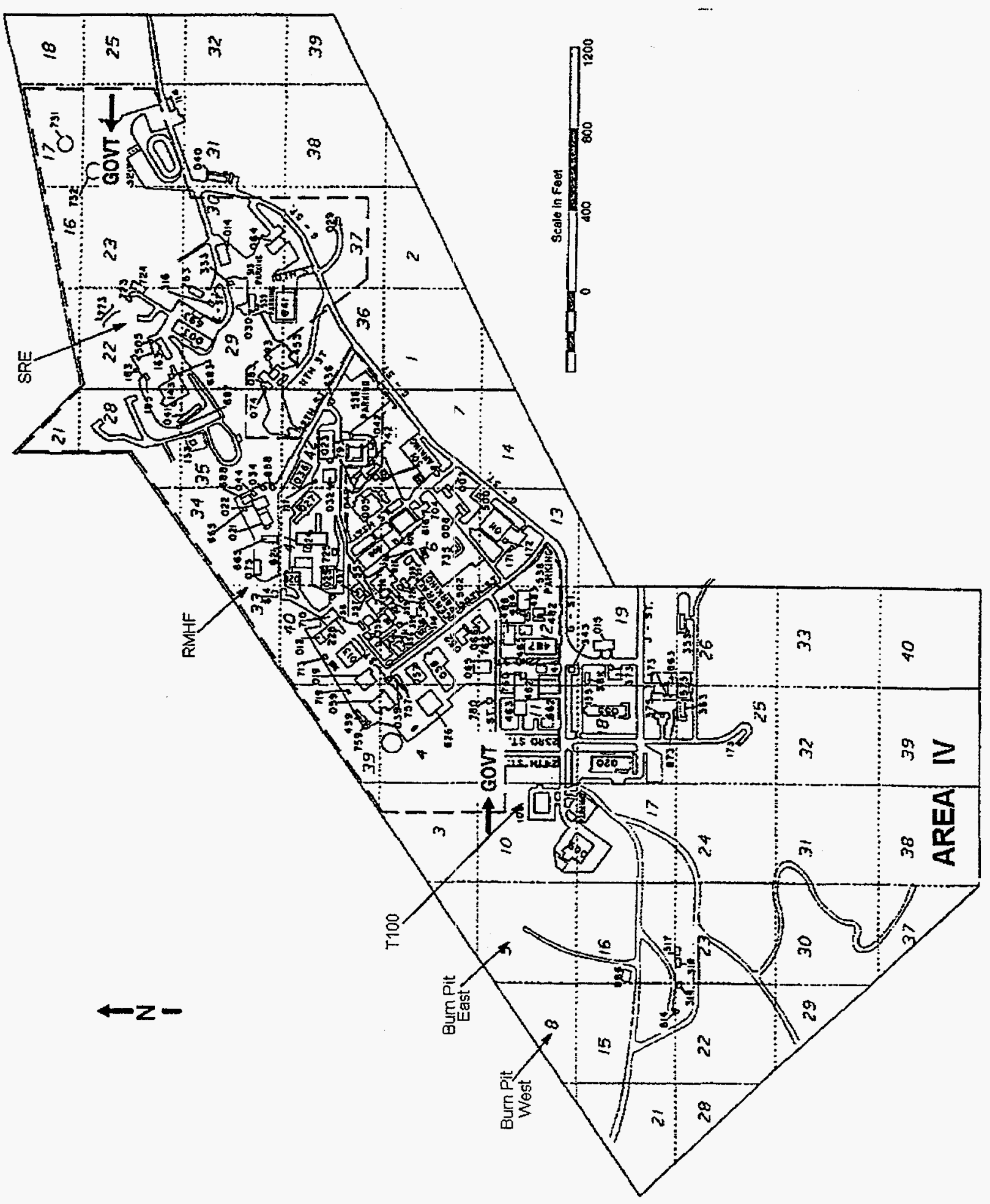

.Figure 6-1. Locations of Surlace Water Runoff Collectors Along Northwest Boundary of SSFL, Area IV 
The overall annual groundwater monitoring program at SSFL addresses collection and analysis of groundwater samples and measurement of the water levels for the 227 Rocketdyne installed wells onsite and offsite and 16 offsite private wells. The locations of these wells within and around DOE areas in Area IV are shown on the map of SSFL in Figure 6-2. Groundwater quality parameters and sampling frequency have been determined based on historical water quality data, location of known or potential sources of groundwater contamination, operational requirements of groundwater extraction and treatment systems and regulatory direction. The groundwater monitoring program includes the following parameters, all analyzed using the appropriate EPA methods: volatile organic constituents, base/neutral and acid extractable organic compounds, petroleum hydrocarbons, and trace metals and common ion constituents.

Radiological analyses are performed on groundwater samples from DOE areas in Area IV and offsite. 


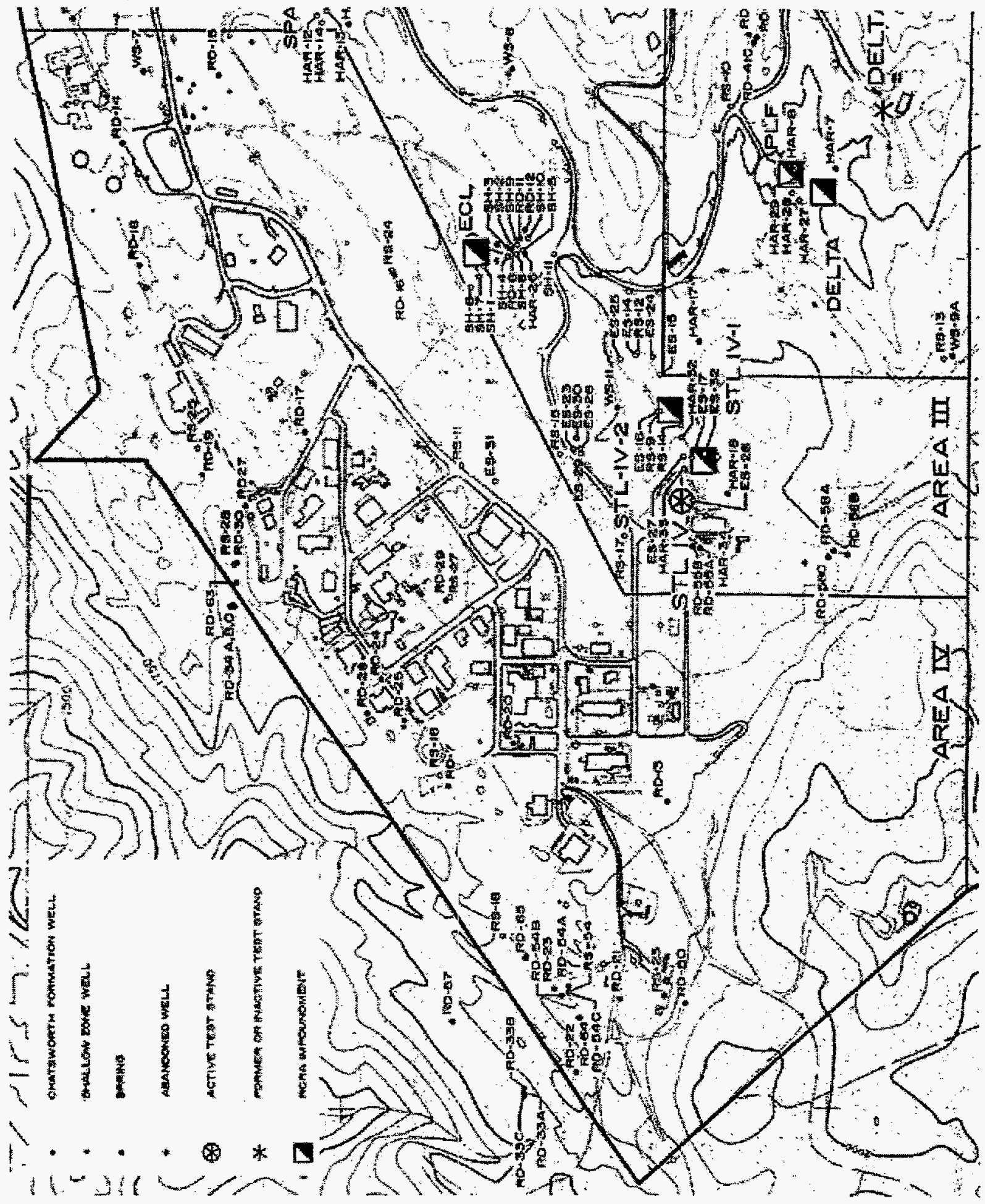

Figure 6-2. Location of Wells Used in Groundwater Management Program environ.doc 


\subsection{SURFACE WATER}

Rocketdyne has filed a Report of Waste Discharge with the California Regional Water Quality Control Board and has been granted a discharge permit pursuant to the National Pollutant Discharge Elimination System and Section 402 of the federal Water Pollution Control Act. The permit to discharge, NPDES No. CA0001309, initially became effective September 27, 1976. The permit was renewed with minor changes effective September 17, 1984 and was revised prior to reissuance on June 29, 1998. The current permit is in effect through May 10, 2003.

The permit allows the discharge of reclaimed wastewater and storm water runoff from water retention ponds into Bell Creek, a tributary to the Los Angeles River, in addition to the discharge of storm water runoff from the northwest slope (Area IV) locations. Discharge along the northwest slope (Outfalls 003 through 007) generally occurs only during and after periods of heavy rainfall. The permit applies the numerical limits for radioactivity in drinking water supplies to drainage through these outfalls. There were no permit exceedances at these outfalls in 1997. Excess reclaimed water is now discharged on a continuous basis through the R-2A outfall location (Outfall 002).

There is no sanitary sewer discharge from SSFL. Domestic sewage is treated, disinfected, and discharged to the retention ponds. Permit conditions are placed on the operation of the two treatment plants. Area IV sewage is piped directly to the Area III Sewage Treatment Plant (STP III).

Of the two retention ponds at SSFL that discharge via the NPDES permit, only one receives influent from Area IV, and is referred to as R-2A Pond. Influent to the ponds includes tertiary treated domestic sewage, cooling water from various testing operations, and storm water runoff. During periods of discharge from the ponds, grab-type samples are collected for analysis by a California State certified testing laboratory. Analyses include chemical constituents such as heavy metals, volatile organics, base/neutral and acid extractable, and general chemistry in addition to specified radionuclides. Toxicity testing is also conducted in the form of acute and chronic toxicity bioassays.

In November 1989, a storm water runoff program was developed and implemented in Area IV for runoff from the northwest portion of the site. Five monitoring locations were selected that include the Radioactive Materials Handling Facility watershed (Outfall 003), Sodium Reactor Experiment watershed (Outfall 004), the Former Sodium Disposal Facility (Outfalls 005 and 006), and behind 4100 (Outfall 007). Runoff monitoring is currently conducted as set forth by the NPDES permit referenced above. Furthermore, all surface water program activities for the SSFL, including Area IV, have been addressed and incorporated into the current NPDES permit. The Storm water Pollution Prevention Plan and the NPDES permits were both prepared in accordance with the current federal and state regulations. 
The permit imposes the contaminant limits for drinking water suppliers, relative to radioactivity, and goes far beyond the requirements of the drinking water supplier regulations in requiring much more frequent sampling and analysis. For Outfalls 001 and 002, during periods of discharge, and whenever rainfall is greater than $0.1 \mathrm{inch}$, no more than one sample per week needs to be obtained. During dry weather flow, minimum sampling frequency for these two outfalls shall be once per month. For discharges from Outfalls 003, 004, 005, 006, and 007, no more than one sample per week need be obtained.

\subsection{AIR}

Air was monitored during and after asbestos removal activities to verify compliance with exposure limits.

\subsection{GROUNDWATER}

A groundwater monitoring program has been in place at the SSFL site since 1984. Currently, the monitoring system includes 243 onsite and offsite wells. There are 7 offsite wells, installed by Rocketdyne, near the northwest boundary of Area IV that had been offsite on land that was acquired by Boeing in 1997. The groundwater at SSFL exists in two geologic units. One is the loose and unconsolidated alluvium on bedrock, which is termed the Shallow Zone. The other is the bedrock itself, termed the Chatsworth formation. Groundwater in the shallow zone is very seasonal. At many sites the Shallow Zone is dry in the summer. Within Area IV, the Shallow Zone has $9 \mathrm{DOE}$ installed wells. The Chatsworth formation, the indurated and fractured sandstone constitutes the dominant aquifer underlying the facility. It has $36 \mathrm{DOE}$ installed wells in and around Area IV.

Routine quarterly chemical and radiological monitoring of the wells is conducted according to the monitoring plan submitted to the lead agency for the groundwater program. Quarterly reports are submitted to the regulatory agencies at the end of the first three quarters. An annual report is submitted after the monitoring for the fourth quarter is completed.

The Shallow Zone is an unconfined system in the alluvium (surface mantle soils) of the Burro Flats area and along the major drainage channels. The alluvium is composed of a heterogeneous mixture of gravel, sand, silt, and clay, which are known to have hydraulic conductivities ranging from 0.1 to $100 \mathrm{gal} / \mathrm{day} / \mathrm{ft}^{2}$. Water levels in the alluvium respond to recharge resulting from precipitation and runoff, and may vary considerably between wet and dry periods.

The Chatsworth formation is composed of well consolidated, massively bedded sandstones with interbedded layers of siltstone and claystone. The formation may be as thick as $6,000 \mathrm{ft}$ at the SSFL site. The regional direction of groundwater flow in the formation is probably radially offsite toward the surrounding lowlands. The permeability of the Chatsworth formation is very low except along open fractures. Groundwater within the fractured Chatsworth formation occurs mostly under confined conditions.

environ.doc 
The hydrogeologic environment at the SSFL site is a dynamic system. The groundwater system is recharged by precipitation and infilltration through fractures and from unlined ponds and drainage channels. Because of the meager rainfall in the area and the relatively large variability in annual precipitation, groundwater recharge is generally low and may vary greatly from year to year. Specific pathways of possible transport of contaminant-bearing groundwater along fracture zones are difficult to predict. Fracture zones vary widely in frequency and geometry. Water transmitting characteristics also vary from one location to the other as well as from one specific depth to another. Not all fractures are water bearing. Recharge over the area may also vary over both space and time.

The solvents found in the groundwater include trichloroethylene and its family of degradation products. The analyses results of the Area IV wells have been documented in the "Area IV (Phase III) Groundwater Investigation Report" prepared for Rocketdyne by Groundwater Resources Consultants, Inc., in December 1992, (Ref. 21) as well as in their 1997 Annual Report (Ref. 22).

Three existing areas of TCE contamination in groundwater in the northwest part of Area IV were monitored in 1997. These areas are shown in Figure 6-3, where areas of suspected contamination exceeding $100 \mu \mathrm{g} / \mathrm{L}$ are shown in black, and areas equal to or above $5 \mu \mathrm{g} / \mathrm{L}$ are shown as cross-hatched. The State action level for TCE is $5 \mu \mathrm{g} / \mathrm{L}$. The central occurrence may also extend laterally; however, no data are available because this area is located in inaccessible terrain. The installation of twelve new monitor wells in 1993-1994 did not result in the detection of offsite plumes of degraded groundwater near Area IV.

The Shallow Zone well RS-28, one of the two wells within the TCE occurrence associated with the RMHF canyon (the northern occurrence), recorded $34 \mu \mathrm{g} / \mathrm{L}$ TCE in May 1996. The other well, a Chatsworth formation well (RD-30) showed 12 to $18 \mu \mathrm{g} / \mathrm{L} \mathrm{TCE}$ in 1997. Both wells were installed in 1989. RD-34A, a Chatsworth formation well (shallowest well of a threewell cluster constructed in 1991), in the newly acquired land showed 5.1 to $5.6 \mu \mathrm{g} / \mathrm{L}$ TCE in 1997, compared to 5.8 to $9.8 \mu \mathrm{g} / \mathrm{L}$ in 1996. RD-63, an extraction well installed in 1994 for the pilot extraction test in the area, recorded 7.3 to $8.6 \mu \mathrm{g} / \mathrm{L}$ TCE in 1997.

The Chatsworth formation well (RD-7), within the central contaminated area (Figure 6-3) southwest of 4059 , recorded a TCE concentration of 42 to $53 \mu \mathrm{g} / \mathrm{L}$ in 1997 compared to 38 to 51 $\mu \mathrm{g} / \mathrm{L}$ in 1996 . Since its construction in $1986, \mathrm{RD}-7$ generally showed TCE concentrations in the 16 to $53 \mu \mathrm{g} / \mathrm{L}$ range with peaks ranging up to $130 \mu \mathrm{g} / \mathrm{L}$.

RD-25, located southwest of 4059, continued to show perchloroethene (PCE). In 1997, the well showed 23 to $28 \mu \mathrm{g} / \mathrm{L} \mathrm{PCE}$, compared to 27 to $29 \mu \mathrm{g} / \mathrm{L} \mathrm{PCE}$ in 1996 . From 1989 to 1995 , the well showed less than 1 to $42 \mu \mathrm{g} / \mathrm{L}$ PCE.

Two Shallow Zone wells (RS-18 and RS-54) of the southern contaminated area (Figure 63) near the FSDF at the western end of the site, recorded a significantly high TCE concentrations 
from 1993 to 1996 . TCE in RS-54 ranged from 2,100 to $4,500 \mu \mathrm{g} / \mathrm{L}$ during the period from 1993 to 1996 . In 1997, TCE concentration ranged from 1,900 to $2,300 \mu \mathrm{g} / \mathrm{L}$. RS-18, often dry since its construction in 1985, recorded TCE at $540 \mu \mathrm{g} / \mathrm{L}$ to $3,200 \mu \mathrm{g} / \mathrm{L}$ in during the period from 1993 to 1996. RS-18 recorded $270 \mu \mathrm{g} / \mathrm{L}$ TCE in 1997. RD-21 and RD-23, two Chatsworth formation wells installed in 1989 at the FSDF, recorded TCE ranging from 88 to $2,200 \mu \mathrm{g} / \mathrm{L}$ during the period from 1993 to 1996 . In 1997, TCE in these wells ranged from 210 to $2,400 \mu \mathrm{g} / \mathrm{L}$. RD33A, Chatsworth formation well (shallowest well of a three-well cluster constructed in 1991), showed 7.5 to $9.7 \mu \mathrm{g} / \mathrm{L}$ TCE in 1997 , compared to 2.4 to $9.5 \mu \mathrm{g} / \mathrm{L}$ in the period from 1993 to 1996. RD-65, a Chatsworth formation well located northeast of the FSDF showed 67 to 610 $\mu \mathrm{g} / \mathrm{L} \mathrm{TCE}$ in 1997. TCE in the well was between 61 and $150 \mu \mathrm{g} / \mathrm{L}$ in 1996.

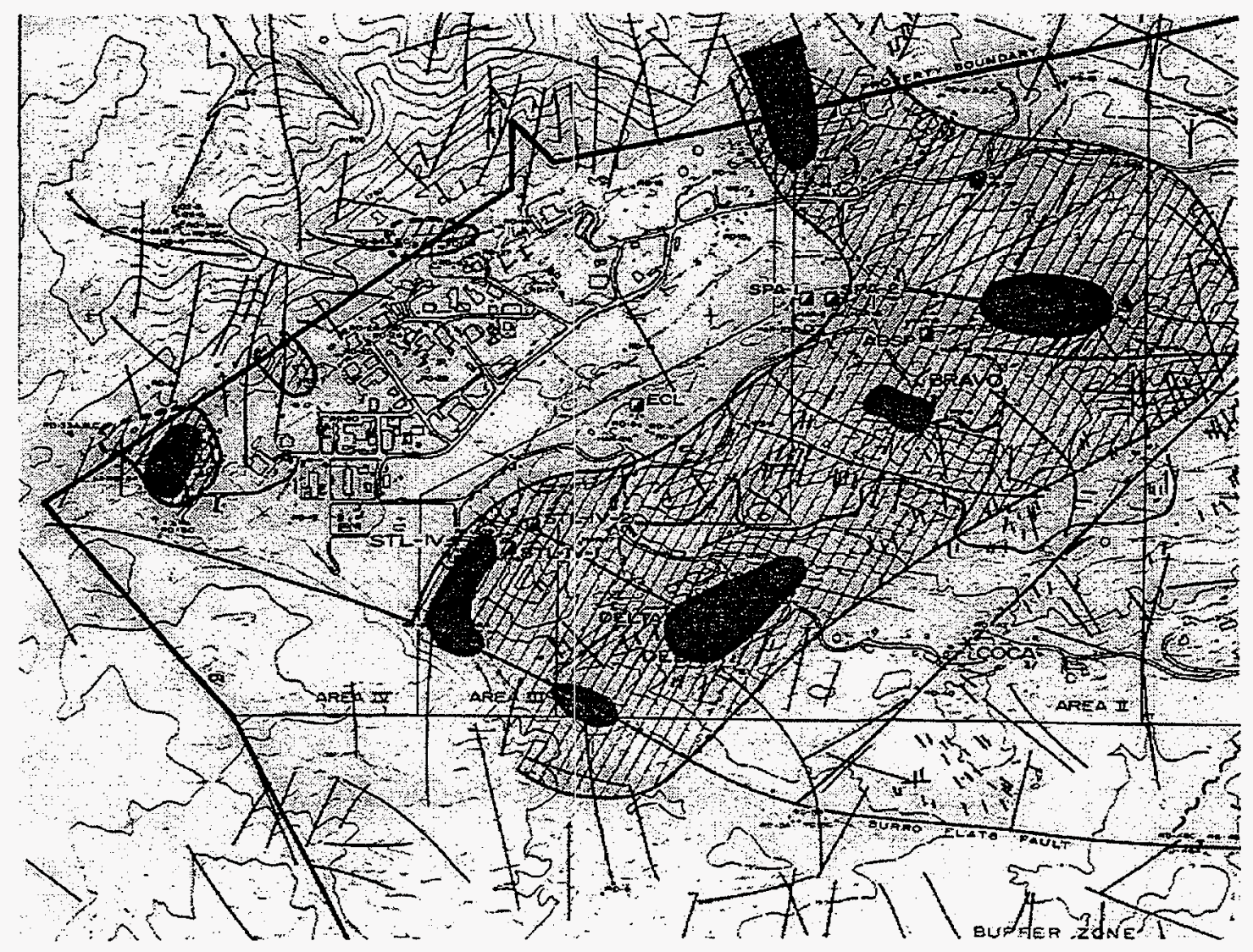

Figure 6-3. TCE Occurrences in Groundwater at SSFL, Area IV 
The pilot extraction test at RMHF included installation of an extraction well, and treatment of the extracted water in a portable carbon adsorption treatment unit. Results indicated that groundwater extraction in the test well at RMHF was effective in creating a capture zone for degraded groundwater. The capture zone extended up to $200 \mathrm{ft}$ down gradient of the extraction well. Two new wells were installed for the pilot test at the FSDF. Cyclic pumping of one to three wells was conducted in the test at this site, an area characterized by low yield of groundwater. Extraction and treatment of contaminated groundwater continued on an interim basis at RMHF and the FSDF in 1997. Groundwater from both sites is treated by liquid-phase carbon adsorption and is released southward to the surface water collection system. The activity at the FSDF was initiated in 1994 and at the RMHF in 1997. 


\section{ENVIRONMENTAL MONITORING PROGRAM QUALITY CONTROL}

This section describes the quality assurance (QA) elements that are incorporated into the Rocketdyne radiological analysis program to ensure that data produced are as meaningful as possible.

The following elements of quality control are used for the Rocketdyne program:

1. Reagent Quality - Certified gracle counting gas is used.

2. Laboratory Ventilation - Room air supply is controlled to minimize temperature variance and dust incursion.

3. Laboratory Contamination - Periodic laboratory contamination surveys for fixed and removable surface contamination are performed. Areas are cleaned routinely and decontaminated when necessary.

4. Control Charts - Background and reference source control charts for counting equipment are maintained to evaluate stability and response characteristics.

5. Laboratory Intercomparisons - Kocketdyne participates in the DOE EML-QAP.

6. Calibration Standards - Counting standard radioactivity values are traceable to NIST primary standards.

7. Co-location of State DHS thermoluminescent dosimeters.

\subsection{PROCEDURES}

Procedures followed include those for sample selection; sample collection; packaging, shipping, and handling of samples for offsite analysis; sample preparation and analysis; the use of radioactive reference standards; calibration methods and instrument QA; and data evaluation and reporting.

\subsection{RECORDS}

Records generally cover the following processes: field sample collection and laboratory identification coding; sample preparation method; radioactivity measurements (counting) of samples, instrument backgrounds, and analytical blanks; and data reduction and verification.

Quality control records for laboratory counting systems include the results of measurements of radioactive check sources, calibration sources, backgrounds, and blanks, as well as a complete record of all maintenance and service.

Records relating to overall laboratory performance include the results of analysis of interlaboratory cross-check samples and other quality control analyses; use of standard (radioactive) reference sources; and calibration of analytical balances. 


\subsection{QUALITY ASSURANCE}

Rocketdyne participates in the DOE Quality Assessment Program (QAP) operated by the Environmental Measurements Laboratory (EML) in New York for radiological analyses. During 1997, two sets of samples were distributed: QAP-XLVI and QAP-XI VII (Refs. 15 and 16). In 1994, EML analyzed the QAP historical data for air filter, soil, vegetation, and water samples from 1982 through 1992 to generate representative control limits for the performance evaluation of analytical services. The individual data values reported by the participating laboratories were normalized to the EML reference value, and the normalized values were grouped into percentiles. The middle $70 \%$ of all historical reported values (from the 15 th to 85 th percentile) was established as Acceptable and the next $10 \%$ on both sides of the 70\%-the 5th to 15th and 85th to 95th percentiles--as acceptable with Warning. Results outside this $90 \%$ band were considered not acceptable.

Results of Rocketdyne (RD), Teledyne-Brown Engineering Environmental Services (TB), and the DHS analyses, and the average for all laboratories, are shown in Figure 7-1 for QAP-XLVI and QAP-XIVII. (DHS results for QAP-XIVII were not reported in the program documents.) Although these comparisons involve sample types, geometries, and analyses that are not part of the routine procedures at the Rocketdyne laboratory, historical review of the Rocketdyne results and those of the other laboratories has generally shown a similar level of quality. This remains the case for the present results for water samples for QAP-XLIV and QAP-XLV, and for soil and vegetation samples for QAP-XLV.

The QAP soil and vegetation samples (200 $\mathrm{g}$ and $100 \mathrm{~g}$, respectively) are significantly smaller than the typical $600 \mathrm{~g}$ sample size used at Rocketdyne for similar analyses. In 1996, Rocketdyne succeeded in modifying the small amounts of soil, vegetation and water samples provided by the EML so that geometric effects had negligible impact on the analytical results. In 1997, Rocketdyne improved the air sample results over previous analyses. Note, however, that Rocketdyne conducts no quantitative air filter analyses for environmental use. All quantitative environmental air samples for the site are analyzed by outside laboratories. For the present report, soil samples and air and effluent filters were analyzed by Teledyne-Brown (Westwood, NJ). 
Figure 7-1. Quality Assessment Program Results for QAP-XLVI and QAP-XLVII

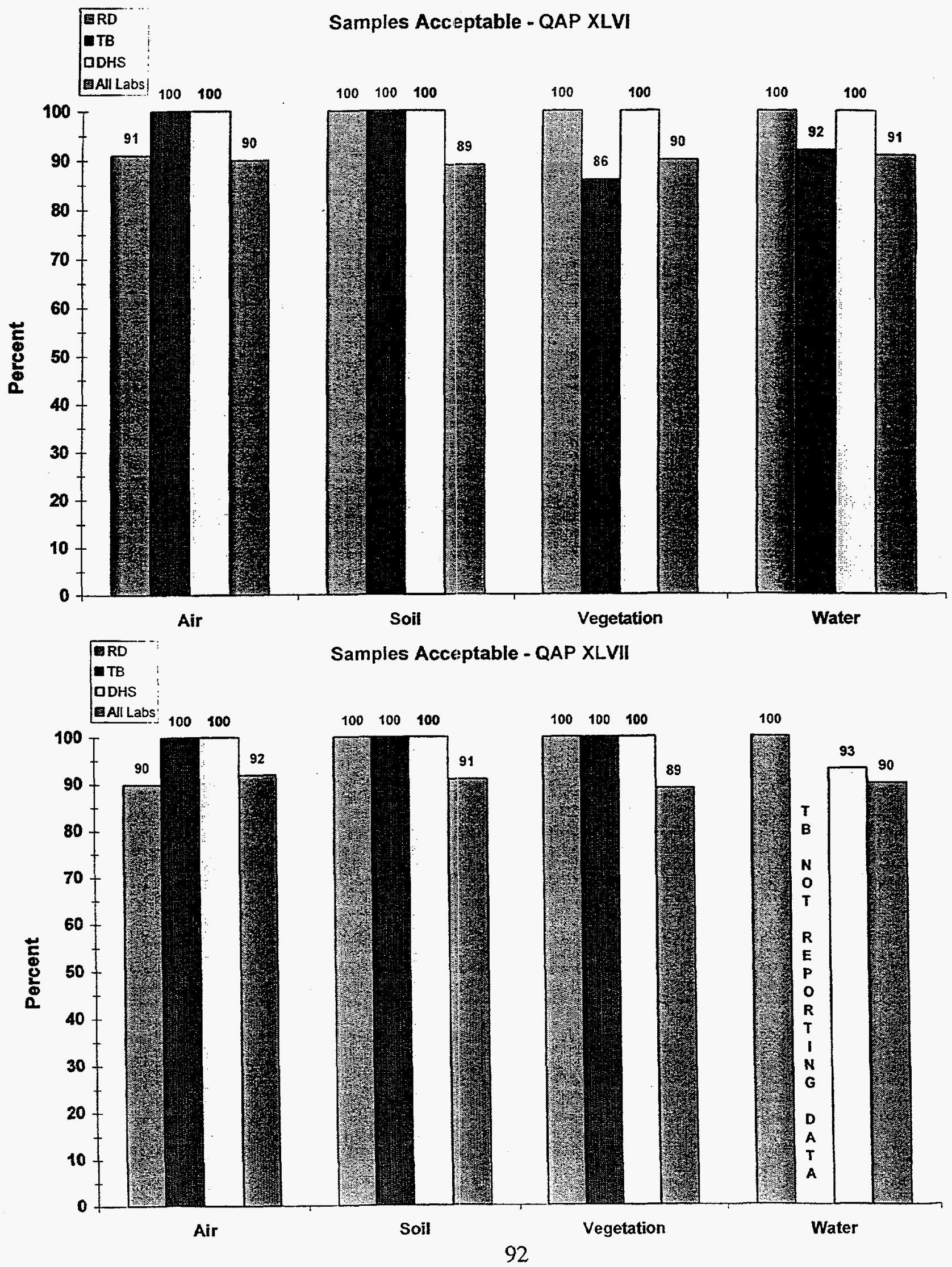


This page intentionally left blank. 


\section{REFERENCES}

1. R. D. Oldenkamp and J. C. Mills, "Nuclear Operations at Rockwell's Santa Susana Field Laboratory - A Factual Perspective," Rockwell Document N001ER000017, Rev. C, September 1991.

2. F. C. Dahl and R. J. Tuttle, "Final Radiological Survey Report of Building 023", Rockwell Document 023-ZR-0001, March 1994.

3. F. C. Dahl, "Final Radiological Survey Report of Building 4064 Interior", Rockwell Document SSWA-ZR-0001, February, 1994.

4. B. M. Oliver, "Final Radiological Survey Report for Building T012," Rockwell Document 012-AR-0002, June 1996.

5. A. L. Pascolla, "Decontamination and Decommissioning of Building T012," Rockwell Document 012-AR-0001, May 1997.

6. V. C. Chaney, "Final Radiological Survey Report for Building T363," Rockwell Document SSWA-AR-0002, June 1996.

7. T. J. Vitkus and J. R. Morton, "Verification Survey of Building T012, Santa Susana Field laboratory, Rockwell International, Ventura County, California," ORISE 96-0860, October 1996.

8. T. J. Vitkus and J. R. Morton, "Verification Survey of Building T363, Santa Susana Field Laboratory, Rockwell International, Ventura County, California," ORISE 96-0870, October 1996.

9. Users Guide for CAP88-PC, Version 1, EPA/520/6-91-022, December 1991

10. EPA 520/1-89-003, “User's Guide for the COMPLY Code," U.S. EPA, October 1989.

11. Groundwater Resources Consultants, Inc., "Annual Groundwater Monitoring Report, Santa Susana Field Laboratory, 1996," Tucson , Arizona, February 26, 1997.

12. H. Morganstern, et. al., "Epidemiologic Study to Determine Possible Adverse Effects to Rocketdyne/Atomics International Workers from Exposure to Ionizing Radiation," June 1997.

13. M. Pollycove, "Rocketdyne/Atomics International Worker Occupational Study - Critique," Presentation to the U.S. NRC Advisory Committee on Nuclear Waste, December 16,1997.

14. O. G. Raabe, "Health Physics Implications of the Rocketdyne Worker Study," Journal of the Health Physics Society, Supplement to Vol. 74, No. 6, June 1998.

15. C. Willis, "The Rocketdyne/Atomics International Radiation Epidemiology Study," http://rdeweb/shea/teams/radsafe/willis.htm

16. M. S. Ford, "A Report to the Texas Radiation Advisory Board on the Rocketdyne Worker Health Study \& Federal Guidance Report No. 13," May 8, 1998. 
17. DOE Order 5400.1, "General Environmental Protection Program Requirements," February 2, 1990.

18. DOE Order 5400.5, "Radiation Protection of the Public and the Environment," (2/8/90), Change $1(6 / 5 / 90)$, Change $2(1 / 7 / 93)$.

19. R. Atkinson, "ETEC Waste Minimization and Pollution Prevention Awareness Plan," ETEC Document GEN-AN-0037, Rev. A, September 1996.

20. C. Yu et al., "Manual for Implementing Residual Radioactive Material Guidelines Using RESRAD, Version 5.0," ANL/EAD/LD-2, September 1993.

21. Groundwater Resources Consultants, Inc. "Area IV Groundwater Investigation Report," December 1992.

22. Groundwater Resources Consultants, Inc., "Annual Groundwater Monitoring Report, Santa Susana Field Laboratory, 1997," Tucson, Arizona, February 25, 1998.

23. EML-587, "Semi-Annual Report of the Department of Energy, Office of Environmental Management, Quality Assessment Program," USDOE Report, January 1997.

24. EML-591, "Semi-Annual Report of the Department of Energy, Office of Environmental Management, Quality Assessment Program," USDOE Report, July 1997. 


\section{APPENDIX A \\ ACRONYMS}

ACM

AI

ALARA

ANL

AOC

ASL

BOD

CAA

CCR

CERCLA

CFR

$\mathrm{CO}$

COD

CRWQCB

CWA

CX

D\&D

DCG

DHS-RHB

DOE

DS

DTSC

EA

ECL

EIS

EM

EP

EML

EPA

ER

ETEC

ETS

FFCA
Asbestos-Containing Materials

Atomics International

As Low As Reasonably Achievable

Argonne National Laboratory

Areas of Concern

Above Sea Level

Biological Oxygen Demand

Clean Air Act

California Code of Regulations

Comprehensive Environmental Response, Compensation, and Liability Act

Code of Federal Regulations

Carbon Monoxide

Chemical Oxygen Demand

California Regional Water Quality Control Board

Clean Water Act

Categorical Exclusion

Decontamination and Decommissioning

Derived Concentration Guide

Department of Health Services-Radiologic Health Branch

Department of Energy

De Soto Facility

Cal-EPA Department of Toxic Substances Control

Environmental Assessment

Effluent Concentration Limit

Environmental Impact Statement

Environmental Management

Environmental Protection

Environmental Measurements Laboratory

Environmental Protection Agency

Environmental Remediation

Energy Technology Engineering Center

Extraction and Treatment System

Federal Facilities Compliance Act 
FONSI

FSDF

GRC

HEPA

Hot Lab

HWMF

IVC

LADWP

LAFD

LARWQCB

LLTR

LLW

LMDL

MCL

MDA

MPC

NA

ND

NEPA

NESHAPS

NIOSH

NIST

NOI

NOV

NOx

NPDES

NRC

NSPS

ODS

ORISE

PA/SI

PCB

PCE

PNNL

QA

QAP

RA
Finding of No Significant Impact

Former Sodium Disposal Facility

Groundwater Resources Consultants, Inc. (Tucson, AZ)

High-Efficiency Particulate Air

Hot Laboratory (4020)

Hazardous Waste Management Facility

Independent Verification Contractor

Los Angeles Department of Water and Power

Los Angeles Fire Department

Los Angeles Regional Water Quality Control Board

Large Leak Test Rig (4059)

Low Level Waste

Liquid Metal Development Laboratory

Maximum Contamination Level

Minimum Detectable Activity

Maximum Permissible Concentration, air, or water

Not Analyzed or Not Available

Not Detected

National Environmental Policy Act

National Emission Standards for Hazardous Air Pollutants

National Institute of Occupational Safety and Health

National Institute of Standards and Technology

Notice of Intent

Notice of Violation

oxides of nitrogen

National Pollutant Discharge Elimination System

Nuclear Regulatory Commission

New Source Performance Standards

Ozone Depleting Substance

Oak Ridge Institute for Science and Education

Preliminary Assessment/Site Investigation

Polychlorinated Piphenyl

Perchloroethene

Pacific Northwest National Laboratory

Quality Assurance

Quality Assessment Program

Radioactive 
$\mathrm{RD}$

R\&D

RCRA

RFA

RFI

RMDF

RMHF

ROD

RPT

SABER

SARA

SCAQMD

SCTI

SCTL

SHEA

SNAP

SNM

SPCC

SRE

SSFL

SWPPP

STP

SWMU

TB

TCE

TLD

UCLA

UST

VCAPCD

VCEHD

VOC

WVN
Rocketdyne

Research and Development

Resource Conservation and Recovery Act

RCRA Facility Assessment

RCRA Facility Investigation

Radioactive Materials Disposal Facility

Radioactive Materials Handling Facility

Record of Decision

Reaction Products Tark

Steam Accumulator Blowdown Evaluation Rig

Superfund Amendments and Reauthorization Act

Southern California Air Quality Management District

Sodium Component Test Installation

Small Component Test Loop

Safety, Health, and Environmental Affairs

Systems for Nuclear Auxiliary Power

Special Nuclear Materials

Spill Prevention Control and Countermeasure

Sodium Reactor Experiment

Santa Susana Field Laboratory

Storm Water Pollution Prevention Plan

Sewage Treatment Plant or Site Treatment Plan

Solid Waste Management Unit

Teledyne Brown Engineering

Trichloroethylene

Thermoluminescent Dosimeter

University of California, Los Angeles

Underground Storage Tank

Ventura County Air Pollution Control District

Ventura County Environmental Health Division

volatile organic compound

Water Vapor Nitrogen 


\section{DISTRIBUTION}

\section{(single enclosure unless otherwise noted)}

U.S. Department of Energy

Office of Scientific and Technical Information

P.O. Box 62

Oak Ridge, TN 37831

H. Joma (4 copies)

DOE/ETEC Site Manager

Oakland Operations Office

U.S. Department of Energy

Energy Technology Engineering Center

P.O. Box 7929, Canoga Park, CA 91309

U.S. Department of Energy

Environmental Measurements Lab

201 Varick Street, Fifth Floor

New York, NY 10014-4811

Steve Black (8 copies)

U.S. Department of Energy Oakland

Operations Office

1301 Clay Street, Suite 700-N

Oakland, CA 94612

County of Ventura

Fire Protection District

Hazardous Material Section

395 Willis Avenue

Camarillo, CA 93010

County of Ventura

Resource Management Agency

Ventura, CA 93009

Ventura County Board of Supervisors

800 South Victoria Blvd.

Ventura, CA 93009

U.S. Environmental Protection Agency

Regional Radiation Representative

Region 9

75 Hawthorne Street

San Francisco, CA 94105

Tom Kelly

U.S. Environmental Protection Agency

Region 9

75 Hawthorne Street

San Francisco, CA 94105
Gregg Dempsey

Center for Environmental Restoration, Monitoring and Emergency Response

U.S. Environmental Protection Agency

944 E. Harmon Street

Post Office Box 98517

Las Vegas, NV 89193

Ed Bailey

California State Department of Health

Services

Radiologic Health Branch

714 "P" Street

Sacramento, CA 95201

Paul Baldenweg

California State Department of Health

Services

Radiological Health Branch

1449 West Temple Street, Room 209

Los Angeles, CA 90026

Jack McGurk

California State Department of Health

Services

Environmental Management Branch

714/744 "P" Street

P.O. Box 942732

Sacramento, CA 94232-7320

California State Department of Health

Services

Chief, Environmental, Epidemiology and

Toxicology Branch

2151 Berkeley Way

Berkeley, CA 94704

Phil Chandler

California Environmental Protection Agency

Department of Toxic Substances Control

Region 3

1011 North Grandview Avenue

Glendale, CA 91201 
Jim Ross

California Regional Water Quality Control

Board

Los Angeles Region

101 Centre Plaza Drive

Monterey Park, CA 91754-2156

Los Angeles County Health Department

Occupational Health and Radiation

Management

Los Angeles, CA 90007

U.S. Nuclear Regulatory Commission

Office for Analysis and Evaluation of

Operational Data

Washington, DC 20555

Richard Turtil

Low Level Waste \& Decommissioning

Division of Waste Management

Office of Nuclear Material Safety \&

Safeguards

U.S. Nuclear Regulatory Commission

Washington, DC 20555-0001

U.S. Nuclear Regulatory Commission

Division of Radiation Safety \& Safeguards

Attention: J. J. Collins

611 Ryan Plaza Drive, Suite 400

Arlington, TX 76011

Paul Fox

American Nuclear Insurers

Town Center, Suite 3005

29 Main Street

West Hartford, CT 06107-2445

City Manager of Simi Valley

2929 Tapo Canyon Road

Simi Valley, CA 93063

California State University, Northridge

Attn: Robert Marshall

Urban Archives Center

Oviatt Library - Basement, Room 4

18111 Nordhoff Street

Northridge, CA 91330
Simi Valley Public Library

Attention: Ms. Janet Weaver

2969 Tapo Canyon Road

Simi Valley, CA 93063

Platt Branch Library

Attn: Ms. Janet Metzler

23600 Victory Blvd.

Woodland Hills, CA 91367

The Honorable Cathie Wright

California State Assembly

District 37

250 Easy Street, Suite 7

Simi Valley, CA 93063

The Honorable Elton Gallegly

United States House of Representatives

21st District

9301 Oakdale Avenue \#110

Chatsworth, CA 91311

Dan Hirsch

Committee to Bridge the Gap

1637 Butler Street

Los Angeles, CA 90027

Sheldon Plotkin

3318 Culbert Avenue

Los Angeles, CA 90066

Barbara Johnson

6714 Clear Spring Road

Simi Valley, CA 93063

Jerome Raskin

18350 Los Alimos Street

Northridge, CA 91326

Santa Monica Mountains Conservancy

Authority

Attn: Rorie Skei

3750 Solstice Canyon Road

Malibu, CA 90265

Arthur Pinchev

Brandeis-Bardin Institute

1101 Pepper Tree Lane

Simi Valley, CA 93064 